
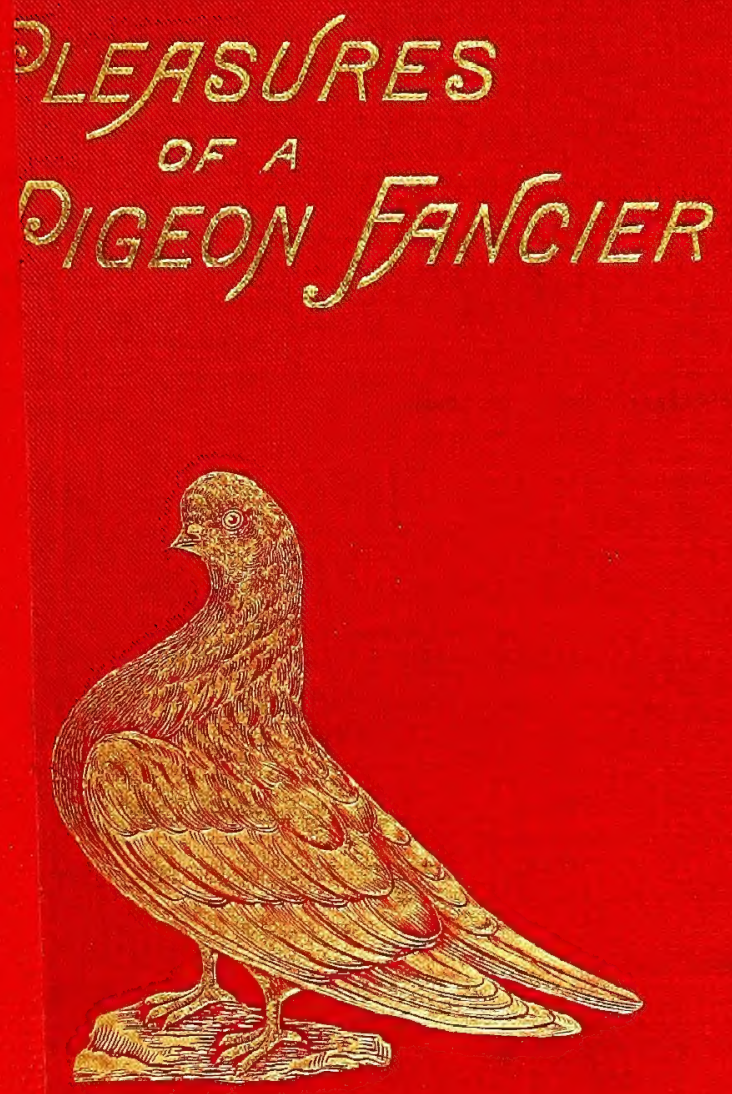

V. J.LUCAS. 


\section{ALBERT R. MANN LIBRARY \\ New York State Colleges OF}

Agriculture and Home Economics

AT

CORNELI UNIVERSITY

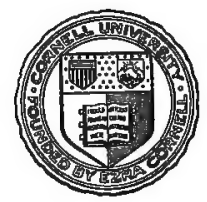

THE GIFT OF

Paul Pomeroy Ives 2D

IN MEMORY OF

PAUl Pomeroy IVES 


\section{SF 465.193}

The pleasures of a pigeon-fancier.

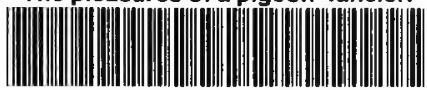

3 1924000084099 mann 


\section{Cornell University Library}

The original of this book is in the Cornell University Library.

There are no known copyright restrictions in the United States on the use of the text. 



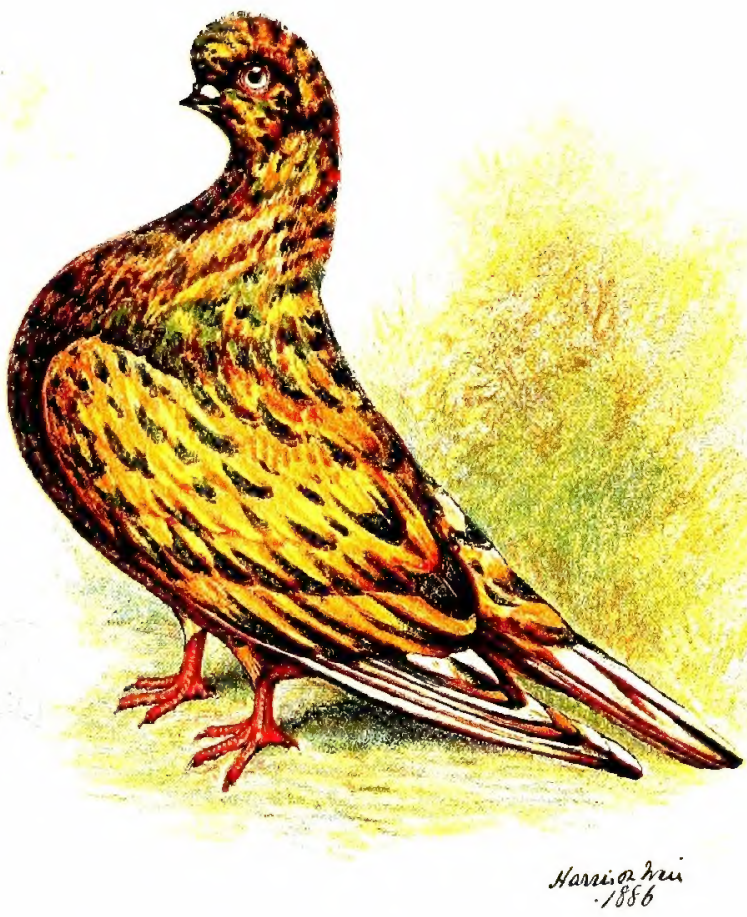

The Almond Tumbler. 


\title{
THE PLEASURES
}

\author{
OF A

\section{P I G E O N - F A N C I E R.}

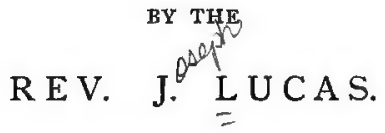

LONDON :

SAMPSON LOW, MARSTON, SEARLE, \& RIVINGTON, CROWN BUILDINGS, I88 FLEET STREET.

1886.

[All rights reserved.]

HCT 


\section{$5 F$ \\ 465 \\ $\angle 93$ \\ E 6528}

PRINTED BV BALLANTYNE, HANSON AND CO. EDINBURGH AND LONDON. 


\section{Dedicate tbis JBO0k (BY PERMISSTON)}

TO

\section{FOHN RUSKIN, EsQ.,}

WHO HAS TAUGHT ME TO SEE BEAUTY IN EARTH AND SEA, MOUNTAINS AND CLOUDS, IN FLOWERS AND BIRDS, AND GOD IN EVERYTHING. 



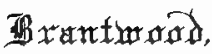

Cintaton, 近ancastixts.

28 Zune 86

My cear fir

I shall h quatepul for the dedication of you books and an haffy in all por erparmoin of Kaid feeley I wis d concel hae dore thos pigran for you. Beleion me Faithficlf Jom loku Raskin 





\section{P R E F A C E.}

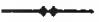

THIS book is the offspring of my leisure hours. It is not a treatise on Pigeons compiled on scientific principles. It is an essay. An essay should be chatty rather than systematic, so that you can wander off into by-ways that attract the fancy without transgressing. There are points of interest that might have been touched on, such as the descent of all Pigeons from one common ancestry. But this wide field of discussion has been so well ploughed by scientific hands, that I declined to enter upon it. It is harrowing work to rake among other people's stale thoughts when you have no fresh ones to add yourself. To Messrs. Fulton, Gellett, and Woodhouse, my best thanks are due for assistance rendered.

September 27, 1886. 



\section{CONTENTS.}

CHAP.

PAGE

I. THE PLEASURE OF THE FANCY . * . I I

II. THE ART OF THE FANCY . . . . I4

III. THE PEDIGREE OF THE FANCY • . . 23

IV. THE CONFESSIONS OF A FANCIER . . . $4 \mathrm{I}$

V. THE DUTIES OF A FANCIER . . . . 58

VI. A CAUTION TO FANCIERS • • . . 65

VII. THE FAVOURITES OF THE FANCY-

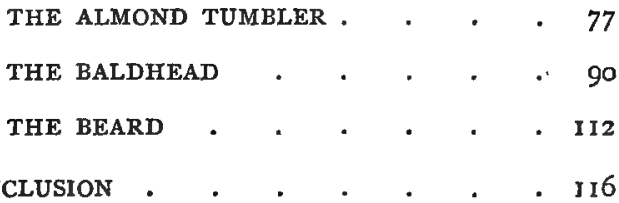

INDEX $. \quad+\quad . \quad+\quad . \quad$ - 120 


\section{LIST OF ILLUSTRATIONS.}

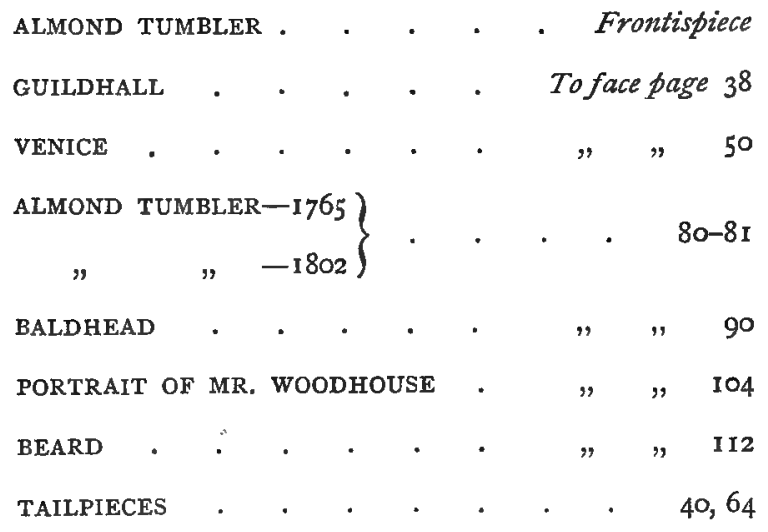




\section{THE PLEASURES OF A PIGEON- FANCIER.}

CHAPTER I.

THE PLEASURE OF THE FANCY.

"Mankind," says one who has written on the History of Fiddles, "Mankind may be divided into two classes-those who play the violin and those who do not." Our author, observing that the former class constitute the minority (the select and prescient few), says of the latter, that is, the herd of men, with a lofty yet benevolent contempt, "Let them not despair. They cannot all hope to play the fiddle. If they respect, admire, and encourage those who do play it, that is perhaps sufficient."

The same sharp line of demarcation can be pronounced by those who write on the History of Pigeons. Mankind may be divided into two 
classes - those who keep pigeons and those who do not. The former class in "our fancy," as in the fiddling fraternity, constitute the minority. Are not all aspirants after human excellence in the minority? And the Pigeon-Fancier, from his happy vantage-ground, surveys with sublime and pitiful contempt the hapless ignorance of the vast crowd of human beings who have never bred a bird, and who cannot tell the difference between a Carrier and a Barb, a Baldhead and a Runt. It is lamentable to think that their education has been so seriously neglected! Let them not despair! If they look upon and admire the surpassing loveliness of other people's birds, and purchase them, perhaps that is all that can be expected of them.

I am thankful that I early in life found a place amongst the superior and enlightened few who love the birds for their own sake, and keep them because of the pure and unmixed gratification they afford me. Why do I love Pigeons? I cannot tell. Other people do not care for them. Why do I ? I puzzle my brains and get no satisfactory reply to my inquiry. I suppose the love of them came to me intuitively and abides with me permanently. The apple-tree might just as curiously question why apple blos- 
soms come on it in the springtime. Who that has an eye for beauty can look upon an Almond Tumbler, that tame and graceful creature, the pet of the fancy, apparelled sumptuously in richhued plumage, and watch the lustre of amethyst, bathed in emerald, quivering on its shining neck as it struts about with proud, imperious carriage-who can thus observe it without the splendour of the display evoking an exclamation of delight? Written legibly all over the resplendent plumage of the bird is this broad teaching, which a reverently observant eye can instantly detect, the love of God shown in the loveliness of His works. The Creator stamps His gifts to man with His own seal, and His seal is Beauty. Everything in nature is beautiful. And are we to receive into our heart the gross and treasonable theory of Darwin, that when the Creator was furnishing a world for man to dwell in $\mathrm{He}$ did not consult the tastes of the occupants?-that all the beautiful drapery of the sky, and the floral carpeting of the earth, and the decorative feather of the bird, came to them by chance, or by the "agency of selection," to clothe the bald idea in biological language?

Take, for instance, the Sky. The material use and end of the sky is to collect and distil 
the vapours of the earth in the gentle dew and genial shower, and pour down upon the fields those fertilising streams which are the life of vegetation, and consequently the life of man and beast. Could not this be accomplished in some uninteresting, unbeautiful, and even repulsive manner? The Creator might have stretched over us great black clouds, and caused them to empty themselves in a monotonous drizzle, and after their work was done $\mathrm{He}$ might make the manner of their removal as revolting to our feelings. But now see the beauty and the splendour of their handling! See the clouds in the morning when they bar up the road of the merry sun and ask for his passage a toll of gold! See them at night when they trip up the feet of the nimble moonbeams and detain the silver huntress from the chase! See them on a bright summer afternoon loitering as fancy leads them in lightsome groups across the vault of blue! And see them on an autumnal evening burning in fiery splendours, yet not consumed, as the sun sinks on the western horizon, crimsoning the earth and the heavens with the reflection of their fiery glory, and ask yourself, as you watch the beauty in their formation and the poetry in their movements, whether it all means nothing, 
simply the fortuitous production of the laws of nature?

Take the Flowers also. Are they not incomparably beautiful, as they tessellate the earth with a wealth of colour and cunning diversity of design? A plainer vesture might have answered every material purpose of the flower's creation. There was no necessity for that blaze of colour if its only 'office was to feed the cattle or manure the soil. A common garment would have done for these common purposes. But because it was an ordained minister of God to appeal to the higher faculties of man, and bear its royal witness to the King of human hearts and lives, therefore was it clothed with a courtier's robes, and decked with the honours of heaven's ambassador.

Is a Bird lower in the scale of creation than a flower-or is its beauty less eloquent? Those Pigeons that I look upon every day-are their magnificent markings wasted beauty, or the pencillings of a Divine Artist? I believe there is a religious side to Nature as well as a material one. Besides existing to give us bread to eat and water to drink and raiment to put on, she gives us food for thought and fuel for worship and beauty for admiration. If you want a revela- 
tion from God, Mr. Fancier, on the week day when church doors are locked and bolted on the public, go into your own loft and look around and think. The Revelation is there, if you have eyes to see, and heart to appreciate.

- My Pigeons yield me annually a bountiful crop of pure, innocent, and quiet enjoyment. When in the aviary surrounded by my birds, with all vain thoughts of the rivalry of the show-pen out of mind, and all sordid thoughts of the competition of the Auction Mart equally distant, I enjoy myself. Time passes pleasantly taking up this bird, admiring that one, reviewing the good points of this squeaker, and meditating the best match for that new purchase. On a warm summer afternoon I sit on the garden seat in front of the "flight" with one of Ruskin's books in my hand, having one eye on the book and the other eye on the birds. Presently I abandon the book altogether as a useless subterfuge, and lie full stretch on the grass in the cool shadow under the leafy poplars watching the birds merry at play, happy at lovemaking, preening their lustrous feathers or lying restful in the sunshine.

Do you say enjoyment is not an exalted object in life to pursue? Enjoyment is as 
necessary to our well-being as Duty-Recreation is as healthful as Work. Charles Kingsley said, "If you have not something to enjoy in life you are a living grave." In a small quaint black-letter book I own, printed I552, called "The Christian State of Matrimonie" (I love books as well as birds), the author, Miles Coverdale, says, "God did intend man to be happy, for when $\mathrm{He}$ created him $\mathrm{He}$ put him in the Paradise, that is the garden of pleasure." Now all the world over, a garden with its luscious fruits and fragrant flowers and springing fountains, is typical of happiness. And man, ever since he was ousted from that Garden of Pleasure, has been trying to plant another garden of his own fashioning, where he may dwell, lapped in enjoyment and ambrosial rest. We all want our Eden! Some people attempt to plant theirs amidst the glitter and gaiety of the fashionable world, but the atmosphere is uncongenial, and their garden withers into a wilderness. They build their mansions and they open their Picture Galleries, and they summon Prima Donnas, and they offer every inducement to happiness to come and live there, but happiness will not come. They send footmanned and postillioned equipage to bring her; she will 
not ride to their door. They send princely escort; she will not take their arm. They make their gateways triumphal arches; she will not ride under them. They upholster sumptuously their withdrawing rooms; she will not recline on their deep-cushioned lounges, nor show her face in their scintillating mirrors. They spread a costly banquet on golden plate; she turns away from their festivity with unmitigated disgust!

Their search after happiness cannot be considered a success. There may be pleasure in the chase, but they are baffled at the end, because where they hunt, the covers are empty. The secret is, men bid too high for their enjoyment; they fallaciously conclude the more it costs the more delectable it must be. The truth lies at the opposite pole. Real pleasure is found in simple things. The heart easiest satisfied is the happiest heart. Ruskin says of his old friend and first Editor, Mr. Harrison, "He was an object to me of quite special admiration in the quantity of pleasure he could take in little things." Lord Rothschild paid $£ 50,000$ for two of the Marlborough pictures. Expensive toys! Will he extract $£ 50$,000 worth of quiet, profitable enjoyment out of his high art 
purchase? I fear not as much enjoyment as the Spitalfield's weaver gets out of his pigeons when he flies a kit of Rollers in the murky atmosphere of East London. There was too much of social rivalry and commercial competition in the Baron's big purchase for it to give an adequate supply of heart's-ease. It fed his pride-the pride of knowing that he had outbid the world, and snatched the prize from the wealthiest collectors. Pride is not happiness.

What a life of gilded misery old Stephen Girard the American millionaire led! Just before he died he wrote thus to a friend"I live like a galley-slave, constantly occupied, and often passing the night without sleep. I am worn out with cares. I do not value my fortune. When I rise in the morning my only effort is to labour so hard during the day that I may be able to sleep soundly at night." The poor rich man had no time for recreation. He was too busy to laugh. Life was solemn as a funeral march to him. He needed some hobby to come between him and his money-making to relieve his mind and refresh his body. A friend of mine, an old Fancier, during a pigeon chat said to me, "If I get worried in business during 
the day, and I often do, I come home in the evening and interest myself with the birds; I forget the day's trouble in their company, and so find a good night's sleep where other men would miss it."

I knew a blind man a Fancier. The birds and he were great friends and constant companions. He sat in his loft, and they alighted on his head, his shoulders, his knee. He could not see them, but he heard them. He would sit quietly thus for hours, the sun shining upon his sightless eyes and silvery head, surrounded by his feathered friends, listening to the flutter of their wings and the language of their cooing. He was content and joyous. If one of his children entered the loft they caught a bird, described it, and put it in father's hand. He fondled it a short time and let it go. Oh yes! our birds help to smooth from the crumpled countenance the lines of care; they lead our minds away from the fretful realm of strife. If life is monotonous, they provide a healthy diversion; if life is overwrought, they impart composure to it; instead of spending our leisure hours listlessly and stupidly, they furnish an intelligent and profitable pastime. They help to adjust the balance and keep the harp of life 
in tune. The poet in satirical verse has well lashed the follies of the age :-

"My heart is sad with sore misgiving, I think of days of auld lang syne;

The world was pleasant then to live in, And folks were neither fast nor fine.

" But everything is out of gear now, Such push and struggle, care and dread;

Of God on high we have no fear now, And down below the devil's dead;

" And things look crumbling all to ruin, So bleak, so dismal, were it not

For here some billing and there some cooing, What would there be to live for-what?"

I have spoken of the pleasure of the Fancy. Some persons keep pigeons whom I do not account Fanciers. They keep birds not for pleasure but for profit; and when the money question enters into the calculation, the love of the thing is bowed out. It assumes a business aspect at once. For instance, those who keep birds for racing. Horse-racing and pigeonracing I regard with equal abhorrence; not that it is impossible to follow each pursuit innocently. However, the stress of temptation is against it. Betting follows hard upon the heels of racing. I have heard high-faluting language about the "noble" Homer Pigeon-" training its intellectual powers;" but in nine cases out of ten the 
highly intelligent Homer is kept for the direct object of making money.

Others keep birds not to breed, but to barter. They buy birds as a speculator buys shares, meaning to sell again at a profit as soon as occasion offers. These are Pigeon-dealers. Although one or two dealers I could name know more about Pigeons than a tram-car full of amateurs; neither are these genuine Fanciers. What John Hill Burton in his delightful volume, "The Bookhunter," says concerning books, I say of Pigeons- "The mercenary spirit must not be admitted to a share in the enjoyments of the Bookhunter. If the Bookhunter allows moneymaking to be combined with his pursuit, it loses its fresh relish, its exhilarating influence, and becomes the source of wretched cares and paltry anxieties. . . . No good ever comes of gentlemen amateurs buying and selling."

With this exception: I can keep all my books, but I cannot keep all my Pigeons. They multiply rapidly and overstock my loft. I must dispose of some. I cannot do what a famous Book Collector with overstocked shelves didkeep my treasures under the bed! So whilst the wise Fancier gets instruction and pleasure from his pursuit, there is no reason why he 
should lose money by it. The amusement may chance to prove a very fine' investment. $\mathrm{He}$ has only to make his mark in the breed he has taken up, and he will seldom have cause to grumble at being overstocked. Mr. W. B. Tegetmeier, a Dragon-Fancier, never paid a higher price than $7 \mathrm{~s}$. $6 \mathrm{~d}$. for a bird, yet he has bred birds and sold them for as much as $\$ 25$ each. 
THE ART OF THE FANCY.

QuaINT Izaak Walton, whose book I dearly love, described angling as a "perfect art." It may be so. He adds, "It is an art worthy the knowledge and practice of a wise man." Perhaps there is a slight suspicion of egotism in what the charming old angler here asserts. Angling is the art of destroying life; PigeonFancying is the art of propagating life; and therein I maintain it lifts the crown from off the brow of angling, and places it upon its own meek and inoffensive head.

Pigeon-breeding is a consummate art. It has been tastefully and truly termed the cultivation of living flowers - the production of living pictures beautiful in form and rich in colour. The Fancier is an artist; and no artist has attained to perfection in the art. So there is better than a forlorn hope awaiting the young aspirants who have a mind to try their hand at 
the Fancy, and win their laurels in the showpen. The best bird has yet to be bred.

Lord Lytton says: "Man is so formed for design by the Great Designer that in his veriest amusement he still involuntarily seeks an object. He needs a something definite-a something that pretends to be practical, in order to rivet his attention." To impart a real lively zest, the Fancy sets before us a clearly defined object, which is to raise an ideal bird. Every PigeonFancier has an ideal of his own before him, and so has everybody else for that matter, if life be worth living. The farmer has his ideal cow; the artist an ideal picture he strives to paint; the business man has an ideal fortune he labours to amass; the preacher an ideal sermon he aspires to preach. Every young lady pictures the husband she prefers-kind, devoted, obedient, rich, docile, distinguished. Young men are equally shrewd, and can describe accurately the Angel-wrapt-in-clay they want for a wife-one who is domesticated as well as ornamentalone who is clever in the kitchen and accomplished in the drawing-room. May he get her: she is a rara avis.

The object of my leisure is to raise an ideal bird. I have selected a variety of the 
Tumbler, and I intend to introduce to the notice of the visitors at the Crystal Palace some November day the choicest bird of its class they have yet beheld. This is a difficult task to set out with. It requires an illimitable supply of patience, perseverance, and prudence to accomplish it. If the difficulty be surmounted I am satisfied, for Pigeon-Fancying like virtue is its own reward. Do not forget the three P's I have named-Patience, Perseverance, Prudence. You must invoke their aid constantly before producing your perfect specimen. Pigeon-Fancying is somewhat akin to poetrymen must be born to it. If you do not keenly relish the hobby, after a few disappointments you will abandon it. It is not every time the egg shells break open that a prize comes forth. There are numerous failures attending your efforts. But the man with patience eventually comes off triumphant. The young birds won't always hatch the paragons you pictured them. That lively squeaker you rely upon to do good service next season may thwart your purpose and die of canker in the meantime. Drink acquiescently these drops of bitterness in the Fancier's cup. The nonpareil is coming. It will be more appreciated when it does come 
through its arrival being delayed. Perhaps next year the unlikeliest pair in your loft will throw the peerless beauty you are in quest of. George Ure, the old and honoured Fancier, some of whose Pouters sold by auction last spring at over $£ 30$ a-piece, tells us how he climbed the ladder of fame. He says-

"I have striven for over twenty years and more to attain a property before I succeeded. You must make up your mind to grope in the dark for many years, getting a bird here and there that may look pretty well, but of which you know nothing, and therefore cannot tell the good or bad points most prominent in the strain. Perhaps you may by and by breed a good-looking bird or two-it would be strange if you did not-and they may gain a prize under a good judge. Do not, however, be in too great haste to call attention to your success by tooting on your own trumpet, for if the birds are bred in the haphazard style that I have referred to, you are sure to experience a backsliding-an unpleasant discovery-teaching that you have not yet reached the desired stage when 'like produces like' so frequently as to merit any claim to the possession of an established strain."

Learn the art of keeping a good bird when 
you possess it. Do not be bribed by gold to part with it. Stick to it. I knew a poor man who, often hard up, would sooner starve than sell his best birds. I admire him for his loyalty to his pets. He loves them better than money, and that is an uncommon characteristic in these degenerate days, when the only poetry a man admires he reads in the clatter of his horses' legs-

Dosn't thou 'ear my 'orse's legs as they canters awaäy?

Proputty, proputty, proputty-that's what I 'ears 'em saäy;

Proputty, proputty, proputty-Sam, thou's an ass for thy paains, Theer's moor sense $i$ ' one o' 'is legs nor in all thy braains.

Me an' thy muther, Sammy, 'as beän a talkin' o' thee;

Thou's been talkin' to muther, an' she beän a tellin' it me.

Thou'll not marry for munny-thou's sweet upo' parson's lass- *

Noä-thou'll marry for luvv-an' we boäth on us thinks tha an ass,

Seeä'd her to-daäy goä by-Saäint's-day - they was ringing the bells. She's a beauty, thou thinks-an soä is scoors $0^{\prime}$ gells,

Them as 'as munny an' all-wot's a beauty? the flower as blawsBut proputty, proputty sticks, an' proputty, proputty graws.

Walpole said "Every man has his price," but happily I know an exception to the rule. Guard your treasures as things too sacred for commerce. If not, you will never be a successful breeder. George Ure made it a rule never to sell a bird, whatever the price offered, if he thought he required it to improve his stock. Mr. Chapman, the famous Almond Tumbler. 
Fancier, adhered rigidly to the same rule. And if, after protracted chaffering, he did dispossess himself of a choice specimen to enrich the stud of a brother of the craft, he explained himself naively to a friend of mine, "You see, I have a better bird behind it now." So the purchaser never got what he covetedChapman's best bird. He parted with a good bird only when he had bred a better one.

Having spoken on the Art, the Artist also demands our attention. The Pigeon-Fancier is essentially a man of quiet, contemplative mind, for his work demands the constant action of thought, and the love of it compels the effort. Add to this the habits which one must fall into in being with the birds, the enforced calmness and gentleness, without which the best efforts are lost. Absorbed in his innocent pursuit, he dwells apart from the world of struggles and scandals, nor has he time to encourage the fungus growth of envy or malice in his own heart. Thus your artist in living pictures generally develops into a harmless member of society, living a gentle and kindly-mannered life. Mr. Ure says, "In the whole of my experience I never knew an instance of a real Fancier being a degraded or an immoral man." 
The Fancier is apt to be a vain man (I am impartial - so my censure will accredit my praise). He is vain of his success. Perhaps he may even give vent to a little brag on occasion. "Such and such a bird I bred won First at Birmingham and Cup at the Palace-it was the best bird of its variety ever seen." But who is hurt by his innocent self-assertion? Nobody. How very complacently he listens to welcome praise, and how well he persuades himself that he is perfectly modest and indifferent to all vanities - but we know that he is not.

Busying himself from day to day with things which the "superior person" regards disdainfully, the temptations of idleness are withdrawn from him, and whilst he is riding his hobby he gathers strength and freshness which enable him to grapple with the essential labours of life. All strong men who have moved in the world have had their hobbies. The great Earl Chatham, when weary of the Parliamentary hurly-burly, would retire to his gardens and woods at Hayes, and he was content to potter about among his roses all day long. Gladstone, great at work and great at play, mounts three hobbies. In London he hunts after old china; he is delighted as a school-boy with a new bat when a rare 
piece of "old blue" comes in his road. In the country he is an amateur woodman. $\mathrm{He}$ also has a "weakness" for Homer, and the minute problems connected with the style of the original blind bard. Metternich, the Austrian statesman, amused himself by keeping canaries, and he was as proud of his birds as he was of his most astute diplomatic feats. Cardinal Mazarin was great at jumping. Count Moltke is a chessplayer and novel reader. Ruskin collects minerals and jewels, and he has now a set worth $£ 30,000$, on which he prides himself more than he does on the Stones of Venice-the original MS. of which work he presented to a friend as " the memento of a wasted youth."

The Fancier's life is a long succession of expectations and fulfilments, and even when he meets with a disappointment, the change only gives a certain piquancy to his success. Let us imagine the awful case of a man beaten at a show, and let us shed a sympathetic tear! He has bestowed his keenest attention and fondest hopes on a certain young bird. He has watched its development from the nest. Look at its breadth of skull! What a magnificent stop it has! How beautifully the feathers are broken! $\mathrm{He}$ is sure that its good points must captivate 
the eye of the sternest judge. Alack-a-day, some insignificant rival beats him, and the world for an hour seems wholly a desolate place, a drear wilderness. It may be the unfortunate exhibitor would like to throw a few show pens at the winning rival. But in the ordinary run he ends by bestowing honest admiration on the victor, and sets to work with a view to meeting better luck next time.

The Fancier is usually a generous man, and is very partial to setting up young beginners with a few birds. He is proverbially a longlived man. His Fancy agrees with him. His habits are conducive to Iongevity-he generally dips well into the Seventies.

" What if his life's bloomy flush is lost, And his full autumn feels the mellowing frost? Yet time, who blowed the rose of youth away, Has left the vigorous stem without decay."

The Fancier is, par excellence, an enthusiast. Enthusiasm is the secret of success. It blinds him to the criticisms of the "superior persons" - these human beings are the bête noir of weakminded fanciers-and it makes him alive to the object he is working at, and fills him not with the desire only, but with the determination to do well the thing to which he has put his hand. 


\section{( 23$)$}

\section{CHAPTER III.}

THE PEDIGREE OF THE FANCY.

There is an opinion abroad that Pigeons are "low." It would be unkind to question the sanity of those persons who thus asperse the respectability of the birds; it is more humane to pity their ignorance. Would it be presumptuous of us to challenge them to quote an authority supporting the terrible denunciation that Pigeons are "low?" In genteel society this verdict immediately extinguishes a thing. Punch relates that a Belgravian mamma corrected her son with the crushing remonstrance, "It's worse than wicked, my dear, it's vulgar." I protest against the rude behaviour of the ignorant classes throwing dirt on the beautiful plumage of the inoffensive bird. The mischief done is perfectly harmless. It is mud; it will brush off when dry.

Are Pigeons "low" because poor people keep 
them ? Many poor people are Fanciers : I am pleased to accentuate the fact. The reason lies in a nutshell. It is because Pigeons are an amusement not too expensive for their shallow purse to maintain. A rich man gives $£ 260$ for an orchid or $£ 1500$ for an engraving to gratify his elegant taste. The Patissier Francais recently sold for $£ 600$, and is a wretchedly printed little cookery-book of the Elzevirs; it is not worth a bundle of straw, for it is neither of use nor ornament. While the Psalmorum Codex, a rare book, was ransomed at the princely figure of $£ 4950$. The poor man cannot compete in this aristocratic domain of lavish expenditure. Yet he has a desire to excel in something. Here is a hobby in which he can meet all comers on equal footing-he can cultivate rare and exquisite birds. Does this render the birds low? Or, rather, is it not an exalting and ennobling trait in the poor man's character that he has the wit to appreciate a beautiful natural object.

Do you accuse a man of "low" taste because he loves flowers? The Spitalfield weavers reared tulips as well as pigeons. Their hobby was the one refining feature in their hard, busy, colourless lives. A flower and a bird, two of 
the most beautiful objects in nature; and to love either is to be made better by so loving, and it is only obeying the command of the Great Teacher who said, "Consider the birds of the air and the flowers of the field."

Surely a bird ranks higher in the scale of creation than a flower! Some natures being more sensitive and sympathetic ask larger return than a flower can give; a bird meets the requirement. To crown the enjoyment of our leisure hours "we crave for an eye that can meet us, a pet that will welcome our approach, and show that our regular visit is a joy to both. 'If only the beautiful flower upon which we lavish so much time, thought, and money to produce, if it could only turn round at our coming, if it could acknowledge gratefully the refreshing shower we bestow upon it, if it could meet glance with glance to show us that it shared the joy of every meeting, if, we say, a flower could do all this, then it would answer in nearly all respects to a fancy pigeon." *

Some men-men of vitiated tastes and sordid hearts_-smile with dull superiority at teachings drawn from such unpractical, such uncommercial things as flowers and birds. Their chief view

* Fulton's Book of Pigeons. 
of Pigeons are things to be slaughtered at Hurlingham; and as for flowers, they are just pretty enough to decorate a groaning banquet-table or a stuffy ballroom; and thus they realise for us the truth of the curse that a land which practically becomes to men a land without birds and without flowers becomes also a land without prayers, without angels, without songs-a dull, dead waste of business, of selfishness, mammonworship, and lust.

Pigeons are the most honourable birds; the Fancy boasts an ancient and illustrious descent. They are the favourites of Holy Scripture. Izaac Walton, bubbling over with enthusiasm, traces the origin of his pet pastime to the joyous days of the world's grey dawn- "Seth, the son of Adam, taught it to his sons, and that by them it was derived to posterity." I know of no historic document extant proving our "Fancy" to be as venerable as this. We are fairly beaten on this count. There is but one thing in existence rivalling the patriarchal age of the art of angling. I refer to a certain picture by an old master comprising the portraits of Adam and Eve. The oldest son of Methuselah is the reputed artist. It was painted from life before the angel drove our primal parents out of Paradise and locked 
the door in their face. It was found amongst the ruins of the Tower of Babel by an enterprising excursionist, who travelled in one of Cook's personally-conducted parties. According to tradition, this picture hung in Mrs. Noah's boudoir when the patriarch took his spouse and family a forty days' cruise round the globe. The remainder of the history attached to this precious treasure is shrouded in obscurity. However, this much is quite sufficient to set a friend of mine itching to buy it. If with solemn countenance you could rehearse to him the pedigree, he would rise greedily to the bait. You hook your innocent by the nose and make him come down heavily to possess the ancient miracle of art. $\mathrm{He}$ has a mania for old masters. If curiosity hunters squandered $£ 17,500$ on three small and useless articles of furniture from the Hamilton Palace collection because they once were the property of Marie Antoinette, what would they not pay for a feather out of the angel Gabriel's wing, the apron of fig-leaves that Adam sewed together in Eden, the bullet that killed President Garfield, the hemp rope that Marwood, late Crown Officer, used whilst conducting his professional engagements! Fashionable taste is ridiculous. It worships the stupid and the sense- 
less. It converts ugliness into a virtue, sets a premium on inutility, and patronises the absurd. An Almond Tumbler clothed in its gorgeous apparel is worth a sackful of old china teapots and cracked dishes. The whole collection of gimcracks that crowd the cabinet of a fashionable drawing-room would not redeem the imperial creature from my loft.

Now concerning the pedigree. It starts at the Deluge. It was a pigeon that brought the good news to Noah of waters assuaged. On its return from a fly round, it alighted on Noah's hand, and he brought it into the ark. That bird, no doubt, was a family pet. (Dove and pigeon are synonymous: dove is Anglo-Saxon, pigeon is Norman.) The Psalmist frequently introduces the dove as an ornament into his sacred poetry. He sighs for the wings of a dove that he might fly away and be at rest. $\mathrm{He}$ also reminds his countrymen in picturesque imagery of their national ups and downs: "Though ye have lien among the pots, yet shall ye be as the wings of a dove covered with silver and her feathers with yellow gold." Royal Solomon, his son, is equally partial to the pigeon in his "Song," whilst the prophetic writers continue to give it prominence. Isaiah inquires, "Who are these 
that fly as a cloud and as the doves to their windows?"

There must have been tame Pigeons in early times, and some of these old Hebrew Bards were Pigeon-Fanciers. By the style of their language you can tell they were acquainted with pigeon instincts and habits. Sitting on their housetops at sundown they loved to watch the birds sporting in the air. In the East, about sunset, pigeons emerge from their hiding-places, where they have been sheltering and sleeping through the heat of the day. They dart upward and career through the air in large circles, their outspread wings catching the warm glow of the sun's slanting rays so that they resemble burnished gold; wheeling round, they are seen against the light, and appear as if turned into molten silver. Most of the Oriental birds are pure white, or very light coloured.

I need not refer to their place in the Sacrificial Law. In all probability, when the Mother of Jesus visited the Temple carrying the Divine Child in her arms, two young pigeons were sacrificed on the occasion. At the Saviour's baptism in Jordan, the heavens were opened and the Holy Spirit descended in a bodily shape like a dove upon Him; and throughout the long 
reach of Christian Art, from the earliest times to the present day, the dove retains its place as the symbol of the Holy Spirit. The evil spirit invariably is represented under the image of the serpent.

Being the symbol of the Holy Spirit, it was not unnatural that Art should also adopt the

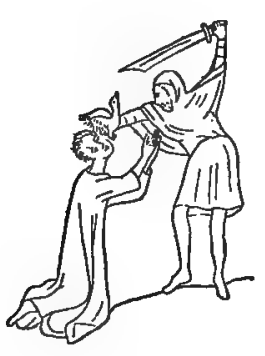
dove as an image of the invisible spirit of man - the soul. In the two following illustrations we have examples of it.

The above represents the death of a martyr who is kneeling before his executioner, and the liberated spirit is taking flight in the form of a dove. Below, the soul in the

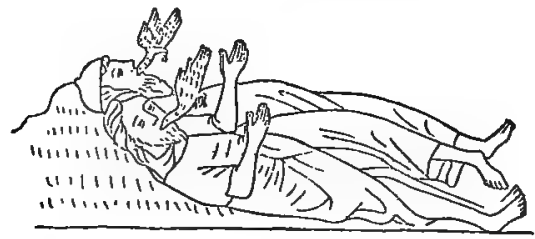

shape of a dove appears to be entering into, rather than departing from, the body.

Both these sketches are from MSS. of the fourteenth century in the British Museum. 
Over 2000 years ago the "honey-tongued Anacreon sung the praises of the Carrier Pigeon-giving it a poem all to itself. Anacreon was a rare specimen of human nature. Polycrates, the ruler of Samos, presented him with the large sum of five talents. He spent two wakeful nights thinking of his money, and then returned it to the giver, saying that it "was not worth the care it cost him." The Romans were ardent Pigeon-Fanciers. Pliny says of his countrymen: "Many are mad with the Jove of these birds; they build towers for them on the tops of their roofs, and will relate the high breeding and ancestry of each. Axius, a Roman knight, sold a single pair of pigeons for 400 denarii, or nearly $£ \mathrm{I} 3$ modern currency.

In India pigeons were alway highly esteemed. Akber Khan, about the year I600, was an inveterate and extravagant fancier-never less than 20,000 were taken with the court. The monarchs of Iran and Turan sent him some very rare birds; "and," continues the same courtly historian, " his majesty by crossing the breeds, which practice was never practised before, has improved them astonishingly." The native rulers in India still remain faithful to the old Fancy of their fathers. Mr. Lyell says: "I have seen the pigeonries of 
the King of Oude, who is probably owner of the greatest number of choice pigeons in the world, his stock numbering thousands." Affection for animals is innate in the Oriental nature; this probably is owing in a great measure to the religious ideas prevalent with them. Mahomet in the Koran tells his followers: "There is no kind of beast on earth, nor fowl that flieth with its wings, but the same is a person like unto you: then unto their Lord shall they return."

The Oriental, thus instructed to regard animals as his fellow-creatures, and as going on like himself to an immortal destiny, naturally treats them with respect and with some share of courtesy and benevolence which he manifests for the beings of his own species. The effect of such a system after many years is remarkable. Creatures which in our country fly from man with habitual terror readily enter into his society in the East. I have often in Syria, says Lamartine, seen birds caught in the morning by the children, and perfectly tame in the evening, having need neither of cage nor string to retain them with the family that had adopted them, but fluttering freely among the oranges and mulberry trees of the garden; coming when called, and perching of their own 
accord on the children's fingers or heads of the young girls.

We learn from "The History of Hainaut," by Jacques de Guyse, who lived in the fourteenth century, that on the coronation of King Arthur of England four kings walked before him, each holding a sword of gold; whilst before the Queen walked four more kings, each carrying a white Pigeon, "according to custom." A similar custom prevailed in France. During the coronation of the French kings in the cathedral of Rheims a number of white Pigeons were liberated within the sacred fane. This custom continued down to the coronation of Charles $\mathrm{X}$. White birds were esteemed a happy omen.

The semi-savage Hungarians of the tenth century dreaded Pigeons, as the following interesting story shows:-A band of these barbarous warriors, intent on plunder, approached the Abbey of Lobbes. The monks shut themselves up with the villagers in the Church of St. Mary, which they fortified, resolving to defend themselves valiantly. Vain efforts! The besieged were overwhelmed by numbers, and had already began to embrace, having no other hope before them than death or captivity, when. all at once by some special grace of the Divine goodness two 
pigeons came out of the church and flew three times round the Hungarian forces. A heavy shower which fell at the same instant relaxed their bowstrings, and prevented the barbarians from accomplishing theirferocious purpose. Panicstruck, they fled with such haste that the chiefs had to use their whips on those who still sought to continue the conflict.

Concerning the pedigree in England, Spitalfields is the cradle of the Fancy. Instigated by the royal tigress Catherine de Medici, at night, on the 24th of August 1572 , commenced the dark tragedy of St. Bartholomew in the streets of Paris. The leaders, the Dukes of Guise, Nevers, and Montpensier, riding fiercely from street to street like demons of the storm, roused the passions of the populace into frenzy by their cries, "Kill, kill! Blood-letting is good in August. By the King's command. Death to the Huguenot! Kill!" Sixty thousand trained hands did their bloody bidding. The populace, playing the afterpart of jackals on a battlefield, prowled on the track of slaughter, robbing and mutilating the corpses in vile derision. For seven long days Paris was a scene of pillage and murder. The roads became almost impassable from the multitudinous corpses of men, 
women, and children-a new and ghastly barricade. What was done in Paris was repeated in the provinces, till over 100,000 Protestants are supposed to have perished by the sword. The numbers butchered are computed, the numbers that sought safety in flight are uncounted. Thousands sought refuge in London alone. Those who had been engaged in the fabrications of silks resorted to Spitalfields. It is freely admitted that the refugee-artisans were amongst the bravest, the most loyal, and the most industrious in the kingdom they quitted, and contributed much by their knowledge and skill to improve the manufacture in England. In the middle of the last century we find the numerous community resident in Spitalfields had brought the silk manufacture of England to so great perfection as to equal the finest productions of any foreign nation, thereby showing the daily occupation of these people called forth efforts of no mean order in carrying out their handicraft. In 1773 an Act was passed giving them a book of prices for their work on a very liberal scale, which enabled them to live in a comfortable condition. They maintained the book of prices for fifty years, during which time they were very prosperous. 
The working out of beautiful designs in silk depended entirely upon the skill of the weaver. The nature of the employment required means of relaxation, as the brain as well as the hand was sorely taxed in preparing the looms for new patterns, together with the monotony of the occupation confining them in the house all day, produced a desire for some hobby as a set off. Whatever they undertook by way of recreation they carried out well. Their gardens were kept in the most exact order; the beds of tulips and ranunculus were simply perfection. Their stock of bulbs, being highly cultivated, and handed down from father to son, increasing in value each generation, were preserved with most scrupulous care. Pigeons also were their hobby. Their birds were a source of perennial delight. Being always at home they were enabled to pay much attention to them, and were very successful in the culture. Not being in needy circumstances, they were able to keep the rare specimens, thereby arriving at great perfection. As an instance of the interest taken in the Fancy, at that time there was scarcely a tavern in the district but had fixed round the public room pens for Pouters; these birds being always on show during the winter months. Whilst these people 
had good wages there was general prosperity; but, unfortunately for them, in the year 1824 they lost their book of prices, home and foreign competition soon reduced wages, and away went the tulips and the pigeons to the highest bidder, and the culture of high-class birds began to decline among the weavers, and gave opportunity to the gentlemen of the Fancy to obtain rare specimens from those who, but for altered circumstances, would not have parted.

Amongst the readiest to embrace the advantages thus offered of obtaining the choicest birds were the canny Scotch Fanciers. Mr. Huie, many years ago, when on his journeys in England, was always on the look-out for something good. In London he visited among the Spitalfield weavers, and "seldom," relates Mr. Ure, "returned home to Dundee without bringing or sending some rare specimens-mostly Pouters and Shortfaces." The Scotch pouter fancy of to-day is built almost entirely out of the scattered and ruined lofts of the Spitalfield weavers.

In England to-day Pigeon-fanciers are multitudinous, and their numbers, drawn from all classes of society, are constantly augmenting. These facts can be tested by considering the rapid increase in the number of Annual Shows 
that are held all over the country, and by consulting the show catalogues describing the vast assemblages of birds that are brought together, supplying in each instance the owner's name. The first public Show held in England was at the Baker Street Bazaar in 1852 , under the patronage of Prince Albert. At the head of the Fancy ranks Her Majesty Queen Victoria, whom I have been informed has a splendid collection of birds. $\mathrm{Mr}$. Fulton has had the honour of supplying Her Majesty, and the account of the first transaction no words better than Mr. Fulton's own can describe. The birds that exchanged hands on this occasion were a pair of red Jacobins :-

"I had an application from a Mr. Tait, the address and letter being in a most beautiful handwriting. The place I took to be Shaw Fame. I replied, stating the price. The answer came to send on the birds. I replied that my terms to strangers were post-office order or cheque, payable in eight days. The answer duly came, but this time with the heading of the paper representing the stamp of Royalty, and upon seeing the cheque enclosed, and reading the letter, I found I had refused sending birds on approval to our Most Gracious Majesty the Queen of England! "Oh! to Jacobin fanciers, I need not tell how 


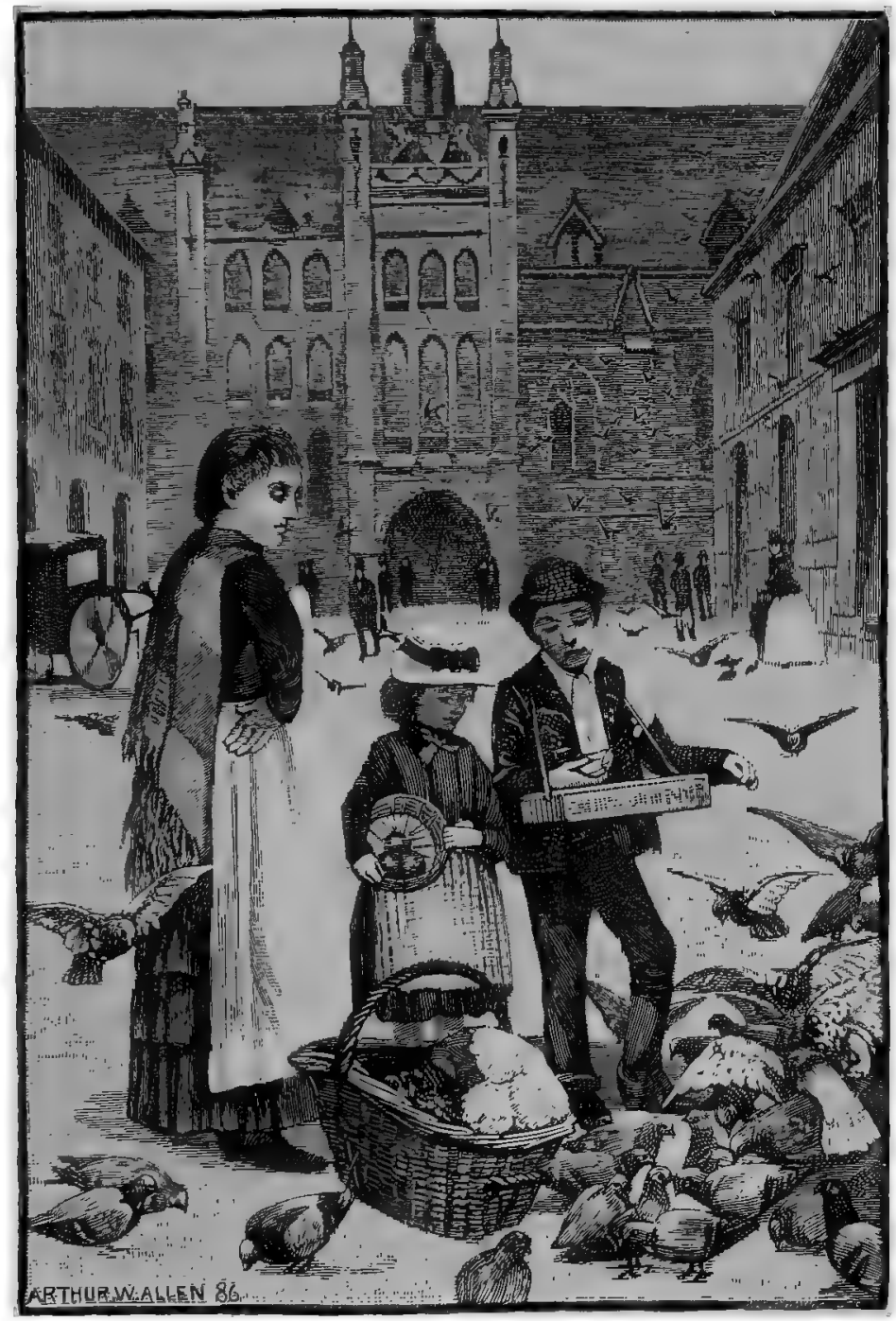

THE GUILDHALL, LONDON,

(From a Painting by Arthur W. Allen.) 

I felt I was a gone coon. I had to sit down and ask the missus for a wee drap of the cratur to sustain me. But the further perusal of the letter gave me to understand that I had given no offence in refusing to send the birds before receiving the money; also, that my terms were perfectly straightforward, and that I would doubtless be pleased at having the honour of supplying pigeons to the Queen of England. I need not add I felt myself a fool that day. Of course the address was the cause of the blunder I made, which address was intended to read Shaw Farm; and, moreover, there was no mention in the first letter who the pigeons were for."

It is gratifying to see that the citizens of London, following the example of the Venetians, are manifesting a growing fondness for Pigeons. Small flocks of motley-coloured birds congregate and breed undisturbed in the heart of the great metropolis. Hovering around our public buildings, nestling in the intricacies of the architecture, they form a beautiful adornment to our moneymaking city these comely pensioners on the public bounty. I have seen men of the careworn face and restless eye pause in the courtyard of Guildhall and watch them. Their anxious features relax into a smile; they become interested and 
amused at the docility and dignity of the birds, whose composure in the midst of a throng of pedestrians is exquisite. They are not scared at the rush of a reckless cab, or the loud yell of a telegraph boy. The courtyard is their rightful territory, and nothing less than the terror of immediate extinction from an uplifted foot, or revolving cart wheel, puts them on the wing.

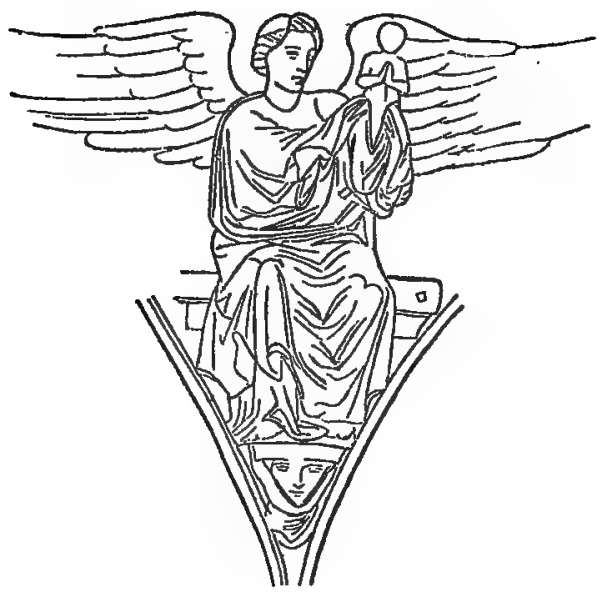




\section{CHAPTER IV.}

\section{THE CONFESSIONS OF A FANCIER.}

EARLY in life I developed a taste for "keeping" things. I kept foreign postage stamps. I kept rabbits, goats, and canaries. I kept a revolver, with which I shot cats and zinc chimney-pots. My father owning most of the zinc chimney-pots within circuit of our shooting excursions, on principle objected to our Cockney sportsmanship (a companion shot with me-an apprentice of my father's, an old ally and school chum of mine). $\mathrm{He}$ thought we might find rational amusement more suitable to young gentlemen than perforating zinc chimney-pots and frightening peaceable and well-paying tenants. $\mathrm{He}$ did not heed the perforated cats-they were not his property. We sold the revolver, and bought pigeons at Club Row.

$\mathrm{Oh}$ the feast of feather, form, and beauty displayed in that dilapidated old thoroughfare 
twenty years ago. A halo of romance pertinaciously clings to the first visit paid to Pigeondom in our happy halcyon days. I often look back with amusement upon the pleasant scene. A pale, eager youth-brimful of joy, tremulous with hope, enthusiastic in a new hobby, scanning the contents of shop windows, peeping surreptitiously through half open shop-doorswandering up and down like a lost dog in a fair - too timid to walk boldly in and roundly state my wants: Eventually all of a tremble I descended into old Crawley's den, and bought a pair of Baldheads, for which I gave 3s. $6 \mathrm{~d}$.

I started out that morning without any prior attachment influencing my choice. I wanted Pigeons. All breeds were equally pretty to me, because I was profoundly ignorant of them all. I threw the handkerchief at the bird I most admired on the spot. The Baldhead was my first love, and it has never since been deposed from the place of preference it then won in my heart. Club Row a quarter of a century since was in the full flower of its glory as the centre of the pigeon traffic. Modern street improvements have demolished half the thoroughfare, whilst the rise of multitudinous Pigeon-clubs has completed the work of ruin, for most of the 
buying and selling that used to be done in shops is now transacted privately in the club-rooms. Sic transit gloria mundi.

Exultantly I hurried home and deposited my pigeons in a shed previously prepared for their reception in the garden. I felt up in the air for several days afterward, and spent every spare moment I had in company with my Baldheads, watching their merry movements and manners. I soon came to the conclusion that a single pair looked cold and comfortless by themselves, and resolved to possess a pair of every colourblack, red, yellow, blue. After repeated visits to Club Row I brought my stud up to the standard of completion. There was now increased flutter and animation and merriment in the old shed. Oh the hours I lingered there, deliciously unconscious of everything but the present moment!

I soon learnt that there were birds and birds; and that mine fell woefully below the standard of perfection. Light dawned gradually, and thus the mystery of "points" was disclosed to me. Pearl eye, clean thigh, clean cut, ten a side were items to be reckoned with. Heretofore ignorance was bliss, now knowledge became exasperating. I weeded out the defective birds, 
replacing them with better specimens. It was hard to part with those early purchases. It felt like betraying old friends to sell them. There was no alternative. I was awake: the dream of their beauty had vanished from me. I saw a bull-eye was ugliness, and a dirty thigh an abomination to be got rid of. The first pair of eggs laid transported me into the wonderland of mystery and delight. I handled them cautiously every time I entered the shed. How I teased the setting birds by my inquisitive intrusion upon the privacy of their domestic duties. They charged me fiercely with beak and wing. I was too curious to be denied. Impatiently I waited for those eggs to transform themselves into pigeons -they did hatch with all my meddling. It seemed the only object I had to live for at the time. At last the young ones broke out of their house of bondage, and introduced themselves as large as life into the world of living creatures. I was enraptured-it was the first natural increase of my stock. The old shed soon became too strait.

My father had silently and complacently watched the new hobby-it succeeded admirably from his point of view: it kept me at home in the evening, and away from the contamination 
of evil companions. I asked him to build me a larger place. After undergoing a mild course of intermittent coaxing and teasing he consented. $A$ vast and aristocratic brick structure, to feet by 6 feet, quickly arose on the site of the ancient wooden shed, supplemented by ample outer aviaries formed of wire-netting. How the birds did enjoy their new quarters! They had more light, more liberty, more playground, and I enjoyed it as much as they did. I fixed the nests and perches, and did the whole of the carpentering myself, and entered into no other amusement until I could pronounce the job to be done in a good and workmanlike manner.

My father, with smiling countenance, frequently dropped in to inspect progress as a sort of clerk of the works, and offer gratuitous suggestions. But he was uninitiated-he knew not the four points of a Baldhead; what could he understand about the construction of a pigeonhouse? Occasionally he brought a pair of birds home for a present. I did not inquire the cost of them. He was kind. I loved him for it, and thankfully accepted his gifts. Yes, I have much to thank him for; he did much to keep me straight in life. Besides encouraging me in pigeon-keeping, he diplomatically executed 
another skilful manœuvre, by which he adroitly turned the wayward tendencies of his son. We were playing a round game at cards at an evening party. I enjoyed the game-cards were new to me. I never saw them at home-they savoured too much of the world, the flesh, and the devil. When the game was finished my father rose and said it was time to go home. "I'll stay a little longer," I replied, "and play another game." "You had better come now," he said; "if you want to play cards, play with me at home." We left together. I was perfectly good-humoured: the suggestion pleased me. My father bought a pack of cards and taught me to play, and many and many a merry winter's night we two spent with the cribbageboard between us, and my mother looking on. The passion for cards soon abated; I played in good company, and had plenty of fun, without the accursed adjuncts of drinking and gambling.

With my establishment in full swing another ambition burned in my breast-I must have a pair of shortfaced birds. So, together with my friend, I visited an old Fancier resident at Bow ; we each purchased of him a pair of almond-bred birds, Chapman strain. My poor plebeian Baldheads doubtless felt degraded by this intro- 
duction of blue-blood into their midst-from henceforth they became wet nurses to the patrician Almonds. They performed their humiliating duties faithfully and affectionately. My friend soon grew tired of his hobby, and disposed of his stock by tucking his Baldheads under piecrust and selling his Shortfaces to me. I often wonder what has become of that cherished youth and boon companion of mine, for he quickly afterwards dropped out of my ken. I love to think of the friends of my boyhood-they are my real friends still. I talk with them and walk with them as of yore, and the best of it is we do not quarrel with one another now as we used to do then. How we swore eternal friendships in those roseate, mirthful, thoughtless days of old ; and, when parting, promised to write each other with the unerring constancy of juvenile lovers. We proved horridly faithless to our vows, and neglected correspondence. Perhaps it is unwise to renew it in the present. 'For aught I know to the contrary, that cherished youth may be in debt now, and need the loan of a few pounds to emancipate him from the fetters of pecuniary thraldom. He may be in a chronic state of feud with his wife, would make a confidant of me, and entangle me in the meshes of a domestic 
broil. Or he may have become itinerant agent for the Royal Bubble Insurance Company, and would inveigle me into insuring my life in his office. Under such equivocal possibilities as these, I deem it best to let sleeping dogs lie. I leave the idols of the playground alone, and am content to revel on in the same hazy, happy manner, and enjoy their society as the idols of the imagination.

For some years after this the Fancy flourished joyously, till the denizens of the aviary numbered fifty. Eventually I began to waver in my attachment to the birds. I did not visit them as frequently as I had previously accustomed myself to do. In a word the spell was broken, and in a rash moment $I$ conceived the base idea of parting with my pets. In the impetuosity of youth I sold them for an "old song."

Do you ask the cause of this false and treacherous conduct of mine? Ah, me! there is a woman at the bottom of it, as the man said when his wife fell in the well. I was in love, and occupied with the ethereal delights of courtship; and whilst living in the purple light of love's young dream I was oblivious to every other thing of a mundane character. I centred my thoughts, spent 
my time, and lavished my caresses upon the object of my adoration. My excessive ardour was not uncalled for. There was a rival in the field competing with me for the fair and comely prize of a beautiful wife. His devotion was excessively romantic-it would constrain him to call at the young lady's house in the early morning prior to the visit of the sonorous milkman, and leave a bouquet for the adornment of her breakfast-table-a little delicately scented note being just visible in the midst of the fragrant assemblage of flowers, which, when withdrawn from its dainty retreat and opened, revealed in delicately turned verse the passion that inflamed the donor's breast.

He who wins can afford to be magnanimous. I won. I bore no after-malice toward my rival for these honourable and ingenuous attempts to supplant me in my lady-love's affection.

After two or three years of happy married life a longing, in a mild form, returned to own a pair of my feathered favourites. I erected a small wooden shed in the garden, and put several pairs of Baldheads in it-unfortunately they were soon out of it. One Sunday morning going to feed them $I$ found the door open, and on closer inspection discovered the place vacant, 
except a pair or two of stone-cold eggs here and there in deserted nest-pans. The broker surely had not entered the premises during my absence and evicted the tenants, they having failed to pay taxes when due. Emerson says of the monkey: "They combed his mane, they pared his nails, cut off his tail, set him on end, sent him to school, and made him pay taxes." Why should the tax-collector draw a line at apes? This was not the embarrassment with my pigeons-they had been stolen during the night. I did not despair. I wore a light heart during the Sabbath. Early on Monday morning I searched Club Row and purlieus, and recaptured the stolen treasures with the exception of one pair.

After this caution I brought them indoors, and wired off a portion of a large storehouse on the ground floor, in which I lodged the birds. This arrangement did not work satisfactorily all round. The birds liked it-I liked it, but the household, after brief acquaintanceship with the new inmates of the storeroom, protested indignantly against their society: The "horrid noise" of their cooing, which is sweetest music to the Fancier's ears, grated discordantly on theirs, and the pungent odour which in warm 


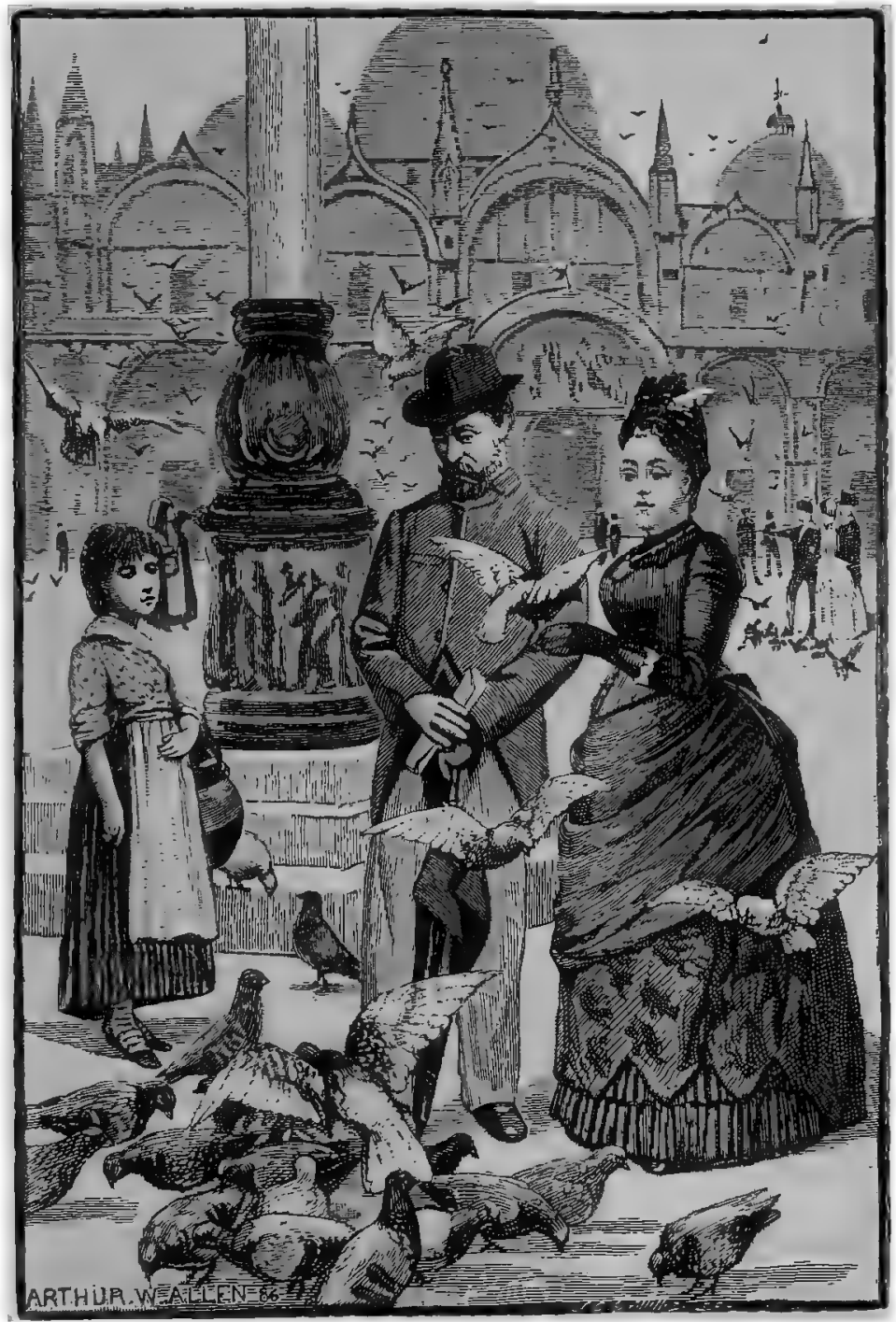

ST. MARK'S SQUAARE, VENICE.

(From a Drawing by Arthur W. Allen.) 

weather travelled through the perforated panels of the storeroom door, and wandered capriciously upstairs and downstairs and in my lady's chamber, brought matters to a hurried crisis. The birds were voted an unmitigated nuisance in the house. I pleaded their cause, but my eloquence was wasted sweetness on the desert air. I clung loyally and tenaciously to them whilst a shred of hope remained. I was ingloriously and overwhelmingly beaten. Their doom was sealed. I disposed of my stock a second time.

For several years after this I did not ride my hobby, although I often wished myself up in the stirrups. I frequently walked a considerable distance out of my way to pass a pigeon-shopan infirmity of which I am not yet thoroughly cured. Much time was spent during these years in foreign travel, which disturbed the continuity of home life, and rendered the keeping of birds an impossibility. It was not till one May morning four years ago, standing in the Square of St. Mark, Venice, surrounded by a contingent of the enormous colony of Pigeons established there, that the desire reasserted itself in a masterful manner. I resolved to recommence in the Fancy. During the remainder of our stay at Venice, when possible, I gladly renounced doing the picture- 
galleries and churches, and all the sublime attractions of gondoleering adown the grand canal paled before the choice delight of spending a quiet hour in the sunshine of St. Mark Square mobbed by a multitude of pigeons.

These birds, as all the world knows, are marvellously tame; but some of my readers may not know that they have been settled in the city ever since 877 . After the religious services on Palm Sunday, it was anciently the custom of the sacristans of St. Mark's to release doves fettered with fragments of paper, and thus partly disabled from flight, for the people to scramble for in the square. The birds caught were fattened and eaten at Easter, but those pigeons which escaped took refuge in the roof of the church, where they gradually assumed a sacredness of character and increased to enormous numbers. Formerly they were fed by the Republic, but now they flourish on a bequest left by a pious lady for their maintenance 'and on the largess of grain bestowed by strangers. Small bags of "feed" are sold on the Square. And as soon as the birds see a stranger with a bag in his hand, they instantly swoop down upon him and take forcible possession of the proffered repast. 
On returning home I erected a strong building of wood and iron. It is constructed of two thicknesses of wood sandwiched with double sheet-iron, the whole knit compactly together with stout flat bar-iron inside and out, tied with nuts and bolts. The place looks like a small fortress. With several locks, and the addition of an electric bell, I trust it is thief-proof. I know-

"The best laid schemes o' mice and men Gang aft a-gley."

Having done all I can to help myself, the matter is passed up into the hands of a kind protecting Providence, and I rest peacefully.

My place was soon alive with Baldheadslongfaced birds, of course-and very coarse indeed they were to one whose eye was familiar with the Almond Tumbler. However, they were good for a start; the full programme of my ambition being to raise a stud of choice shortfaced Balds and Beards. These birds have not had justice meted out to them by the Fancy. Like Tam o' Shanter's nag they have been left out in the cold, whilst Carriers, Turbits, Jacobins, and Almonds have been nursed, coddled, and beclubbed-artistically cultured, scientifically bred, and popularly patronised. My beautiful protégés are slighted-it 
is now quite time they participated in these higher privileges, and in their turn enjoyed the luxury of being fêted, fondled, and scientifically improvéd. But from what quarter to draw my first detachment of shortfaced Balds and Beards I knew not. $I$ advertised and answered advertisements, but to no profitable purpose-plenty of rubbish was shot into my lap from north, south, east, and west, to be returned with THANks!

I had heard of a celebrated Woodhouse strain, but the father of the feathered flock I failed to unearth, although I searched never so diligently, Mr. Woodhouse seemed as remote from me as the evening star, and inquiry brought him no nearer-whether he was in the body or out of the body I could not tell-whether he lived before the flood or after it I could not determine. I stood in doubt of him, and rashly concluded, like the flowery isle Atlantis, his existence was a fable.

At last the oracle spoke. An advertisement in one of the Fancy journals announced that W. Woodhouse desired to sell the remainder of his stock for $£ 45$. I replied in person, and brought home a half-dozen of the pick of the "remainders." From this casual visit paid to the venerable Fancier a cordial feeling sprang up between 
us. Other visits followed; more birds changed hands. The visits became a weekly institution, when much pigeon-lore was discussed in Mr. Woodhouse's loft, and many secrets of breeding and rearing were imparted to me.

I was in high feather now. Was I not within sight of the attainment of my dearly cherished project-a stud of goodly shortfaced Baldheads? My batch of new purchases looked quite stylish and handsome in my loft, their good qualities being heightened by contrast - they were in company of many of their lowly and inferior kindred. One creamy hen I received into my heart as an especial favourite; the delicate tint of her plumage and the gracefulness of her deportment quite captivated me. She was christened "Queen of the Aviary." Better birds than these I thought did not exist.

Ah! it is wonderful how much we have to learn in life, and how little we know even taken at our highest point of culture. The young man who has just passed his B.A. at Cambridge sells his text-books as waste-paper, and begins life with a finished education. A finished education, forsooth! Education is never finished. If the meagre stock of wisdom the young man possesses, compared with the vast quantity of 
the raw material that lies around him unappropriated-if his little stock would boil down to a solid, you might pack it into a small Gladstone bag and carry it comfortably with one hand. And the Railway Company that charges for luggage according to weight for a few shillings would frank it across a continent. Michael Angelo, the prince of painters, at the age of ninety, said, "Yes, I am still learning to paint." Education is never finished; so $\mathrm{I}$ find in the great Pigeon question. The Fancy keeps your intellect on the alert.

When I brought home that last supply of birds, I flattered myself my requirements were perfected-it put me in good humour. Happy mortal! I was charged with a buoyancy of spirits that nothing could discompose. This state of beatific calm suddenly collapsed. A difficult problem introduced itself upon my mind demanding solution - "Why are not shortfaced balds and beards as fine in head and beak qualities as the almond tumbler?" That they were inferior I dare not deny. That there was room for improvement in them I tardily confessed. The only reply I could frame, after a course of thought as familiar as the inside of his pocket to any one who thinks at all, was, "I suppose they have not been 
so assiduously cultivated as the Almond ; therefore they are inferior to it."

Alas! alas! my perfect birds were perfect to me no longer. My imagination had conceived a better standard. Having raised my ideal a step higher I must pursue it. Thus we make stepping-stones of our dead selves which lead on to fortune. After mature reflection I determined to improve my stock by fusing into it the Almond blood, and consoled myself by dreaming the delightful dream of founding a new and improved strain of Baldheads of my own. Mr. Gellett, an old Almond Fancier, being a near neighbour, I unfolded to him my requirement, and selected from his stud a dun, a red, and a kite hen suitable to my purpose. Here we pause. Seeing the case now is what lawyers call sub judice, we make no further comments upon it at present. Prudence bids us wait patiently until Old Judge Time pronounces his verdict upon it. 


\section{$(58)$}

\section{CHAPTER V.}

THE DUTIES OF A FANCIER.

ONE delightful benefit my Pigeons confer upon me-they have trained me to become an early riser in the summer months, for which I am grateful. To unbolt the door and step out into the garden at 6.30 is an achievement I am proud to place to my credit. The air is so fresh and pure and soft at that early hour, and so full of the perfume from the flowers, and redolent of the odours of the bleeding grass upon which nimble young feet have romped overnight. And the birds sing and twitter so cheerily in the trees, and dive swiftly and gracefully through the air in search of provender, that these engaging sights and sounds peculiar to early morning are quite exhilarating, and engage my mind with reverent and happy thoughts whilst busy in the aviary. 
"Our God, we thank Thee who hast made

The earth so bright,

So full of splendour and of joy,

Beauty and light ;

So many glorious things are here

Noble and right.

"We thank 'Thee, too, that Thou hast made

Joy to abound ;

So many gentle thoughts and deeds

Circling us round;

That in the darkest spot of earth

Some love is found.

"We thank Thee more that all our joy

Is touched with pain ;

That shadows fall on brightest hours,

That thorns remain;

So that earth's bliss may be our guide,

And not our chain.

"We thank Thee, Lord, that Thou hast kept

The best in store;

We have enough, yet not too much,

So long for more;

A yearning for a deeper peace

Not known before.

" We thank Thee, Lord, that here our souls,

Though amply blest,

Can never find, although they seek,

A perfect rest ;

Nor ever shall, until they lean

. On Jestus' breast."

Who would not rise early if they knew the luxury awaiting them at the banquet of the morning! Charles Lamb was an accomplished sluggard. Half-past ten he considered the very earliest hour at which a gentleman of leisure 
should abandon his pillow. The poet Thomson arose at noon. S. T. Coleridge vanquished both at this game of gentility, and occasionally could be found in bed at two o'clock in the afternoon. Oh that these drowsy dwellers in the Castle of Indolence had been Pigeon-Fanciers, then would they have mended their manners, for where "tumblers, croppers, carriers seize the gentle mind, they rule."

My first morning exercise is to replenish the fountain with clean water, and place in a familiar spot a saucer full of sopped bread with a little salt sprinkled over it. The birds enjoy this dainty dish. I give it only in the breeding season. Immediately I open the door of the loft a number of them fly to it and commence breakfast without saying grace. As they each fly out they pass under my eye, and the accustomed observer can speedily detect the sign of " going queer." After cleaning up inside $I$ do a tour of inspection round the nests; see that the brceding mothers and their rising offspring are all right; if an old bird is moping at home, instead of joining in the morning frolic outside, I say, "That bird is not well," and watch it accordingly. There are twenty nests in the loft, each one being two feet square. The fronts of them are half- 
covered with match-lining; the other half has a wire door to it, so I can enclose a pair to themselves if desirable. I find this arrangement convenient. If I unmatch and rematch during the breeding season, a brief term of imprisonment assists them to forget the old love and take on with the new. When I expect a hen to lay her first egg, I pen the pair till after the second egg is laid; this prevents eggs being laid astray. Returning to the flight (which is paved with bricks) I sweep it out, and am now ready to throw down the morning repast, consisting of a mixture of small grey peas, tares, millet, and canary. In the midst of these occupations, if the morning be fine, my little three-year-old daughter comes out to assist me. Dressed in gipsy hat and white pinafore she toddles up the garden and greets me with " Dood morning, papa; I have tome to help you feed the pretty birds." I cordially accept her proffered service, which generally consists of chasing a squeaker till she catches it, and then sitting down quietly somewhere out of the way to nurse it. If there is no squeaker about, I give her a "baby bird" out of a nest.

Permit me here to enter a protest against " hoppers." If birds have food always at command they are apt to eat too much, and too often and irre- 
gularly-grow fat, lazy, and dyspeptic. Worse still, having no regular meal-times of their own, they may neglect feeding their young. I do not like machine-feeding. It takes the poetry out of the thing. When the birds see me walking towards them up the garden they commence fluttering and flying about in a pleased expectant manner. Soon as I enter the flight the old silver hen flies on my shoulder, and gently pecks me as much as to say: "Make haste, please, it's dinner-time; I am hungry, so are the babies at home." I think the sight charmingly pretty to see a mixed multitude of Pigeons of various colourings grouping themselves at your feet engaged on the pleasures of the table. An amusing incident or two frequently occurs during the feed that is worth watching. There is a cock-bird mightily jealous of his spouse heavy with egg. He won't eat himself nor allow her to. The duties of married life demand her presence at home, so he hustles her about, following her up through the crowd-she snatching at her peril here and there a grain of food. By dodging in and out amongst the birds she slips him. On missing her he plunges wildly about, creating commotion, disturbing every one at table until the lost is found, when he greets her with a 
vigorous salutation of the beak and lovingly drives her home. On the fringe of the group is a squeaker just learning the art of foraging for himself ; shyly he pecks at a stray grain that rolls near him; scared at his own temerity he retreats hastily; emboldened by hunger he tries again and again at that grey pea till it is safely landed. Some fatherly old bird perhaps takes compassion on him as he squeaks at the wayside begging for food and fills his crop for him. Feeding by hand is one of the pleasures of the fancy never to be abandoned.

After spending an hour and a half with the birds my employment has sharpened my appetite, given a relish for breakfast, and I go indoors a hungry man.

About eleven o'clock I feed them again. By this time the setting hens are off the nests taking their morning exercise, and keenly ready for luncheon. I now put the bath in the flight. Pigeons are extremely fond of a splash in the pan. In their eagerness they sometimes crowd into it en masse. None will give way for others to bathe first; they all act the disagreeable, and remain a solid compact breathing mass heaped uncomfortably together in the bath until a quarrel breaks out all round, terminating in a 
general scatter, leaving two or three in possession to leisurely enjoy their bath.

Three or four o'clock is the hour of evening meal, which consists of peas, tares, wheat, and dari. In the winter the wheat and dari are replaced by rapeseed. About nine o'clock I look round all the nests and lock up. I peep in to see that all the squabs are fed for the night. If I find one with an empty crop I soak an osborne or milk biscuit to pulp in hot water, and, by aid of a glass syringe, inject as much of it into the crop as it will comfortably hold; and, if the youngster could speak and had manners enough, I trow he would thank me for his supper.

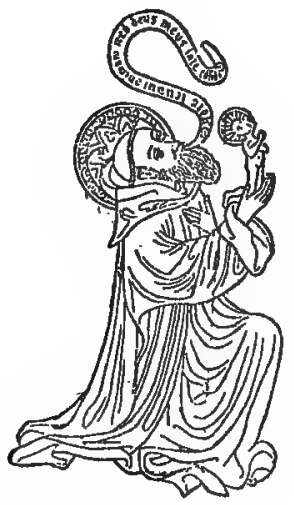




\section{$(65)$}

\section{CHAPTER VI.}

\section{A CAUTION TO FANCIERS.}

ThERE are several things I wish to mention on which experience has taught me a wrinkle. I own it a ticklish task to act the part of guide, counsellor, and friend-especially when you put what apparently is incredulous on paper-it makes your "credit stand on such slippery ground." When I visited the ruins of the Roman Forum my guide pointed out several fragments of broken marble beautifully carved, and said, "This is a portion of the Rostra from which Marc Antony pronounced his famous funeral oration over the body of 'sweet ' Cæsar." My enthusiasm quickened upon receiving this communication. I looked at the Rostra with added interest. I looked about hoping to find a relic that had belonged to Marc which I could carry home and show my friends. One is ever on the look-out for relics in Italy. You can buy plenty 
of them if fool enough to part with your money for what is not genuine. I searched around the Rostra for a real relic. Perhaps in the heat of his oratory Marc dropped his pocket-handkerchief-his spectacles rolled off his nose-he might have left his umbrella behind as he hurried off to plot with Octavius. If I could secure any of these articles my fortune was made at once. I found nothing, and in the pangs of my disappointment treated the historic spot as legendary lore. But had not our guide told us? Guides always tell the truth. Guides are not poets; they never create the yarns they spin, or imagine the history they rehearse. Guides are not novelists; they never manufacture romantic tales and indulge in fiction. Guides are not artists; they never draw pictures which are highly-coloured and glazed. Guides, gentle reader, are men of scienceexact science-grave, sober, prosy men, who never step out of the realm of clearly ascertained and established fact. Guides are men of honour -they never lie, therefore you can rely upon all the information they impart.

A great quantity of matter, mostly superfluous, has been written upon the Diseases of Pigeons, as though they are birds weakly and 
ailing by nature, requiring constantly to be under the influence of physic to stand upright on their legs. Experience teaches me to form a contrary opinion. Pigeons are of healthy and hardy constitution, and seeing they are not addicted to the suicidal habit of saturating themselves with alcohol, the bulk of their diseases are conferred upon them gratis by other people's neglect, carelessness, and ignorance.

To start with, the impression prevails that any place will do in which to house Pigeons. Any place will do if you wish them to live weakly lives and die untimely deaths. If anything is swiftly destructive to the health of our pets it is damp and draught-these things encourage catarrh, croup, and all bronchial complaints. Cold and heat they equably endure, but damp and draught are fatal visitors in the loft. Don't put them in a rickety old shed, through the cracks and crevices of which the winds whistle, and through the roof of which the rain percolates copiously. Make your loft wind and watertight.

At the same time give attention to

\section{VentiLATION.}

A besetting sin common to Fanciers is overcrowding the loft-keeping fifty birds where you 
have accommodation only for thirty. I have erred on this side, and suffered for my folly. On a summer morning, after a hot sultry night, I have opened my loft, stepped into it, and been nearly poisoned, inhaling the vile, reeking effluvia that filled the place. I retreated immediately before the pestilential odour, but the poor birds unfortunately were in it all night-breathing in it, sleeping in it, dying in it. I wondered why the nestlings suffered from ulcerous canker in the mouth and throat and pined away. I wondered why the old ones feeding, fell victims to the same malignant complaint. How could I cure them? I dosed them with sulphur and epsom salts-washed out their mouths with this solution and that, and they were nothing better, but rather grew worse. Life eluded my medical skill and quackery, and slipped deftly between my fingers.

After much thought, and blaming the food and blaming the water for sowing the seeds of death, it eventually entered into my head that perhaps the ventilation was defective, and I ended by blaming myself for not providing ventilation enough. The foul atmosphere soured the soft food stored in the old birds' crops, and when they gave it to their young it poisoned 
them, and the nestlings in turn poisoned their parents. I took out a sash and put up iron bars instead of a glass window. The atmosphere of the loft improved, canker disappeared, and has not since returned. So I attribute that visitation of epidemic to lack of ventilation. Perhaps other forms of disease may be traced to the same simple origin.

After ventilation comes

\section{Cleanliness.}

Do not let the droppings accumulate. Remove them wholly once a day. If you do not, vermin will multiply and attack the callow young in the nest, and suck them dry of blood. If you find a squab, two or three days old, looking puny and pale and death-coloured instead of ruddy-hued, the rascally bloodsuckers are at him hunting the precious life. Give a clean nestpan at once. If not kept under, insects storm the nests in such overwhelming numbers that the setting birds retreat before them, and reluctantly forsake their eggs or young. It is hard work to expel these predatory rascals when they are in possession. It is easy to prevent their visitation by strict adherence to cleanliness. When squeakers are a fortnight old I give a 
clean nest-pan, and when the nest-pan is done with, soak it in water and scrub it before putting it into use again.

Besides nest-insects there is the "pigeonlouse" - a little pest that dwells among the plumage of adult birds. These parasites are a terrible torment when allowed to increase and multiply unchecked. Many a valuable pigeon is done to death by them, and the owner does not know what ails the bird. A gentleman asked me, "Have you-any cure for going light?" I asked to see the bird. The poor creature, a beautiful almond cock, was handed me. Going light! with a cruel vengeance. But not the disorder commonly so-called. It was dying of utter prostration. Insects coursed over its body like rabbits in a warren, and swarmed it like bees in a hive. It was populous as a great city. It had fought for dear life till it could fight no further, so it gave up the unequal contest and sank exhausted. While I held the bird numbers of vermin crept off to my hand, hurrying and scurrying over it like pent-up schoolboys just turned loose for a frolic, or rather like rats hastening to desert a sinking ship.

The fault is, Fanciers do not closely inspect their stock frequently enough and observe their 
condition. At a distance the birds look clean and healthy-if one falls mopy, they catch it and pop a condition pill or other bolus down its throat, thinking that will set it right. If it mopes still, bolus follows bolus down the unoffending throat, producing civil war in the stomach. By this reckless method of ill-treatment they add insult to injury on the bird.

All insect powders I find impotent. Whatever you sprinkle on the plumage is soon shaken off. Ointment is the proper remedy-it clings. I wished to buy a bird. The owner honourably said, "I cannot sell it; it is out of sorts. Come again in a fortnight, and if it is better you shall have it." I went again. In the meantime the bird had been kindly put through a systematic treatment for a complaint it did not suffer from. It was no better (of course not); I could not have it yet. I inspected it closely and lifted up its feathers. It was literally alive with vermin. They might truly in deafening chorus have cried, "Our name is Legion, for we are many." I recommended ointment, and in a week when I returned the young lady was well and coquettish, and I completed my purchase. The ointment is compounded of $\frac{1}{4} \mathrm{lb}$. of blue unction and I oz. of lard. Place 
the two ingredients in a gallipot near the fire till melted-stir; let it set. It is now ready for use. By the aid of this ointment my birds are never troubled with insects. It keeps them scrupulously clean. Twice a year-in spring and autumn (oftener if necessary) - I inspect every bird on the premises. Lift up the feathers in parts of the body where insects lie snugly at home and apply the ointment, which is prevention as well as cure. I never admit a new purchase into the loft without its first undergoing examination, which is generally needful.

Apply the ointment sparingly. Holding the bird in the left hand, place a piece about the size of a large grey pea on the tip of the forefinger of the right hand; put it on the bird. The heat of the body melts it. Rub over the affected part as far as it will spread. A place where insects love to congregate is under the lower beak. Here they lay their eggs and dwell at ease, for the bird cannot molest them. The eggs are attached to the root of the feathers. They are small, round, whitish-sometimes half-a-dozen adhere to one feather. Gradually they multiply and spread up and up on either side of the head, round by the ears, and meet on the crown of the head. When the eggs succeed in complet- 
ing a ring round the neck the poor birds have a bad time of it. Rub the ointment well over, and in a day or two the nits will be shrivelled to nothing.

I think MEGRIMS is nothing more nor less than insects getting mastery of the birds in this provoking manner, attacking the head and inducing giddiness. I am supported in my theory by a correspondent of the "Stock Keeper," who wrote stating that he had discovered a cure for this otherwise incurable disease: "I took all the feathers off the top of the head, kept the bird in a pen, and within four weeks it was in perfect health again." Certainly it was, if my theory be correct. By plucking the feathers off the head, you remove the nits and insects which cause the complaint; and if the bird has not crossed the invisible boundary line between life and death, there is nothing left for it but to recover.

Another place where vermin lie in wait upon their victims is above the vent upwards, on either side the keel of the breast-bone-also on the under side of the wing. If the bird be badly overrun, apply a little ointment each day till the cure is effected. Don't use too much of it "at a time, or the remedy may be worse than the disease. It is an unfailing remedy. No Pigeon-Fancier 
can afford to be without it. It is the great cureall. Besides removing insects it cures rotten feathers, canker, wing disease, eye disease, and megrims. I cannot sing its praises too eulogistically. It has proved an invaluable ally to me in the hospital pen, and also to another Fancier, Mr. Woodhouse, who kindly divulged to me the secret of its healing virtue.

Now a few words about

\section{Diet.}

Feed small birds on small seed. Mr. Woodhouse attributes much of his success in rearing to adopting this method. Millet, rice, wheat, dari, small maple peas, tares, canary, and rape are all good, making tares the staple food, because to pigeons they are what bread is to man -plain healthy food, neither fattening nor stimulating, but nourishing. Beans and maize should not figure on the menu for short-faces. Always purchase the best quality. Whether Carlyle's dictum "cheap and nasty" is true in politics and clothes I leave the reader to judge, but in pigeon food I can vouch for its inspiration. Never buy your food ready mixed. Pigeon-mixtures are often made the medium for disposing of a quantity of inferior grain, which is almost impercep- 
tible unless the samples are closely inspected. I prefer to buy each of the different kinds of corn separately, and perform the mixing operation myself.

Pigeons require a constant supply of grit to assist in the digestion of their food; also a quantity of lime, to furnish materials for the formation of the egg-shells. A mixture of sand, old mortar, and crushed oyster-shells answers the twofold purpose admirably. A lump of common salt must never be absent from the flight for the bird to peck at pleasure. This is their one weakness-a love of salt. I will here give a recipe for a delectable confection much affected by the denizens of my aviary. The preparation of it is somewhat tedious, but the high esteem in which the birds hold it well repays for the outlay of trouble.

Mr. Woodhouse's Salt Cat :-

I peck of sifted loam and clay.

I $\frac{1}{2}$ lbs. of flour.

I handful of cummin.

I $"$ aniseed.

I " ground cloves.

I, carraway.

I $"$ fennel.

I, dill.

I $\quad$ fenugreek. 
I handful of powdered assafcetida.

$\begin{array}{lll}\text { I } & \Rightarrow & \text { common salt. } \\ \text { I } & \Rightarrow & \text { bay salt. } \\ \text { I } & \text { l } & \text { linseed. } \\ \text { I } & \text { canary. } \\ \text { I } & \text { hemp. } \\ \text { I } & \text { ground allspice. }\end{array}$

Mix all well together dry, then add water, and mix stiffly. Make into three lumps, and bake in slow oven for one hour.

This delicious aromatic compound is known by the euphonious name of "Salt Cat." Where the cat comes in I fail to discern. There is a tradition whispered through the Fancy that ancient Fanciers concocted a secret preparation for the delectation of their birds as gruesome and repugnant as witch-broth-one ingredient of which was a baked pussy-cat. Hence the origin of the odd name. For lack of one more appropriate, succeeding generations of Fanciers retain the title but omit the cat. There must, however, be something uncommonly scrumptious in dead cats, for if I mistake not, one had also to do with christening a certain strong drink "Old Tom." 


\section{CHAPTER VII. \\ THE FAVOURITES OF THE FANCY.}

I.

THE ALMOND TUMBLER.

The Almond Tumbler occupies the throne of supremacy in the Pigeon kingdom, and it bears its honours with becoming dignity and ease. The Pouter has his admirers, so has the Carrier, but the Almond is the "worthy chief" of the "wondrous three." Where is its peer? It is a prince of beauty, a paragon of comeliness, a banquet of splendour. Can you find another bird radiant in such magnificent clothing ; of carriage so courtly, and manners so engaging? The Pouter's plumage is a thing of daubs and patches. Its legs are models of deportment-encased in feathery breeches, terminating in an amplitude of Indian moccasin enveloping the entire foot in feathers. When standing on its block at full poise, the Pouter reminds me of Mr. Pickwick perched on his chair, dressed in elongated swal- 
low-tail coat, orating the savants of the club. The Carrier is flighty, wild, and fretful. He inspires awe and respect, at a distance. $\mathrm{He}$ is a grand bird, but he takes his grandeur sadly. The Almond is tame and sociable; stands trustfully on your hand; struts fearlessly at your feet ; submits condescendingly to a little petting. It is an amiable bird, and quite companionable.

As a sub-variety of the Tumbler class it is not of long descent. It did not come over with the Conqueror, nor establish itself in these islands during the ascendancy of the Saxons. It is a modern production; and a clear case of evolution by cultivation, having been produced from the common Tumbler. Many foreign favourites of insipid colouring and nameless grace have been introduced into our English lofts, but their novelty is their only merit. The Almond is indigenous to the soil, -it is an English bird. Mr. Jayne, an enthusiastic breeder of the Tumbler, when President of the National Peristeronic Society, delivered an address to the members. His subject was "The Almond Tumbler," and, among other wise things, he said: "You are aware my only hobby has been a short-faced Pigeon, and of all the varieties none can equal in my idea the Almond Tumbler; if for no other reason, I 
should admire it as a purely English manufactured Pigeon."

It was the first domestic Pigeon honoured by having a book written all about itself. Such literary attention was paid to it in the year 1802 by $\mathrm{Mr}$. Windus, a London solicitor. In I $85 \mathrm{I}$ the homage was repeated by Mr. Eaton. The first monograph has yet to be penned on the Carrier or Pouter.

It is interesting to trace what art has accomplished in 120 years, during which period the Almond has been diligently cultivated and brought to its present state of perfection. The first English writer, Francis Willoughby (1676), who refers to fancy pigeons, does not even mention the Almond. I suppose it was up in the clouds in his day. John Moore, in his "Columbarum" (I735), describes it cautiously as a novelty that he does not comprehend; so disposes of it curtly in few lines, most of which are occupied with discussing its name. At that date the name of the bird was unsettled. Some called it Almond, others Ermine Tumbler. Thirty years afterward it comes to the front as the favourite of the Fancy. It is described by the unknown author of the treatise of 1765 lengthily and lovingly. In fact, so enamoured of it was he, 
that he is of opinion that the title King of Pigeons, formerly conferred on the Carrier, should now be awarded to the new favourite, which deserved more than the old the honours of the purple. It was then "a very small pigeon with a short body, short legs, a full chest, a thin neck, a very short and spindle beak and a round button head, and the iris of the eye a bright pearl colour, and when in perfection is perhaps as great, if not the greatest, curiosity in the whole fancy of pigeons." From this gushing description we are prepared for something decidedly grand when the artist's pencil labours to produce the portrait; but from the accompanying illustration, reproduced from the treatise of 1765 , we see the pencil brings forth merely a pleasantfaced bird.

From this date the fame of the Almond was secured. It was impossible otherwise. Such a prepossessing bird was adapted to win its way into the affection of the Fanciers. They are a highly susceptible race of mortals; to them a thing of beauty is a joy for ever. After a lapse of thirty-seven years, bringing us to $1802, \mathrm{Mr}$. Windus writes his celebrated treatise on the Almond Tumbler. Mr. Windus was a solicitor, and in his trained hand the pen is a very 


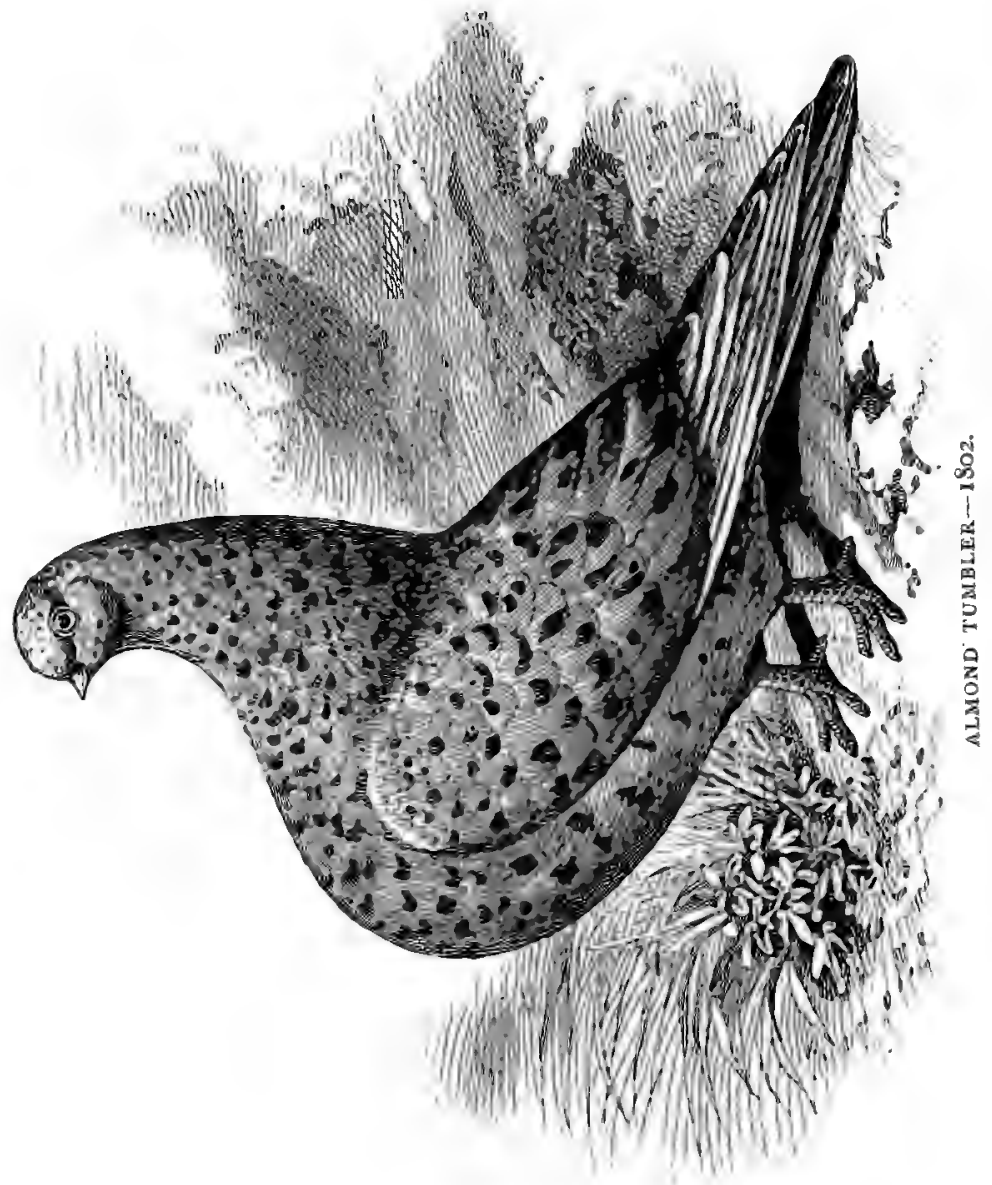






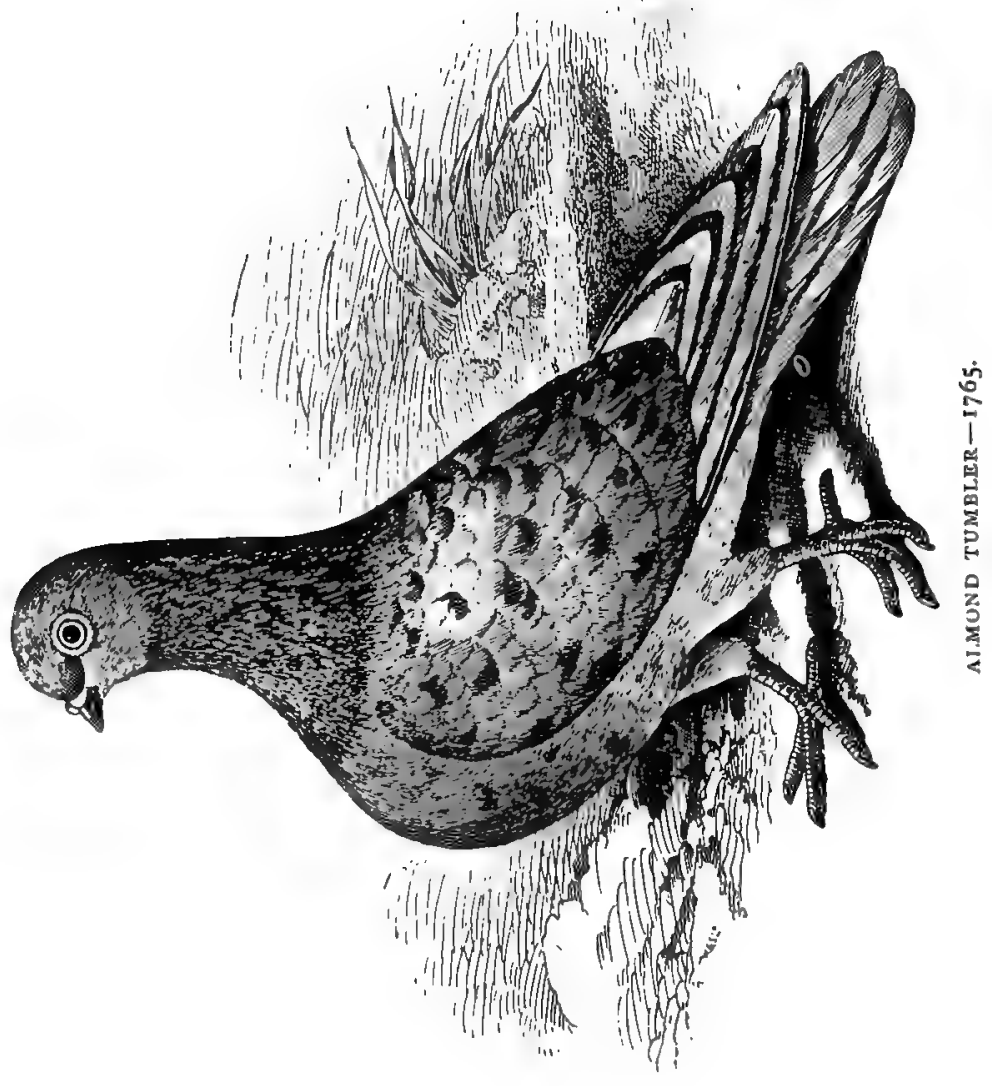


judicial instrument. It indulges in no flowers of rhetoric; it does not allow the branches of poesy to run over the wall. His description of the bird and its environments is severely methodical, unimpassioned, and business-like, but accurate in all detail. He was a good Fancier.

The principal record of advancement in the culture of the bird was that now feeders for its young have become necessary. The author of the Treatise of 1765 says of Almonds: "They require no attention while breeding provided you supply them with meat and water, and throw them a little straw." The Almond verily has refined its manner, requiring now a pair or two of wet nurses to wait on it. The accompanying illustration shows the bird of the period. At this date (1802) the standard length of beak was seven-eighths of an inch.

After nearly a half century of silence the voice of the enthusiastic Fancier, Mr Eaton, is heard discoursing quaintly and discursively on the merits and management of the Almond Tumbler. In I85 I he published his Treatise, which is a reprint of Windus, with additions by the author. This work puts us down on the threshold of the age we live in.

During the last eighty years, with the ex- 
penditure of much skill and patience, the bird has become wondrously improved in fineness of qualities. The formation of the head is bolder; the brow more beetling; the standard length of beak reduced from seven to five-eighths of an inch. The carriage is more spirited and graceful ; the contour more flowing and compact. If there be room left anywhere for improvement it is in the ground colour of the plumage, which wants redeeming from the present dusky red or mahogany brown to a rich toned yellow. The late Mr. George Chapman, of Cambridge, deserved thanks from all of us for his contribution toward the improvement of the bird in head and beak formation. Forty years ago he found the bird comparatively coarse in these qualities. When he passed away last July, he left it in its present perfected condition a legacy to us of a life's enthusiasm. Mr. Chapman has joined the mighty Pigeon Fanciers of the past, but he leaves behind him the memory of a great enthusiasm for the ideal, even as the fragrance of the violet lingers in the lane after the flower itself has been snatched away.

Every rose has a thorn. "There are tricks in all trades but mine," says the model business man; I must confess our hobby has a shady 
side to it. There are two kinds of Fanciers, the "head and beak" and the "feather Fanciers" - the former striving for grandeur in formation of head, the latter for splendour in colouring of feather. The head and beak Fancier is not above suspicion. He abhors a bird that is "mousy" or "pleasant-faced." It must have a grand "stop" to it, by fair means or by foul. So he drifts into the ignoble knack of "making up" the head of young birds, thus trying to reach his ideal by a short cut. Mr. Fulton, in his classic tome on Pigeons, reveals the method of the malpractice, for which candid utterance he deserves the warmest thanks of all honest men. There is no way of putting down an evil practice so thoroughly effective as dragging the monster out by the ear into the fierce light of publicity, and allowing a virtuous and indignant public to kill him by criticism. May the tireless clamour of public criticism assail the nefarious practice of crushing into shape a Tumbler's skull, until it becomes one of the sins of the past. It is a disgrace to humanity; it is the scandal of the Fancy.

The practice is cruel. Many young birds are killed, literally crushed to death, in the process. Those that survive suffer for life. In extreme 
cases, the nostrils being jammed together, the birds must breathe through the mouth, if they breathe at all, thus developing chronic bronchial disorders. The constant running and irritation which gives so much trouble is attributable to it. The torture is extreme. The bird is invalided for life.

The practice is immoral. It is fraudulent; it is done to deceive. The manipulated bird enters the show-pen as a natural specimen; it takes prize-money, and will perhaps be sold at a high figure. If that is not immoral conduct, I should like to know what you call cooking a balancesheet or forging a cheque! The system is a swindle, and only done to obtain money under false pretences. I heard a Fancier-dealer say : "They can do what they like, I shall make my birds ; I can sell them." Wherever it goes the made bird carries a lie on its face.

The practice is repulsive. The bird is rendered ugly, deformed by the vile tinkering and torturing it undergoes. I hold if you break the natural line in the contour of a bird you destroy its beauty. Nature is a better designer than you are. It is so in art. One false line or curve in a picture destroys the whole of the pleasing effect. You look at the picture and say: "Yes; a very 
fine figure, but the artist has made a mistake there. The drawing of that limb is false; it is out of proportion; it spoils the whole canvas." So it does, for you cannot keep your eye off the defect if you try to. Crush a bird's skull in, and the natural line of beauty is destroyed. The bird is rendered ugly, hopelessly ugly for life.

It is a significant fact, since this black art prevailed, "The number and character of Almond breeders," says Lewis Wright, " has declined, and more than one gentleman has left this Fancy in disgust as soon as he learned what he must do in order to win. The remedy is to give back the old prominence to "feather," and the result would be a return to that old state of things when the Almond Tumbler was the chosen pet of men of family and position." Set it down as a fact, grand heads can be bred honestly. I have seen them in the lofts of gentlemen who would not sell their characters for gold, nor behave barbarously to the pets they love so well. Honest men wish to breed quality, not to make it with a wooden tool. I have seen high class birds absolutely spoiled in this way. Their owner was incorrigibly addicted to the bad habit of tooling every nestling whether it needed it or not, that when he bred an extra good bird he could not 
keep his fingers off it. It now remains for the judges to support public opinion, and set the seal of their condemnation upon the malpractice, by disqualifying every flagrant example that appears before them in the show-pen.

It may not be uninteresting to give here a brief biographical account of Mr. Gellett, father of the Almond Tumbler Fancy. Mr. Gellett is, I believe, of Huguenot descent. Residing in the midst of the district where the busy weavers plied their shuttle and reared their birds, he is also associated with the honourable and ancient craft which once gave glory to Spitalfields. $\mathrm{Mr}$. Gellett is well into years, but is still ardent in his old hobby. Charles Lamb said of himself, "Our spirits showed grey before our years;" but of our juvenile veteran we may say age creeps upon the core while the dew is yet upon the leaf. Mr. Gellett wears the mantle which fell from his friend and master in the Fancy, George Chapman. Mr. Gellett says: "My recollection carries me back more than sixty years. A very curious pigeon came into the possession of a gentleman who wished to know its value. I was sent with the bird to an old Fancier for his judgment. He gave it the name of a dun Barb, but of little value. This afforded 
me the delightful opportunity of seeing his loft of birds, one of which instantly riveted my attention-a beautiful spangled pigeon. That is the only bird I retain the faintest recollection of in that loft-an Almond splash. Its gay feathers, its beautiful hackle and wings glistening with various tints, I can never forget, although I have seen and forgotten many things since that day. Three or four years afterwards I was in a shop kept by a man named Lemay, for the purpose of purchasing a pair of blue Dragons for a playmate, when a pair of charming little Almond Tumblers were shown to a gentleman, the sight of which fed my love of the birds, and kept it well nourished for many days. Many years elapsed before I again had the pleasure of seeing an Almond.

"I now became apprentice, leaving home, during which term several attempts were made to indulge my hobby; but having to trust to others, the game did not pay for the candle. However, if I could not keep Pigeons, I read about them. Every scrap of pigeon-lore was precious in those days. Reading the old book of 1802 on the Almond was a favourite pastime to me. I well-nigh knew the contents off by heart. 
"Married life, with its duties and responsibilities, together with the charge of an increasing family and slender means, put aside for many years the fulfilment of my cherished purposePigeon-culture; but the spark early kindled never died out. The long-deferred opportunity welcomely came. In 1860 business brought me into contact with an old Fancier of the Almond, and being by him shown some very fine specimens, I determined to commence breeding at once, and have continued so to do to the present time. Soon after this, being introduced by a member, I paid a visit one night to the Feather Club. Nothing but Tumblers were shown on this occasion-Almonds, Mottles, and shortfaced Beards. I was much surprised after the introduction to find myself in the company of gentlemen, having up to this period entertained the notion that whatever interest there might be in Pigeons, the company of those called Pigeon-Fanciers was not desirable. I was agreeably disappointed. After a few visits I became a member. At the time of my joining, the Feather Club consisted of but few members; however, they were a select few, with whom I am still proud to have been associated. I can look back over a gulf of time, quarter of a 
century wide, with unalloyed pleasure to those fortnightly meetings held through the winter months. Enlivened with the light-hearted jest and the merry laughter, the good-humoured discussion on the current doings of the Fancy, and a hearty welcome to 'Fanciers all'-joyous times, the record of which are cut deep into the tablets of my memory-very pleasant to look back upon, and to be thankful that such times were. The Feather Club eventually merged into the Gity Columbarium Society, which is a strong society at the present date.

"About twenty years ago my stud was enriched by the addition of several of my dear old friend Chapman's birds. Mr. Chapman had for many years been President of the Feather Club. After having discharged the duties of the office for eighteen years, he resigned through ill-health. To show our respect the chair was vacant the ensuing season, at the close of which I had the honour of being elected to succeed him, and was re-elected eight consecutive years. About this time a few of the new members became clamorous for competitive shows, which, with my predecessor, I always opposed, as being detrimental to the peace and harmony of the Society. I declined to be again nominated to the chair; 
and was gratified in receiving a very flattering testimonial, subscribed for by the old members, and whose names thereto attached will ever be dear to me, thus terminating my spell of presidency in a most agreeable manner. In I883 I purchased the whole of Mr. Chapman's remaining stock, consisting of a hundred birds. It is very doubtful whether any contemporary breeder of this interesting variety approached him either in quantity or quality. I therefore esteem myself fortunate in this acquisition, and am still desirous by all honest means to improve and raise the standard of excellence of this pleasing variety."

II.

THE BALDHEAD.

The Baldhead Tumbler. After the Almond we consider this the most beautiful variety of the Shortfaced family. Moore, the patriarch of the Fancy, does not mention this variety. Perhaps it was beneath his patriarchal notice. The author of the Treatise of 1765 seized the opportunity thus charitably presented, and puts original mat- 


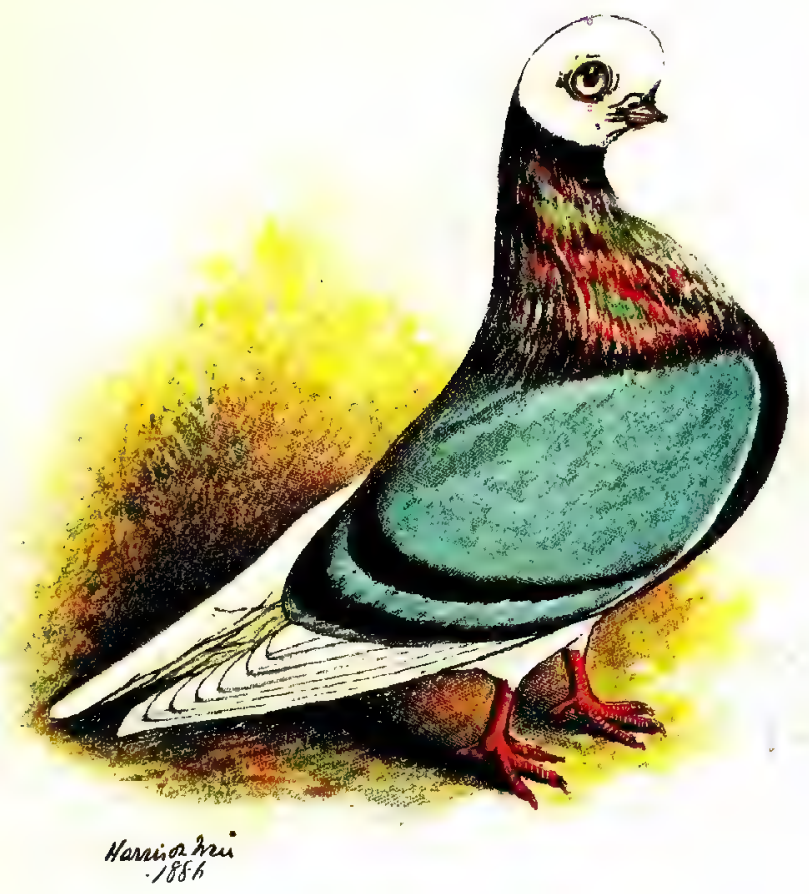

Blue Baldhead. 

ter into his book, of which there is great scarcity, by appropriating half a column to the Baldhead and his cousin the Beard. By the way, who is the author of that Treatise? The authorship of it has evoked within the circle of the Fancy as much anxiety and speculation as the renowned Letters of Junius produced amongst politicians and litterateurs sixty years ago. This being the first printed record of the Baldhead, it is worthy of reproduction in these less historic pages. The writer says: "The bald-pated Tumblers, which are of various colours in their body, as blacks, blues, \&c., with a clean white head, a pearl eye, white flight, and white tail, are esteemed good flyers, and are very pretty even when flying in the air, for the contrast of the feather appears at that distance when the weather is clear and fine."

So at present our favourite Pigeon is only a longfaced flying Tumbler worth eighteenpence. To our taste, no sight in the air is prettier than a cloud of Baldheads sporting on the wing, performing their evolutions and gyrations, provoking redundant amusement and admiration amongst the watchers on terra firma. These æriel acrobats are reputed to have sustained themselves on the wing from five to ten hours at a stretch. 
This remarkable accomplishment is the result of severe training and constant practice. Independent of these "champion flys," for which they are famous, Baldheads when at liberty are very pretty hovering about the house, if it be only a London house-one in a long sombre row of fifty, and the odd forty-nine houses being monotonous repetitions of your own. Even then they are a graceful acquisition to the dwelling, dawdling round the chimney-pots, loitering in the backyard, stealing mustard and cress seed from your irrate neighbour's garden-patch, or scratching among his sickly flowers in search of grit. Their plumage is shabby genteel, soiled and spoiled by the provoking nastiness of London filth and fog. But they are gay and blithesome withal. How much more graceful are they in the country where the atmosphere is of Arcadian purity, and the snowy whiteness of their plumage retains its immaculate delicacy all the year round. The vivid contrast of the white patches and the body colour is entirely picturesque, such as no other bird presents. They become tame and familiar, they will come in the door when open, perch on the window-sill, and be quite at home, and consider themselves members of the family as much as the dog or the parrot if you encourage their 
advances, and do not keep a cat, except it be a salt one.

The origin of the shortfaced Baldhead is uncertain. Whether it was bred down from the longfaced, or whether by a cross with the Almond, we cannot determine. I incline to the latter theory, because of the difficulty experienced in breeding shortfaced Baldheads with correct markings. Perfectly marked birds are common enough amongst their longfaced brethren; but with these there is a pertinacious tendency to run unevenly cut, dirty thighed, and speckled on the head or rump. These peculiarities seem to infer the admixture of alien blood; for it is a wellestablished fact that in all settled varieties the pigeon breeds remarkably true. I have in my possession a yellow Baldhead cock fine in head and beak, but its body feathers are broken similar to the Almond; also several white feathers in the tail are streaked with colour. I am informed the parents of it were perfect Baldheads, and sopnd in colour. In this instance they "threw back" a few generations, and thus revealed their ancestry.

I consider shortfaced Baldheads as difficult to breed as the Almond, and are quite as valuable. Good specimens are extremely rare, and the 
rarity is attributable to the difficulty of obtaining them good, not that the fondness for the variety has abated. Almost every Fancier at one time or other in his career has had a try for them. The birds breed generously, but throw'so many wastrels to one presentable offspring, that much as their friends admire them, they lack patience to propagate them. Instead of difficulty being an allurement to continue, they collapse under the first pressure of it, and turn their attention to an easier branch of the Fancy where they can win an easier victory.

Thirty years ago Matthew Eaton said: "The London Fanciers are now directing their attention to Baldheads and Beards owing to their scarcity. With their knowledge and judgment I think they will breed them up in a very few years as good as ever, although it is a work of time." We have waited patiently for the fulfilment of this prediction. "A very few years" is on the eve of expiration. The successful man is overdue, and when he comes what a splendid golden harvest he will reap! For these birds are greatly admired, and when of good quality, sell at long prices. A perfect shortfaced black Baldhead would readily change hands at $£ 50$. An engaging pastime this for 
one who is sufficiently enthusiastic and persevering to bring the shortfaced Balds and Beards up to the standard of the Almond. The work once commenced, every season will record its perceptible improvement. Nearer the Ideal the bird will approach in colour, form, and marking, until at last the one comes forth that is to astonish the Fancy-but who is going to breed it? Napoleon said, the word "impossibility" had no place in his vocabulary; the Pigeon-Fancier must expunge the same odious noun from his word-book.

The four points of the Baldhead are pearl eye, clean thigh, clean cut, and ten a side.

The important point, and the most difficult to obtain, is the

\section{Ciean Cut.}

That is, the line on the head which separates the white feathers from the coloured must be sharp and clean. If the white feathers dip down into the coloured, or the coloured feathers ascend into the white ones, the cut is irregular, and the charm of the bird's appearance is irredeemably undone.

The position of the line of demarcation on the head is a question of taste, some preferring a " high cut," others a "low cut." I prefer the 
low cut because it looks more finished and handsome, and is, from of old, the correct thing. Those readers who are familiar with Mr. Wolstenholme's beautiful drawing of the Baldhead, engraved in 1852, and published by Matthew Eaton, must admit the truth of this. A "high cut" bird looks unpleasant and unnatural. It is a burlesque on the beautiful. I know it is an unpardonable sin to contradict the throned opinions of your generation; nevertheless, I humbly assert the modern high cut bird is a monstrosity. Reducing the white on the crown of the head to a minimum, and driving the coloured feathers as high on the top of the head as you can get them, is undoubtedly the prevailing fashion. But in an age when fashion encourages such eccentricities as tight lacing, tight boots, chimney-pot hats, and high cut Baldheads, you are prepared for any aberration, however grotesque, it may be guilty of. If you want to keep fashion straight, watch it very sharp; if you do not, it will run off into the temple of folly, and worship at the shrine of ugliness. Some Fanciers change the term and call it close cut, but I dub it close cropped, for its appearance reminds me of some one recently liberated from Newgate. 
Push the perverted fashion to extremities, striving who shall get the highest cut bird in the show-pen, and what have you for your wasted pains? Half a Beard and half a Bald. In fact, a very high-cut Bald is a good Beard spoilt. It is now quite time that fashion was taken gently in hand and recovered to sanity and beauty. Then this cutting question would be at rest. This is the ideal cut.

The next thing desired in the Baldhead is

\section{Clean Thighs.}

In fact, all feathers on the hinder parts must be white - the thighs, the rump, the vent, and the

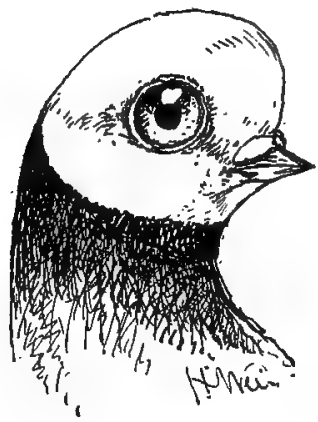
tail. As the bird stands with its wings folded not a coloured feather should be discernible in these parts. Sometimes one thigh is of similar colour to the body, sometimes both. This is called foul-thighed, which is a grievous fault.

\section{The Pearl Eye}

is another point to be carried. The iris round the pupils should be of a silvery white or pearl 
colour, and the brighter and more silvery this is the better. Frequently birds are "bull-eyed;" that is to say, one eye is of a dark dead colour. This fault prevails in birds that are low cut, and that have an excess of white blood in them. I have a beautiful black hen, otherwise good, but being low cut and fifteen a side is, of course, bull-eyed.

This fault is peculiar to Baldheads. I never saw it in Beards or Almonds, except in white birds Almond-bred, and in these it is called 'purry-eyed. I never breed from bull-eyed birds now, because I have proved by bitter experience it is spending time and trouble for nought. You rear a young one in the nest for four or five weeks, good all round. You are hopeful it will turn out well. Every morning with fearful joy you examine critically the eyes of the squeaker. One eye gradually gathers lustre and brightens beautifully; the other eye remains dull and dead as ditchwater, the old hereditary fault reasserting itself. Bull-eyed birds are a delusion and a snare. Do not breed from them if you would eradicate a prominent blemish which renders the Baldheads unsightly to look upon and provoking to breed. 


\section{Ten a Side}

is the next point to be attained-that is to say, the ten primary flight feathers in each wing should be white. The upper and lower mandible should be perfectly white also, not having a stain of colour upon them. Putting aside this, the head and beak qualities of the Baldhead are similar to the Almond, one standard answering for both birds. In fact, the Baldhead differs from the Almond in nothing but feather.

The size of the bird is an important consideration. It must be small-the smaller the better. Diminution in size is the result of inbreeding. Late-bred birds also are frequently small and weakly.

The colours of the Baldhead are blue, silver, red, yellow, black, with the off colours dun, creamy, mealy.

\section{BLues AND Silvers}

are the most numerous and the best quality birds. They should be matched together to improve the markings of both-Blue cock and Silver hen, or vice versâ. If two Blues are matched together, their offspring are apt to run down in colour, the blue becoming deeper and 
dusky. Two Silvers paired, the black bars on the wings of their issue will deteriorate-the blackness fading into a rusty brown, which give birds a shabby washed out appearance. Match the two colours together, and you correct the faults in each. The blue imparts density to the bars on the silver wing. The silver communicates the delicate soft tone to the bodycolour of the blue. Mr. Woodhouse's strain ranks the best amongst Blues and Silvers.

\section{REDS AND Yeliows}

are rarely met with possessing high-class shortfaced qualities. These do better when crossed similar to Blues and Silvers. The colour flies in Yellows when bred together for a few generations; in fact, they almost become colourless. Rich deep Yellows owe their heightened colouring to the Red jackets of their mates.

A name worthy of note, and inseparably associated with the Red Baldhead, is that of Mr. E. Burchatt of Croydon, an enthusiastic breeder of this charming variety. Mr. Burchatt bred his birds in and in for many years, and succeeded in producing a strain almost perfect as far as colour and markings were concerned. But his birds failed in carriage, eye, and head, till he in- 
troduced a magic drop of Almond blood into his loft. The bird selected for this experimental cross was a red Agate hen, excellent in head and carriage, and of Chapman's strain. This hen Mr. Burchatt matched to one of his best red Baldhead cocks, and the bird selected from this union was a hen of grand Tumbler properties, entirely red in feather except two or three white flights in one wing. This hen was paired to her father, and from the progeny of this pair a Red hen, fine in head and carriage, was selected to continue the experiment-the selected one having five white flight feathers in each wing, and a sprinkling of white feathers on the top of the head. This red-and-white hen was matched back to her father, and from this happy union suddenly sprang a very fine family of Baldheads-well-marked, of fine carriage, and broad and lofty skull, with typical eye and beak.

Some time after this success Mr. Burchatt was compelled, through ill-health, to dispose of his birds. They were brought under the hammer in Mr. Steven's sale-room. One or two were knocked down to Mr. Stuck, a rare old Fancier; but the cream of the collection passed into the lofts of Mr. Fulton. The prices ranged 
from $£ 3,5$ s. downward. Shortly before his death Mr. Burchatt said to his friend $\mathrm{Mr}$. Fulton: "Fulton, I feel I am leaving home to die. I have a desire that you get the best of my birds; but for you I should never had such good ones. I tried breeding two Balds together, but could get merely pleasant-faced birds-except those I made. The trouble with such I would never repeat. I read your advice how to get head and beak, and disbelieved it until Mr. Roper advised me to try it." Mr Burchatt never "made" another bird after this trial, for it never needed it.

His wife endeavoured to persuade the dying Fancier not to sell all his birds, but to take a few away with him when he left home in search of health. She feared the absence of the daily pleasure he derived from his pets would hasten his end. He replied: "I am content in having bred Baldheads to please Mr. Fulton. I fear if I did keep a few the time is so short that it would be useless; and perhaps they might die for the want of attention I now can't give them." Mr. Fulton bade his friend "Farewell!" and the two never met again. Mr. Fulton honoured his friend's parting desire, and purchased the best of his birds. 


\section{Blacks}

are rarer still, and very difficult to breed anywhere near the mark. They run coarse in head and beak; the feathers under the breast frequently shade off into a slaty tint. Do not breed from these defective birds. They may occasionally throw a good-coloured offspring, but the taint is in the blood, and will show itself most every nest. We want to breed it out. The rich, lustrous jet black, so admired in Carriers, is the beau-ideal black for me, if you please, and such is a treat to look upon, and a treasure to possess.

A high-bred Black Baldhead, caparisoned in its sheeny sable costume, surpasses the stately grandeur of a Spanish Hidalgo. And when, besides possessing the properties of a shortfaced Tumbler, the bird is well cut and clean thighed and ten a side, it is a prize worth having, and no bird of any other variety could be put in a pen with it alone without suffering by the comparison. To breed such a Baldhead is a supremely difficult task, worthy all the skill, ingenuity, judgment, and devotion an experienced Pigeon-Fancier can put into his work; and when it is an accomplished fact, the joy of 
possessing it and watching other people admire it will amply recompense all the outlay of time and patience it costs.

The most faithful and constant friend the Baldhead has had during the last forty years is Mr. Woodhouse. This gentleman is a keen Fancier, a clever breeder, a successful exhibitor, and he is profoundly intimate with the habits, requirements, and complaints of the Pigeon. We append a brief sketch of his career :-

\section{Mr. Woodhouse's Narrative.}

I began to keep pigeons when about nine years old, in the year 1834 . It was the agony of toothache that gave me a place amongst the noble army of Fanciers. My mother was gleaning in the harvest field one autumnal afternoon. I ran up to her crying piteously, making a frantic fuss of tears and screams. My dear mother, quite scared, asked, "What is the matter with you, Willie?" After more sobbing and stamping, and burying my face in her gown, Willie said, "I have got the toothache." My mother felt for her dear boy-dropped her armful of gleanings under the hedge of the harvest-field, sat me on the pile of brown corn, and asked to be shown the tooth that caused 


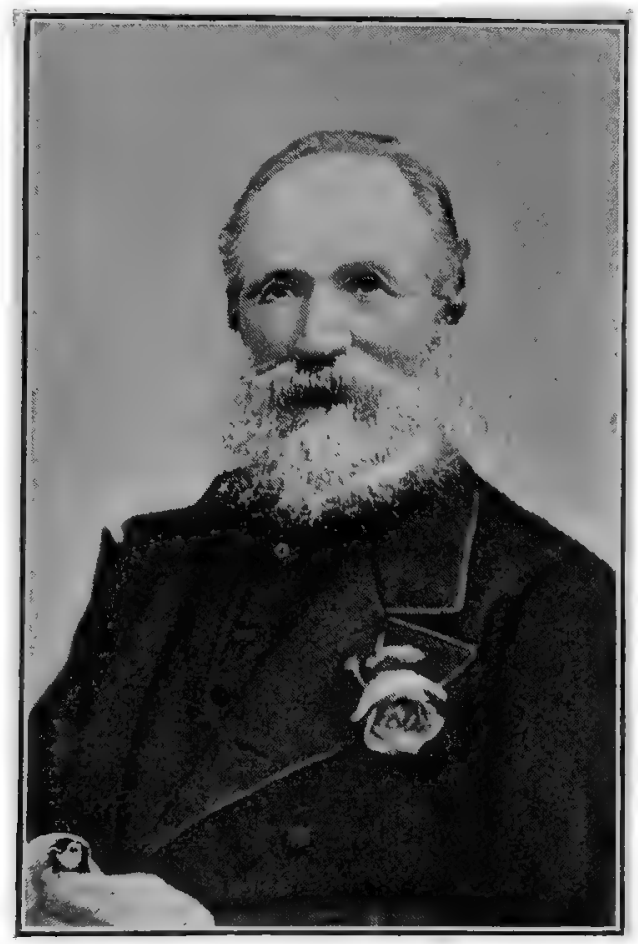

Mr. WoOdHouse. 

this terrible suffering and pain. "This is the one at the back."

"Yes; I see it. It is decayed, Willie. It must come out. You will get no rest until it is out."

Willie bellowed and capered about furiously at this awful consolation, and cried, "I can't have it out; I won't."

Mother said, "If you have it out, Willie, I will give you whatever you like best."

I closed at once with the offer and told her old Mrs. Rumbellow down in the village had a pair of young pigeons to sell, and I should like to have them very much indeed. So on that evening-oh, I remember it well, greyhaired man that I now am-mother took me to the village dentist. An old carpenter was this dentist. He understood more about jack, plane, and saw than he did tooth extracting. I was placed in the chair. I trembled all over at thought of the dreadful operation to follow ; my heart was in my mouth, but the pair of pigeons were in my eye, and these made me feel brave.

"Open your mouth; lean your head back, my boy," said the skilful practitioner. In went the instrument of torture, a wrench, a pull, and out came a tooth. But, alas! not the offending 
member; he had pulled out a sound tooth, its next door neighbour.

"Ben Fuller, what have you done?" exclaimed the fond mother; "you have pulled the wrong tooth out of my poor dear boy's jaw."

Ben Fuller got a jacketing for his clumsiness, and mother wound up her wrathful oration by saying to me in tenderest tones: "Willie, you had better have the other tooth out while you are here-remember the Pigeons. I did remember them, and consequently sat down again, meek as a martyr, and for the Pigeons' sake out came the right tooth at last. Hurrah! I had won the first pair of my pets, which still remain my pets to this day in the year of our Lord I886, just fifty-two years afterwards.

I have kept Shortfaced Tumblers about fifty years, so I am familiar with the birds and the birds are familiar with me. My pets are Balds and Beards. It is said by some Fanciers of the present day that they have never seen any of those equal in head and beak to the Almond Tumbler. A great many Balds and Beards have been bred by myself equal to the Almond. With them I have won the silver cup at Boston and Crystal Palace for the best Tumbler of any variety, beating Almonds, Kites, and Agates. 
This is how I first came to breed Shortfaced birds. When I was an apprentice boy, I said one day in the workshop: "I will tell you my favourite Pigeons - to my mind there are none like a pair of Yellow Baldheads." Thus I made my choice; but how to get them was the difficulty. I knew they were not to be had for money, because they did not exist. I knew I should have to breed them if I ever obtained them. I tried the experiment-the harder the task the more fascinating it gradually became to me.

I bought several birds at Club Row and Kent Street, Borough. Some of them had tidy knobs, and were so badly cut that I crossed them with pleasant-faced flying Balds, and recrossed till the strain began to improve in style by this method. Now and then I bred a better cut bird, with better head properties, and this encouraged me to persevere. In a few years I had quite a respectable-looking little family around me. I then began to exhibit them at Friendly Shows for the "benefit" of a Fancier in misfortune. Eventually my birds were much talked of, and would draw a good company when I put a dozen into a pen at one of these Shows. I began to be quite famous in the Fancy, for "Oh such charm- 
ing little shortfaced Baldheads!" and I felt proud of my success.

My earliest purchaser was Thomas Ridpath of Manchester. He was a real enthusiast. Hearing up in the far north of my shortfaced Balds, he took a journey of 200 miles to have a look at them. I shall never forget showing them to him-there were about fifty birds in all. "What is the price?" was his terse note of admiration. My answer was: "There-go in amongst them and take what you like at a guinea each." I left him alone to pick for half an hour, and when I returned he had chosen ten birds. I told him he could leave them with me till morning, as there was no train to Manchester that day. But he would not allow them out of his possession, and I learned from him, the next visit he paid to my loft, that he put them under his bed that night at the hotel. He did not dare permit them out of his presence. He showed them at Manchester and elsewhere, and won First for them, and continued to do so, as I would not show against him.

After a time another good Fancier came to my loft who did not mind $£$ Io or $£ 20$ for a firstclass shortfaced Bald. This new and true Fancier's name was Joshua Fielding of Rochdale, 
who won more prizes for shortfaced Balds and Beards than any other man, bar myself.

About the year 1855, one evening I called upon William Barber, who kept a Pigeon Shop in Slater Street, to have a chat, and to pick up anything good in my way. Who should enter Mr. Barber's shop but another old shortfaced Fancier, and never a better, as I afterwards proved. Mr. Barber mentioned my name in conversation, when the gentleman exclaimed, "Woodhouse! Is this the Woodhouse that has shortfaced Baldheads?" "Yes, this is the identical man," said Mr. Barber. "Allow me, Mr. Woodhouse, to introduce you to Mr. Bellamy the Almond Fancier." In course of a few days Mr. Bellamy was at my place in Old Street Road to inspect my birds. I took him upstairs; opened the door; as soon as he looked round the room, with uplifted hands he exclaimed, "Really! Woodhouse, I was not aware there was such a splendid stud of shortfaced Balds and Beards in existence. He asked what I had bred them from. I told him the truth: "From all sorts of odds and ends that I could pick up." He advised me to show them. I took his advice. I showed and won First at the Crystal Palace for Red and Yellow Beards, also for Bald- 
heads. This was about I856. After this I showed regularly. I bred a blue Baldhead cock in 1872 which proved the Champion of the Fancy. He started with taking First and gold medal at Rochdale. First also at Boston, where I met Robert Fulton. Mr. Fulton said : "I should like to buy the blue Baldhead cock-fix a price on him; only let it be reasonable." We walked together toward the bird, stood in front of his pen, and I replied, "Well, Robert, I have set my mind on that bird making me $£ 50$ before he leaves my possession. If you will give me that amount, the bird is yours." The bird remained in my possession. I showed it for several years running. He valiantly stood his ground, defeating all comers, winning many challenge cups, and taking the sweepstakes at the Peresteronic Show held at the Freemasons' Hotel. 'The bird made me the required $£ 50$. He brought $£ 38$ in prizes, and then at ten years of age was sold to Mr. Martin of York for £I2. Mr. Martin bred from him, and his stock has won ever since, and unless some one breeds better, is likely to continue so doing.

About thirty years ago I bred a very curious bird which created a lively interest in the Fancy and out of it. The parents of it were common 
Baldheads. But the peculiarity of this offspring was that from the crown of its head rose a crest of white feathers similar to that which embellishes the head of the great crowned Pigeon of the Indian Archipelago.

The following description of it appeared in the pages of the Poultry Chronicle of contemporary date :-" This curious pigeon is alive, and in my posséssion. It is a pure-bred baldpate, of which it has the properties - viz., clean cut, pearl eyed, clean thighed, and ten a

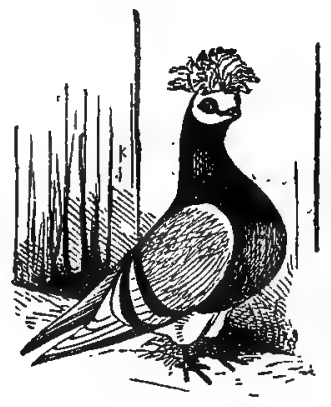
side. It is the only one in the world, and is a cock bird. Several competent judges have seen it, and consider it a freak of nature; but, whatever it is, it is a wonder. Several of my friends wish me to breed from it to get more, but of this I am doubtful." I sold the bird for three guineas to Lady Manners of Melton Mowbray. 
III.

THE BEAR D.

In shortfaced properties the Beard ranks behind the Baldhead as far as the Baldhead is behind the Almond. Beards have been sadly neglected in the last generation. Most Baldhead Fanciers have taken them on as a sort of supplementary fancy, but not treated them quite seriously. They generally occupy a secondary place in the loft. I kept Baldheads for many years before I owned my first pair of Beards. I am now very fond of them, for they improve on acquaintanceship. Several gentlemen, including Messrs. Masters, Towndrow, Lock, and Woodhouse, are now trying to rub out the reproach, and are striving diligently to improve this neglected variety, possessing the serene hope that they will soon land it in the front of the Fancy. May they succeed. The coloured engraving is of a bird in the author's possession. It is a portrait, not a prophecy.

The Beard in shortfaced properties is to be judged by the standard of the Almond, from which it differs only in markings. The points peculiar to this variety are very few and simple. The marking or "beard" which gives the bird 


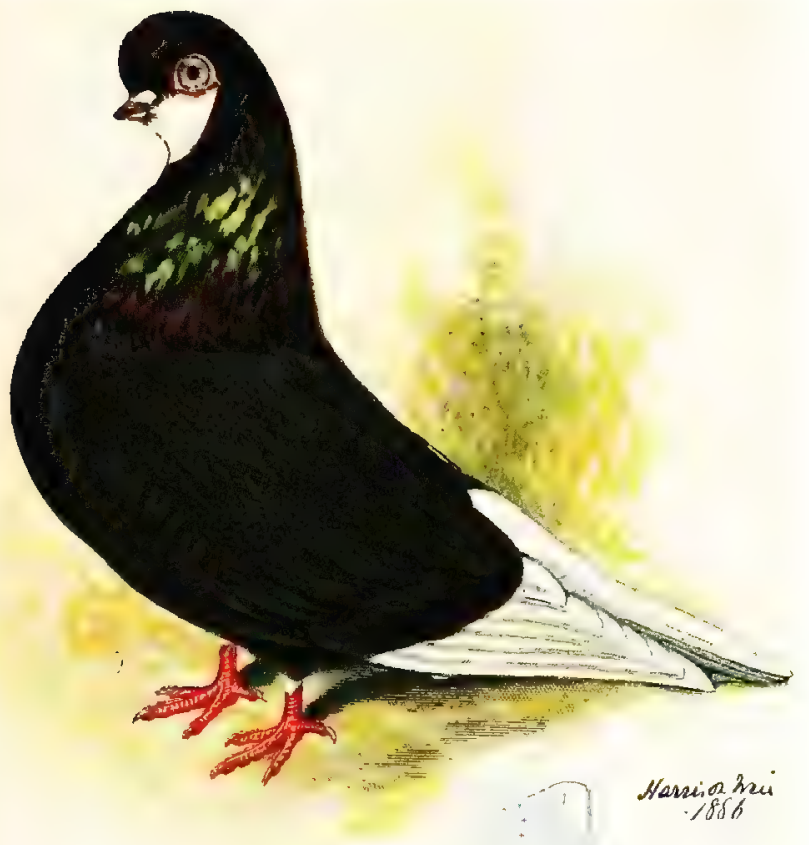

A Portrait from Life in Possession of the Author. 

its name is the principal feature, and consists of an unbroken crescent-shaped patch of white at the throat, below the beak. The foible of some Fanciers is to reduce the size of this white patch to almost microscopic proportions-just a speck of white under the chin. Judged by the standard of the beautiful, this class of Beard looks paltry and ridiculous. It tolerates a few white feathers on the throat certainly, but it looks as though they were there by mistake. We feel that their presence is an intrusion to be apologised for. Seeing it is the marking that gives the bird its name, let it be a bold feature, prominently observable, something to be admired. It is the contrast of colours that gives the bird its charming effect. Little contrast, little charm. Let it be pronounced as possible.

The marking most highly esteemed is what is termed the "swallow throat." The white feathers start from the eye on each side, and take a graceful curve downward to the throat. This makes the most attractive and showy-looking bird. The perfect "swallow throat" is difficult to obtain. Frequently a streak of white feathers wanders capriciously off behind the eye, on either side the head, resembling detached fragments of cloud straying away from the 
main group. Then, again, stray coloured feathers make incursions over the frontier line of the "white beard," and settle themselves promiscuously, irrespective of the beauty of the arrangement. Occasionally the dark feathers overrun the frontier in such compact masses that they reduce the "beard" to extremities, fairly exterminating it, except a dash of white

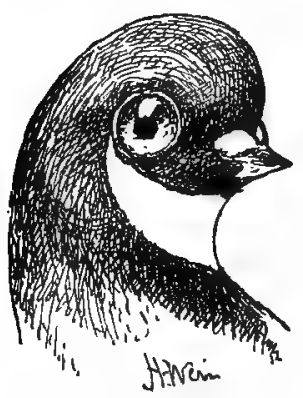
on each cheek, leaving the bird just sufficient to form a small and genteel pair of Dundreary whiskers. These last are termed "dark-faced." Dark-faced birds do not possess an agreeable appearance, and are valueless in the Showpen. They are useful for stock purposes, however, and, matched to fullbearded mates, may throw model offspring.

The above represents an ideal beard. The upper mandible in Reds, and Blacks, and Blues should be dark; the lower one pure flesh colour. The flight-feathers, as in the Baldhead, should be white, but are seldom found ten a side; yet the orthodox number, to the turn of the flight, should be perseveringly aimed at. Eight and 
eight are passable. The thighs must be of the body colour; tail and rump white; the legs also white feathered, or white "stockings ;" the eye pearl. Small birds are accounted the best. The best carriage birds are bred late in the season. Match a small cock to a large motherly hen. The cock gives size and carriage, and the hen stamina to the offspring.

The colours in Beards are similar to Baldheads, and should be matched in like manner to produce the best results.

One point in Beards and Baldheads has been much overlooked lately-viz., the shape of the neck. A thick neck gives a clumsy and common appearance to the bird; a thin, tapering neck looks graceful and effective.

Another fault common to all Red and Yellow Balds and Beards is, that the secondary flight feathers, instead of being solid red or yellow, as the case may be, shade off to white at the ends. I never remember seeing a bird without this fault, except a red Roller hen which was perfect in beard markings, but, of course, with the objectionable addition of feathered legs; the bird also was barren, or I should have matched her to a Red cock and tried to breed the fault out of my loft. 
Beard and Baldheads are subjected to the same cruel treatment that the Almond undergoesviz., "skull crushing." I hope a happier and more prosperous time is dawning for these beautiful birds of the Tumbler class, and that soon ugly specimens with upturned beaks, open mouths, and goggle eyes will disappear from the Show-pens, and be discarded for ever. The pure and delightful pleasures of a Pigeon-Fancier are sufficiently exhilarating in themselves to satisfy the ambition of the most ardent and aspiring natures.

\section{CONCLUSION.}

Parents, encourage your boys in their desire to keep Pigeons. The boy who will not play at cricket or football-who will not keep Pigeons or Rabbits because they give such a lot of trouble-such a boy is not the brightest speciman of the juvenile race. The worst lads are those who love nothing but loafing about-idle in school, idle in the playground, caring for no hobby. The Rev. A. Headly, popularly known as "Wiltshire Rector," informs us, "I have been a Pigeon Fancier all my life, from my early boyhood being allowed and encouraged 
in the fancy of my own respected father, who at eighty odd still enjoyed the sight of a good bird-fowl or Pigeon. ... I I am a father whose elder boys were allowed and encouraged by me to keep all kinds of pets, and my sons 'went straight' in life and have done well, and I think permitting them to have fancy Pigeons had something to do with it."

By encouraging your boys in their hobby, not only are you now providing them with innocent and healthful recreation, you are also laying up a rich legacy, which in after life when they withdraw from the cares and contentions of business may prove a precious and acceptable boon. Life has two seasons of youth-one at each end of it. Intuitively in our receding years we go back with a strange fondness and freshness to the tastes we formed in early life.

It is the orthodox English custom for the successful man to retire into the country to enjoy himself when his fortune is made. But what creature under the sun is so utterly miserable as the retired business man with nothing to do! To sit still is intolerable. He must be active. The problem is how shall he change his activity; he cannot stop it. He has acquired no taste for literature or art, and cares 
less for gardening-stooping makes his back ache. He will not grow cucumbers-they disagree with him. He has nothing to do. He has abundant energy, but no channel by which to run it off. He grows irritable and moody in his aimless leisure. He rises late in the morning-reads the newspaper at the breakfast table-goes out for a stroll, and talks politics with any idle neighbour he can lure into a discussion on topics they know nothing about. He takes a nap in the afternoon-dines sumptuously every evening at seven, washing down one course after another with wines of the choicest brand, and then steps into his carriage and is driven to a place of entertainment to kill the residue of the evening in mild dissipation and artificial excitement. Occasionally, to subdue an attack of indigestion, he takes a trip on the Continent, but returns home disgusted with the sightseeing and the parlez vous-ing.

'I know retired men of this type. A hobby was not one of the fine arts they cultivated in early life. The secret ambition of Mr. Pendennis was always to be a gentleman-their ambition is similar. But they were not to the manner born, neither can they now accommodate themselves to it. Like a badly made jelly they 
are pulpy; they will pour in any mould, but they won't set. One man I knew, his disposition turned sour in retirement; he made it uncomfortable for his wife and family at home-his only diversion was to quarrel with them. Another superannuated tradesman was enticed into a coal-mine speculation. His money went down the coal-shaft - and stopped there. Another man, after twelvemonths' experience of playing the gentleman, abandoned the irksome profession, took off his coat and plunged into business again. It was his salvation.

Oh that these men had been Pigeon-Fanciers in the days of their youth! They would have returned to the witchery of the old hobby and been serenely happy in it.

Farewell, Fanciers all, old and young! Quietly and peacefully enjoy your pastime. May gentle thoughts and generous deeds be its offspring. Of all living creatures birds get nearest heaven. May your thoughts, your hopes, and at last yourself, soar higher than they, until as an emancipated spirit you dwell for aye in the great overhanging home of mankind-the Paradise of God ! 


\section{N D E X.}

Almond Tumbler, 3, 77 .

Art of the Fancy, I4,

Baldhead, 90 ,

Beard, II2,

I_ow cut, 95 .

, Origin of, 93 .

Breeding, secret of successful, I8.

Burchatt, Mr, , roo.

Chapman, Mr., 18, 82, 89.

Cleanliness, 69 .

Clouds, ministry of, 4 .

Club Row, 42.

Cradle of the Fancy, 34.

Diet, 74 .

Early rising, $5^{8}$.

Eaton, Mr., 8I.

Education, 55.

Enjoyment, 6.

Enthusiasm, 22.

Fancier, a blind, ro.

Fancy, cradle of the, 34 .

," pleasure of, 6.

" refining influence of, 24 .

Fashionable frivolities, 27.

Fielding, Mr., 108.

Flowers, ministry of, 5 .

Friends of our youth, 47 .

Fulton, Mr., 38, IOI.

Gellet, Mr., 86.

Guides, 66.

Happiness, 7 .

Hobbies of fools, 27.

, great men, 20.

Hoppers, 6r.
Ideal birds, I5.

, fancier, 19.

Insects, 70.

Lock, Mr, , II2.

London, pigeons in, 34 .

"Making up" birds, 83 .

Martin, Mr., IIr.

Masters, Mr. , II2.

Megrims, 73.

Nature, religious side of, 5 .

Old masters on the brain, 27.

Ointment, $7 x$.

P's, the three, I6.

Parents, a word to, II6.

Pleasure of hand feeding, $6 \mathbf{z}$.

Picture Buyers, 27.

Pigeon dealers, I2.

, hobby, 6.

, in art, $3 \circ$.

" pedigree, 28.

, profitable, I3.

Queen Victoria, 38.

Redpath, Mr., 108.

Roman Fanciers, 3I.

Salt cat, 75 .

Strain, founding a, I7.

Secret of successful breeding, 18.

Towndrow, Mr., II2.

Ure, Mr., 17, 18, rg.

Venice, pigeons of, $5 \mathrm{I}$.

Ventilation, 67.

Wiltshire Rector, II6.

Windus, Mr., 80.

Woodhouse, Mr., 54, ro4. 
A Catalogue of American and Foreign Books Published or Imported by Messrs. Sampson Low \& Co. can be had on application.

Crowon Buildings, 188, Fleet Street, London, October, 1886.

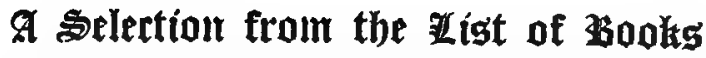

\author{
PUBLISHED EY \\ SAMPSON LOW, MARSTON, SEARLE, \& RIVINGTON.
}

ALPHABETICAL LIST.

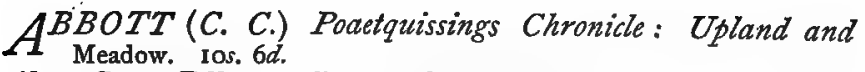
About Some Fellows. By an ETON Boy, Author of "A Day of my Life." Cloth limp, square $16 \mathrm{mo}, 2 s .6 d$.

Adams (C. K.) Manual of Historical Literature. Cr. 8vo, i2s. 6 d. Alcott (Louisa M.) Joe's Boys. ${ }^{5}$.

- Lulu's Library. 3s. 6d.

Old-Fashioned Thanksgiving Day. 3s. 6al.

- Proverb Stories. I6no, $3^{\text {s. } 6 d .}$

Spinning-Wheel Stories. $16 \mathrm{mo}, 5 s$.

- See also "Rose Library."

Alden (W. L.) Adventures of Jimmy Brozen, written by himiself. Illustrated. Small crown 8vo, cloth, 2s. $6 d$.

Aldrich (T. B.) Friar Jerome's Beautiful Book, Boc. Very choicely printed on hand-rnade paper, parchment cover, $3 s .6 d$.

Poetical Works. Edition de luxe. 8vo, $21 \mathrm{~s}$.

Alford (Lady Marian) Needlezerk as Art. With over Ioo Woodcuts, Photogravures, \&c. Royal 8vo, $42 s$; large paper, 845.

Amateur Angler's Days in Dove Dale: Three Weeks' Holiday in July and August, 1884. By E. M. Printed by Whittingham, at the Chiswick Press. Cloth gilt, $1 s .6 d$; ; fancy boards, $1 s$.

American Men of Letters. Thoreau, Irving, Webster. 2s. 6d. each. Andersen. Fairy Tales. With over 500 Illustrations by Scandinavian Artists. 6s. per vol.

Anderson $(W$ ) Pictoral Arts of Japan. With 80 full-page $\therefore \quad$ and other Plates, 16 of them in Colours. Large imp. 4 to, 81. 8s. (in four folio parts, 2l. 2s. each); Artist's Profofs, 12l, | $2 s$, 
Angler's Strange Experiences $(A n)$. By Cotswold Isvs. With numerous Illustrations, 4to, 55. New Edition, 3s. $6 d$. Angling. See Amateur, "British Fisheries," "Cutcliffe," "Halford," "Hamilton," "Martin," "Orvis," "Pennell," " Pritt,"

"Stevens," "Theakston," "Walton," "Wells," and "Willis-Bund." Arnold (Edzin) Birthday Book. 4s. 6d.

Art Education. See "Biographies of Great Artists," "Illustrated Text Books," "Mollett's Dictionary."

Artists at Home. Photographed by J. P. MaYalL, and reproduced in Facsimile. Letterpress by F. G. STEphens. Imp. folio, $42 s$. Audsley (G. A.) Omamental Arts of Fapan. 90 Plates, 74 in Colours and Gold, with General and Descriptive Text. 2 vols., folio, E15 15s.; in specally designed leather, $23 l$. $2 s$. The Art of Chromo-Lithography. Coloured Plates and Text. Folio, 63s.

Auerbach (B.) Brigitta. (B. Tauchnitz Collection.) 2s. On the Heights. 3 vols., $6 s$.

Spinoza. 2 vols., $18 \mathrm{mo}, 4 s$.

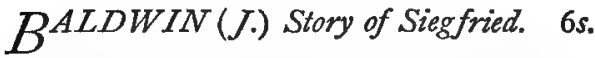

Story of Roland. Crown 8vo, $6 s$.

Barlow (Alfred) Weaving by Hand and by Power. With several hundred Illustrations. Third Edition, royal 8vo, 1 l. 5 s.

Barrow (J.) Mountain Ascents in Cumberland and Westmoreland. $7 s .6 d$.

Bassett (F.S.) Legends and Superstitions of the Sea and of Sailors. 7s. $6 d$.

\section{THE BAYARD SERIES.}

Edited by the late J. HAIN Friswell.

Comprising Pleasure Books of Literature produced in the Choicest Style as Companionable Volumes at Home and Abroad.

"We can hardly imagine better books for boys to read or for men to ponder over."-Times.

Price 2s. 6d. cach Volume, complete in itself, fexible cloth extra, gilt edges, with silk Headbards and Registers.

The Story of the Chevalier Bayard. Abdallah; or, The Four Leaves. By M. De Berville.

De Joinville's St. Louis, King of Table-Talk and Opinions of NaFrance.

The Essays of Abraham Cowley, in- Vathek: An Oriental Romance, cluding all his Prose Works. By William Beckford. 
Bayard Series (continued) :-

Words of Wellington : Maxims and Ballad Poetry of the Affections. By Opinions of the Great Duke.

Dr. Johnson's Rasselas, Prince of Abyssinia. With Notes.

Hazlitt's Round Table. With Biographical Introduction.

The Religio Medici, Hydriotaphia, and the Letter to a Friend. By Sir Thomas Browne, Knt.

Coleridge's Christabel, and other Imaginative Poems. With Preface by. Algernon C. Swinburne.

Lord Chesterfield's Letters, Sentences, and Maxims. With Introduction by the Editor, and Essay on Chesterfield by M. de Ste.-Beuve, of the French Academy.

Robert Buchanan.

The King and the Commons. A Selection of Cavalier and Puritan Songs. Edited by Professor Morley. Essays in Mosaic. By Thos. Ballantyne.

My Uncle Toby; his Story and his Friends. Edited by P. Fitzgerald.

Reflections; or, Moral Sentences and Maxims of the Duke de la Rochefoucauld.

Socrates: Memoirs for English Readers from Xenophon's Memorabilia. By Edw. Levien.

Prince Albert's Golden Precepts.

A Case containing 12 Volumes, price 3is. 6d.; or the Case separately, price $3 s .6 d$.

Behnke and Browne. Child's Voice. Small 8vo, 3s. $6 d$.

Beyschlag. Female Costume Figures of various Centuries. I2 designs in portfolio, imperial. 21s.

Bickersteth (Bishop E. H.) The Clergyman in his Home. Small post 8vo, is.

- Evangelical Churchmanship and Evangelical Eclecticism. 8vo, 1 s.

From Year to Year: Original Poetical Pieces. Small post $8 \mathrm{vo}, 3 s .6 d$.; roan, $6 s$. and $5 s$; calf or morocco, 10s. $6 d$.

Hymnal Companion to the Book of Common Prayer. May be had in various styles and bindings from $1 d$. to $31 s, 6 d$. Price List and Prospectus will be forwarded on application.

The Master's Home-Call; or, Brief Memorials of Alice

Frances Bickersteth. 2oth Thousand. 32mu, cloth gilt, Is.

- The Master's Will. A Funeral Sermon preached on the Death of Mrs. S. Gurney Buxton. Sewn, $6 d$; ; cloth gilt, is.

The Reef, and other Parables. Crown 8vo, 2s. 6d. The Shadow of the Rock. A Selection of Religious Poetry. $18 \mathrm{mo}$, cloth extra, $2 s .6 d$.

- The Shadowed Home and the Light Beyond. New

Edition, crown 8vo, cloth extra, 5 s. 
Biographies of the Great Artists (Illustrated). Crown 8vo, emblematical binding, $3 s$. $6 d$. per volume, except where the price is given.

Claude Lorrain.

Correggio, by M. E. Heaton, 2s. 6d.

Della Robbia and Cellini, 2s. $6 d$.

Albrecht Diirer, by R. F. Heath.

Figure Painters of Holland.

FraAngelico, Masaccio, and Botticelli.

Fra Bartolommeo, Albertinelli, and

Andrea del Sarto.

Gainsborough and Constable.

Ghiberti and Donatello, 2s. $6 d$.

Giotto, by IIarry Quilter.

Hans Holbein, by Joseph Cundall.

Hogarth, by Austin Dobson.

Landseer, by F. G. Stevens.

Lawrence and Romney, by Lord Ronald Gower, 2s, 6d.

Leonardo da Vinci.

Little Masters of Germany, by W. B. Scott.
Mantegna and Francia.

Meissonier, by J. W. Mollett, 2s. $6 d$. Michelangelo Buonarotti, by Clément. Murillo, by Ellen E. Minor, 2s. 6d. Overbeck, by J. B. Atkinson. Raphael, by N. D'Anvers.

Rembrandt, by J. W. Mollett. Reynolds, by F. S. Pulling. Rubens, by C. W. Kett. Tintoretto, by W. R. Osler. Titian, by R. F. Heath.

Turner, by Cosmo Monkhouse.

Vandyck and Hals, by P. R. Head.

Velasquez, by E. Stowe.

Vernet and Delaroche, by J. Rees. Watteau, by J. W. Mollett, 2s. $6 a$. Wilkie, by J. W. Mollett.

Bird $(F . J$.$) American Practical Dyer's Companion. 8 \mathrm{vo}, 42 s$. Bird (H. E.) Chess Practice. 8vo, 2s. 6d. Black (Robert) Horse Racing in France. 14s. Black (Wm.) Novels. See "Low's Standard Library."

Blackburn (Charles F.) Hints on Catalogue Tittes and Index Entries, with a Vocabulary of Terms and Abbreviations, chiefly from Foreign Catalogues. Royal 8vo, 14 s.

Blackburn (Henry) Breton Folk. With 17 I Illust. by RANDOLPH CALDECOTT. Imperial 8vo, gilt edges, 2Is; ; plainer binding, 10s. $6 d$. Pyrenees. With roo Illustrations by GUSTAVE DORE, corrected to 188r. Crown 8vo, 7s. 6a. See also CALDECOTr.

Blackmore (R.D.) Lorna Doone. Edition de luxe. Crown 4 to, very numerous Illustrations, cloth, gilt edges, 3Is. 6d.; parchment, uncut, top gilt, 35s.; new issue, plainer, 21 s.; small post $8 \mathrm{vo}, 6 s$.

Novels. See "Low's Standard Library."

Blaikie (Willian) How to get Strong and how to Stay so. Rational, Physical, Gymnastic, \&c., Exercises. Illust., sm. post 8vo, 5s." Bonnound Bodies for our Boys and Girls. $16 \mathrm{mo}, 2 s .6 d$. Bonzeick. British Colonies. Asia, Is.; Africa, I $s_{0}$; America, Is. ; Australasia, Is. One vol., 5 s.

Besanquet (Rev. C.) Blossoms from the King's Garden : Sermons for Children, 2nd Edition, small post $8 v$ vo, cluth extra, $6 s$. - Jahioshaphat; or, Sunlight and Clouds. Is. 
Boulton (Major) North-West Rebellion in Canada. $9 s$. Boussenard (L.) Crusoes of Guiana. Illustrated. ${ }_{5}$ s. Gold-seekers, a Sequel. Illustrated. $16 \mathrm{mo}, 5 s$.

Bowker (R. R.) Copyright: its Law and its Literature. I 5 s. Boyesen (F.) Story of Norway. $7 s .6 d$.

Boy's Froissart. King Arthur. Mabinogion. Percy. See LANIER.

Bradshaw $(J$.) New Zealand as it is. 8vo, r2s. 6 d.

Brassey (Lady) Tahiti. With 3I Autotype Illustrations after Photos. by Colonel Stuart-Wortley. Fcap. 4to, 21 s.

Bright (John) Public Letters. Crown 8vo, 7 s. 6d.

Brisse (Baron) Ménus (366). A ménu, in French and English,

for every Day in the Year. Translated by Mrs. MatTheW ClarkE.

2nd Edition. Crown 8vo, 5 s.

British Fisheries Directory, $1883-84$. Small 8vo, 2s. 6d.

Brittany. See BlaCKBURN.

Britons in Brittany. By G. H. F. 2s. 6 d.

Brown. Life and Letters of John Brown, Liberator of Kansas, and Martyr of Virginia. By F. B. SANBoRn. Illustrated. 8vo, 12s.6d. Browne (G. Lennox) Voice Use and Stimulants. Sm. 8vo, 3s. $6 d$.

3s. and Behnke (Emil) Voice, Song, and Speech. Illustrated, 3re Edition, medium 8vo, $15 s$.

Bryant (W. C.) and Gay (S. H.) History of the United States. 4 vols., royal $8 \mathrm{vo}$, profusely Illustrated, 6os.

Bryce (Rev. Professor) Manitoba. With Illustrations and Maps. Crown 8vo, 7s. 6\%.

Bunyan's Pilgrim's Progress. With 138 original Woodcuts. Small post 8vo, cloth gilt, $2 s .6 d$; gilt edges, $3 s$.

Burnaby (Capt.) On Horseback through Asia Minor. 2 vols., 8vo, $38 s$. Cheaper Edition, I vol., crown 8vo, Ios. $6 \mathrm{~d}$.

Burnaby (Mrs. F.) High Alps in Winter; or, Mountaineering in Search of Health. By Mrs. Fred BuRNaBY. With Portrait of the Authoress, Map, and other Illustrations. Handsome cloth, 14s.

Butler (W. F.) The Great Lone Land; an Account of the Red River Expedition, 1869-70. New Edition, cr. 8vo, cloth extra,7s. 6d. Invasion of England, told twenty years after, by an Old Soldier. Crown 8vo, $2 s .6 d$.

- Red Cloud; or, the Solitary Sioux. Imperial I6mo, ; numerous illustrations, gilt edges, 5 s.

with Dogs across Northern North America. 8va, $18 s_{*}$ Cr. 8vo, $7 s_{\mathrm{s}} 6 \%$. 
CADOGAN (Lady A.) Illustrated Games of Patience.

Twenty-four Diagrams in Colours, with Text. Fcap. 4to, 12s. $6 d$.

Caldecott (Randolph) Memoir. By HenRY BLACKBURN. With I70 (chiefly unpublished) Examples of the Artist's Work. I4s.; large paper, $21 s$.

California. See NordHOFF.

Cambridge Staircase $(A)$. By the Author of "A Day of my Life at Eton." Small crown 8vo, cloth, 2s. 6d.

Cambridge Triftes; from an Undergraduate $P e n$. By the Author of "A Day of my Life at Eton," \&c. I6mo, cloth extra, 2s. 6d.

Campbell (Lady Colin) Book of the Running Brook: and of still Waters. 5 s.

Canadian People: Short History: Crown 8vo, 7s. 6d.

Carleton (Will) Farm Ballads, Farm Festivals, and Farm

Legends. I vol., small post $8 \mathrm{vo}, 3 s .6 d$.

- City Ballads. With Illustrations. I2s. 6d. See also "Rose Library."

Carnegie (A.) American Frour-in-Hand in Brilain. Small 4to, Illustrated, IOs. 6d. Popular Edition, is.

- Round the World. 8vo, ros. $6 d$.

Triumphant Democracy. 6s.; also is. 6d. and is.

Chairman's Handbook (The). By R. F. D. PaLGRave, Clerk of the Table of the House of Commons. 5th Edition, 2s.

Changed Cross (The), and other Religious Poems. $16 \mathrm{mo}, 2 s .6 d$; calf or inorocco, $6 s$.

Charities of London. See Low's.

Chattock (R.S.) Practical Notes on Etching. 8vo, ros. 6d. Chess. See BIRD (H. E.).

Children's Praises. Hymns for Sunday-Schools and Services. Compiled by Louisa H. H. Tristram. $4 d$.

Choice Editions of Choice Books. 2s. 6 d. . each. Illustrated by C. W. COPE, R.A., T. CRESWICK, R.A., E. DUNCAN, BIRKET FOSTER, J. C. HORSLEY, A.R.A., G. HICKS, R. REDGRAVE, R.A., C. STONEHOUSE, F. TAYLeR, G. THOMAS, H. J. TOWNSHEND, E. H. WEHNERT, HARRISON WEIR, \&c.

Bloomfield's Farmer's Boy.

Campbell's Pleasures of Hope.

Coleridge's Ancient Mariner.

Goldsmith's Deserted Village.

Goldsmith's Vicar of Wakefield.

Gray's Elegy in a Churchyard.

Keat's Eve of St. Agnes. Millon's L'Allegro. Poetry of Nature. Harrison Weir. Rogers' (Sam.) Pleasures of Memory. Shakespeare's Songs and Sonnets. Tennyson's May Queen. Elizabethan Poets. Wordsworth's Pastoral Poems.

"Such works are a glorious beatification for a poet." 
Christ in Song. By Philip Schaff. New Ed., gilt edges, $6 s$. Chromo-Lithography. See AunsLEY.

Collingwood (Harry) Under the Meteor Flag. The Log of a Midshipman. Illustrated, small post $8 \mathrm{vo}$, gilt, $6 s$; ; plainer, $5 s$.

- The Voyage of the "Aurora." Illustrated, small post $8 \mathrm{vo}$, gilt, 6s.; plainer, 5 s.

Composers. See "Great Musicians."

Cook (Dutton) Book of the Play. New Edition. I vol., 3s. $6 d$. On the Stage: Studies of Theatrical History and the Actor's Art. 2 vols., 8 vo, cloth, 24 s.

Cowen (Jos., M.P.) Life and Speeches. By Major Jones. $8 \mathrm{vo}, \mathrm{I4s.}$

Cozzens (F.) American Yachts. 27 Plates, $22 \times 28$ inches. Proofs, 2Il.; Artist's Proofs, 3Il. ros.

Crowen Prince of Germany: a Diary. $7 s .6 d$.

Cundall (Joseph) Annals of the Life and Work of Shakespeart. With a List of Early Editions. 3s. 6d.; large paper, 5 s.

Cushing $(W$.$) Initials and Pseudonyms: a Dictionary of Literary$ Disguises. Large $8 \mathrm{vo}$, top edge gilt, $2 \mathrm{~s}$.

Custer (E. B.) Boots and Saddles. Life in Dakota with General Custer. Crown 8vo, 8s.6d.

.Cutclife (H.C.) Trout Fishing in Rapid Streams. Cr. 8vo,3s. $6 d$ DANVERS (N.) An Elementary History of Art. Crown
8vo, 10s. 6d.

- Elementary History of Music. Crown 8vo, 2s. $6 d$. Handbooks of Elementary Art-Architecture; Sculpture; Old Masters; Modern Painting. Crown 8vo, 3s. 6d. each.

Davis (Clement) Modern Whist. 4 s.

Davis (C. T.) Manufacture of Bricks, Tiles, Terra-Cotta, Eoc. Illustrated. $8 \mathrm{vo}, 25$ s.

- Manufacture of Leather. With many Illustrations. $52 s .6 \mathrm{~d}$. Manufacture of Paper. 28 s.

Dawidowsky $(F$.) Glue, Gelatine, Isinglass, Cements, \&oc. 8vo, I2s. 6 d.

Day of My Life $(A)$; or, Every-Day Experiences at Eton. By an Eton Box. I6mo, cloth extra, 2s. $6 d$.

Day's Collacon: an Encyclopiedia of Prose Quotations. Imperial 8vo, cloth, $31 s .6 d$.

Decoration. Vols. II. to XI. New Series; folio, 7s. 6d. each. 
Dogs in Disease : their Management and Treatment. By AsHMONT. Crown 8vo, 7s. $6 d$.

Donnelly (Ignatius) Atlantis; or, the Antediluvian World. 7 th Edition, crown 8vo, 12s. $6 d$.

- Ragnarok: The Age of Fire and Gravel. Illustrated, crown 8 vo, I2s. $6 d$.

Doré (Gustave) Life and Reminiscences. By Blanche RooseVELT. With numerous Illustrations from the Artist's previously unpublished Drawings. Medium 8vo, 24 s.

Dougall (James Dalziel) Shooting: its Appliances, Practice, and Purpose. New Edition, revised with additions. Crown 8vo, 7s. 6d.

"The book is admirable in every way. ... . We wish it every success." -Globe.

"A very complete treatise. . . . Likely to take high rank as an authority on shooting."-Daily Nezs.

Drama. See Cook (Dutron).

Dyeing. See BIRD (F. J.).

Dunn (J.R.) Massacres of the Mountains: Indian Wars of the Far West. 2Is.

Duprè (Giovanni). By H. S. Frieze. With Dialogues on Art by Augusto Conti. 7 s. $6 d$.

\section{FDUCATIONAL List ana Directory for $1886-87.5$ s.}

Educational Works published in Great Britain. A Classified Catalogue. Second Edition, 8vo, cloth extra, 5 s.

Egypt. See "Foreign Countries."

Eight Months on the Gran Chaco of the Argentine Republic. $8 \mathrm{vo}, 8 s .6 d$.

Electricity. See GoRdon.

Elliott (H. W.) An Arctic Province: Alaska and the Seal

Islands. Illustrated from Drawings; also with maps. I6s.

Ellis (W.) Royal Jubilees of England. 35. $6 d$.

Emerson (Dr. P. H.) and Goodall. Life and Landscape on

the Norfolk Broads. Plates $12 \times 8$ inches (before publication, I05s.), $126 s$.

Emerson (R. W. Life. By G. W. Cooke. Crown 8vo, 8s. 6d. English Catalogue of Books. Vol. III., I872-I880. Royal $8 v o$, half-morocco, $42 s$. See also "Index."

English Etchings. . A Periodical published Quarterly. 3s. 6d. 


\section{English Philosophers. Edited by E. B. Ivan Müller, M.A.}

A series intended to give a concise view of the works and lives of English thinkers. Crown 8vo volumes of 180 or 200 pp., price $3 s$. $6 d$. each.

Francis Bacon, by Thomas Fowler. |*John Stuart Mill, by Miss Helen Hamilton, by W. H. S. Monck.

Hartley and James Mill, by G. S. Bower.

Taylor.

Shaftesbury and Hutcheson, by Professor Fowler.

Adam Smith, by J. A. Farrer.

- Not yet published.

Etching. See Chattock, and English Etchings. Etchings (Modern) of Celebrated Paintings. 4to, 3rs. 6d.

FARINI (G. A.) Through the Kalahari Desert: Fauna, Flora, and Strange Tribes, $21 s$.

Farn Ballads, Festivals, and Legends. See "Rose Library."

Fauriel (Claude) Last Days of the Consulate. Cr. 8vo, Ios. 6:2.

Fazucett (Edgar) A Gentleman of Leisure. Is.

Federighi. Seven Ages of Man. Lithographs from Drawings, 7 plates. 25 s.

Feilden (H. St. C.) Some Public Schools, their Cost and

Scholarships. Crown 8vo, 2s. 6d.

Fenn (G. Manville) Off to the Wilds: A Story for Boys.

Profusely Illustrated. Crown 8vo, 7s. 6d. ; also $5 s$.

- The Silver Cañon: a Tale of the IVestern Plains.

Illustrated, small post $8 \mathrm{vo}$, gilt, 6 s.; plainer, 5 s.

Fennell (Greville) Book of the Roach. New Edition, I 2mo, $2 s$. Ferns. See Heath.

Field (H. M.) Greek Islands and Turkey after the War. 8s. $6 d$. Fields (J.T.) Yesterdays with Authors. New Ed., 8vo, Ios. $6 d$. Fitzgerald (Percy) Book Fancier: Romance of Book Collecting.

Fleming (Sandford) England and Carada: a Summer Tour. Crown 8vo, $6 s$.

Florence. See YRIARTE.

Folkard (R., Jun.) Plant Lore, Legends, and Lyrics. Illustrated, $8 \mathrm{vo}, 16 s$. 
Forbes ( $H$. O.) Naturalist's Wanderings in the Eastern Archi. pelago. Illustrated, $8 \mathrm{vo}, 2 \mathrm{Is}$.

Foreign Countries and British Colonies. A series of Descriptive Handbooks. Crown 8vo, 3s. $6 a$. each.

Australia, by J. F. Vesey Fitzgerald. | Peru, by Clements R. Markham, Austria, by D. Kay, F.R.G.S.

*Canada, by W. Fraser Rae.

Denmark and Iceland, by E. C.Otté. Egypt, by S. Lane Poole, B.A. France, by Miss $M$. Roberts.

Germany, by S. Baring-Gould. Greece, by L. Sergeant, B.A.

*Holland, by R. L. Poole. Japan, by S. Mossman.

* New Zealand.

*Persia, by Major-Gen. Sir F. Goldsnid. C B.

Russia, by W. R. Morfill, M.A. Spain, by Rev. Wentworth Webster. Sweden and Norway, by F. H. Woods.

*Switzerland, by W. A. P. Coolidge, M.A.

*Turkey-in-Asia, by J. C. McCoan, M.P.

West Indies, by C. H. Eden, F.R.G.S.

* Not ready yct.

Fortnight in Heaven: an Unconventional Romance. $3^{s .6 d}$. Fortunes made in Business. Vols. I., II., III. I6s. each. Frampton (Mary) Journal, Letters, and Anecdotes, I7991846. $8 \mathrm{vo}, 14 s$.

Franc (Maud Jeanne). The following form one Series, small post $8 \mathrm{vo}$, in uniform cloth bindings, with gilt edges :-

Emily's Choice. $5 s$.

Hall's Vineyard. $4 s$.

John's Wife: A Story of Life in

South Australia. $4 s$.

Marian; or, The Light of Some

One's Home. $5^{5}$.

Silken Cords and Iron Fetters. $4 s$.

Into the Light. $4 s$.

Vermont Vale. $5 s$.

Minnie's Mission. 4s.

Little Mercy. 4s.

Beatrice Melton's Discipline. 4s.

No Longer a Child. 4 s.

Golden Gifts. 45 .

Two Sides to Every Question. 4s. Master of Ralston. $4 s$.

Frank's Ranche; or, My Holiday in the Rockies. A Contribution to the Inquiry into What we are to Do with our Boys. 5 s.

French. See Julien.

Froissart. See LANIE?.

Fuller (Edward) Fellowe Travellers. 3s. 6d.

GALE (F.; the Old Buffer) Modern English Sports: their Use and Abuse. Crown 8vo, 6s.; a few large paper copies, ros. $6 d$. Galloway (W.B.) Chalk and Flint Formation. 2s, 6d. 
Gane (D. N.) Neze South Wales and Victoria in $1885 . \quad 5$ s. Geary (Grattan) Burma after the Conquest. 7s. $6 d$. Gentle Life (Queen Edition). 2 vols. in I, small 4to, $6 s$.

\section{THE GENTLE LIFE SERIES.}

Price 6s. each ; or in calf extra, price ros. $6 \%$; Smaller Edition, cloth extra, $2 s .6 d$., except where price is named.

The Gentle Life. Essays in aid of the Formation of Character of Gentlemen and Gentlewomen.

About in the World. Essays by Author of "The Gentle Life." Like unto Christ. A New Translation of Thomas à Kempis' "De Imitatione Christi."

Familiar Words. An Index Verborum, or Quotation Handbook. 6s.

Essays by Montaigne. Edited and Annotated by the Author of "The Gentle Life."

The Gentle Life. and Series.

The Silent Hour: Essays, Original and Selected. By the Author of "The Gentle Life."

Half-Length Portraits. Short Studies of Notable Persons. By J. HAIN FRISWELL.

Essays on English Writers, for the Self-jmprovement of Students in English Literature.

Other People's Windozes. By J. Hain Friswell. $6 s$. A Man's Thoughts. By J. HaIN Friswell.

The Countess of Pembroke's Arcadia. By Sir Philip Sidney. New Edition, 6s.

George Eliot: a Critical Study of her Life. By G. W. Cook E. Crown 8 vo, 1os. $6 d$.

Germany. By S. Baring-Gould. Crown 8vo, 3s. $6 d$. Gilder (W. H.) Ice-Pack and Tundra. An Account of the Search for the "Jeannette." 8vo, $18 s$.

Schwatka's Search. Sledging in quest of the Franklin Records. Illustrated, 8vo, I2s. 6d.

Gisborne (W.) Neze Zealand Rulers and Statesmen. With Portraits. Crown 8vo, $7 s .6 d$. 
Gordon (General) Private Diary in China. Edited by S. Mossman. Crown 8vo, 7s. 6d.

Gordon (T. E. H., B.A. Cantab.) Four Lechures on Electric Induction at the Royal Institution, I878 9. Illust., square $16 \mathrm{mo}, 3$ s. Electric Lighting. Illustrated, 8vo, I8s. Physical Treatise on Electricity and Magnetism. 2nd

Edition, enlarged, with coloured, full-page, \&c., Illust. 2 vols., 8vo, $42 s$. Electricity for Schools. Illustrated. Crown 8vo, 5 s.

Gouffé (Jules) Royal Cookery Book. Translated and adapted for English use by Alphonse Gouffé, Head Pastrycook to the Queen. New Edition, with plates in colours, Woodcuts, \&c., 8vo gilt erlges, $42 s$.

- Domestic Edition, half-bound, ros. $6 d$.

Grant (General, U.S.) Personal Memoirs. With numerous

Illustrations, Maps, \&c. 2 vols., 8vo, 28 s.

Great Artists. See "Biographies."

Great Musicians. Edited by F. HuEfrer. A Series of Biographies, crown Svo, 3 s. each :-

Bach.

*Beethoven.

* Berlioz.

English Church Com*Gliick.

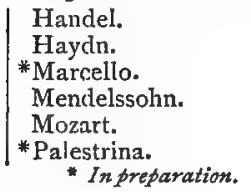

Purcell.

Rossini.

Schubert.

Schumann.

Richard Wagner.

Weber.

Greenwood (H.) Our Land Lawes as they are. 2s. 6d.

Grimm (Hermann) Literature. 8s. 6d.

Groves (J. Perry) Charmouth Grange : a Tale of the Seven-

teenth Century. Illustrated, small post $8 \mathrm{vo}$, gilt, $6 s$; ; plainer $5 s$.

Guizot's History of France. Translated by RoBerT BLACK.

Super-royal $8 \mathrm{vo}$, very numerous Full-page and other Illustrations. In 8 vols., cloth extra, gilt, each 24 s. This work is re-issued in cheaper binding, 8 vols., at ros. $6 d$. each.

"It supplies a want which has long been felt, and ought to be in the hands of all students of history."-Times.

Masson's School Edition. Abridged

from the Translation by Robert Black, with Chronological Index, Historical and Genealogical Tables, \&c. By Professor Gustave Masson, B. A. With 24 full-page Portraits, and other Illustrations. ' 1 vol,', $8 \mathrm{vo}, 600$ pp., ros. $6 \dot{ }$.

Guyon (Mde.) Life. By Upilam. 6th Edition, crown 8vo, 6s. 

HLFORD $(F . M$.$) Floating Flies, and hone to Dress them.$
Coloured plates. 8vo, 15 s.; large paper, 30 .

Hall (W.W.) How to Live Long; or, 1408 Health Maxims, Physical, Mental, and Moral. 2nd Edition, small post 8vo, 2s.

Hamilton (E.) Recollections of Fly-fishing for Salmon, Trout, and Grayling. With their Habits, Haunts, and History. Illustrated, small post 8vo, 6s.; large paper (100 numbered copies), Ios. $6 d$.

Hands (T.) Numerical Exercises in Chemistry. Cr. 8vo, 2s. 6d. and $2 s_{0}$; Answers separately, $6 d$.

Hardy (Thomas). See Low's Standard Novels.

Harland (Marian) Home Kitchen: a Collection of Practical and Inexpensive Receipts. Crown 8vo, 5 s.

Harley (T.) Southreard Hol to the State of Georgia. ${ }_{5}$ s.

Harper's Magazine. Published Monthly. r6o pages, fully Illustrated, Is. Vols., half yearly, I.-XII. (December, I880, to November, I886), super-royal 8vo, 8s. $6 \mathrm{~d}$. each.

" 'Harper's Magazine' is so thickly sown with excellent illustrations that to count them would be a work of time; not that it is a picture magazine, for the engravings illustrate the text after the manner seen in some of our choicest éditions de luxe." St. Fayses's Gazette.

"It is so pretty, so big, and so cheap. ... . An extraordinary shillingsworthI6o large octayo pages, with over a score of articles, and more than three times as many illustrations."-Edinburgh Daily Review.

"An amazing shillingsworth . . combining choice literature of both nations."Nonconformist.

Harper's Young People. Vols. I.-II., profusely Illustrated with woodculs and 12 coloured plates. Royal 4 to, extra binding, each $7 s .6 d$. ; gilt edges, 8s. Published Weekly, in wrapper, $1 d$. s mo. Annual Subscription, post free, $6 s .6 d$. ; Monthly, in wrapper, with coloured plate, $6 d$.; Annual Subscription, post free, $7 s .6 d$.

Harrison (Mary) Skilful Cook: a Practical Manual of Modern Experience. Crown 8vo, 5s.

Hatton (Frank) North Borneo. With Biography by JOSEPH HatTon. New Map, and Illustrations, I8s.

Hatton (Joseph) Journalistic London: with Engravings and Portraits of Distinguished Writers of the Day. Fcap. 4to, I2s. $6 d$.

Three Recruits, and the Girls they left behind them. Small post 8vo, $6 s$.

"It hurries us along in unflagging excitement." - Times.

Heath (Francis George) Fern World. With Nature-printed Coloured Plates. Crown 8vo, gilt edges, 12s. 6d. Cheap Edition, 6s. 
Heldmann (Bernard) Mutiny on Board the Slip "Lcander."

Small post 8vo, gilt edges, numerous Illustrations, 5 s.

Henty (G. A.) Winning his Spurs. Illustrations. Cr. 8vo, $5^{s .}$ Cornet of Horse: A Story for Boys. Illust., cr. 8vo, 5 s. Jack Archer: Tale of the Crimea. Illust., crown 8vo, $5^{5 .}$ - (Richmond) Australiana : My Early Life. $5^{5 .}$

Herrick (Robert) Poetry. Preface by Austin Dobson. With numerous Illustrations by E. A. AвBEY. 4to, gilt edges, 42.s.

Hicks (E. S.) Our Boys: How to Enter the Merchant Service. 5 s. Higginson (T.W.) Larger History of the United States. $\mathbf{I}_{4}$. Hill (Staveley, Q.C., M.P.) From Home to Home: Two Long Vacations at the Foot of the Rocky Mountains. With Wood Engravings and Photogravures. 8vo, 21 s.

Hitchman. Public Life of the Earl of Beaconsfield. $3^{5.6}$. Hofmann. Scenes from the Life of our Saviour. 12 mounted plates, $12 \times 9$ inches, $21 s$.

Holder (C. F.) Marvels of Animal Life. 8s. 6d. Ivory King: the Elephant and its Allies. Illus: trated. 8s. $6 d$.

Holmes (O. Wendell) Poetical Works. 2 vols., I $8 \mathrm{mo}$, exquisitely printed, and chastely bound in limp cloth, gilt tops, 10s. $6 d$. - Last Leaf : a Holiday Volume. $42 s$.

- Mortal Antipathy. 8s. 6d.

Homer, Iliad I.-XII., done into English Verse. By ARTHUR S. WAY. $9 s$.

Odyssey. Translated by A. S. WAX: 7s. $6 d$. Hore (Mrs.) To Lake Tanganyika in a Bath Chair. Portraits and maps.

Hundred Greatest Men (The). 8 portfolios, 2 Is. each, or 4 vols., half-morocco, gilt edges, 1o guineas. New Ed., I vol., royal 8vo, 21s. Hutchinson (T.) Diary and Letters. Vol. I., I6s.; Vol. II., I6s. Hygiene and Public Health. Edited by A. H. Buck, M.D. Illustrated. 2 vols., royal $8 \mathrm{vo}, 42 s$.

Hymnal Companion of Common Prayer. See BickersteTH. 
ILLUSTRATED Text-Books of Art-Education. Edited by EDWARD.J. POYNTER, R.A. . Each Volume contains numerous Illussations, and is strongly bound for Students, price 5s. Now ready :PAINTING.

Classicand Itaian. By PERCY French and Spanish. R. HEAD. English and American.

German, Flemish, and Dutch.

Classic and Early Christian.

ARCHITECTURE.

Gothic and Renainsance. By T. Roger SMTTH.

Antique: Egyptian and Greek. SCULPTURE.

Renaissance and Modern. By LEADER ScotT.

Index to the English Catalogue, Jan., 1874, to Dec., 1880. Royal 8vo, half-mcrocco, $18 s$.

Indian Garden Seris. See Robinson (PhiL.).

Irving (Henry) Impressions of America. By J. Hatton, 2 vols., 2Is.; New Edation, I vol., $6 s$.

Irving (Washington). Complete Library Edition of his Works in 27 Vols., Copyright, Unabridged, and with the Author's Latest Revisions, called the "Geoffrey Crayon" Edition, handsomely printed in large square 8vc, on superfine laid paper. Each volume, of about 500 pages, fully Illus.rated. 12s. $6 d$. per vol. See also "Little Britain." ("American Men of Letters.") 2s. $6 d$.

$\mathcal{F}$ AMES (C.) Cuniosities of Law and Lawyers. 8vo, 7 s. $6 d$

Japan. See Anderson, Audsley, also Morse.

Jerdon (Gertrude) Rey-hole Country. Illustrated. Crown 8vo, cloth, $5 s$.

Johnston (H. H.) River Congo, from its Mouth to Bolobo. New Edition, 8v), 2Is.

Jones (Major) Heroes of Industry. Biographies with Portraits. 7s. $6 d$.

United States. New Edition. 2s, $6 d$.

Julien (F.) English Student's French Examiner. 16mo, $2 s$.

- First Lessons in Conversational French Grammar. Crown 8vo, is.

- French at Home and at School. Book I., Accidence, \&c. Square crown $8 \mathrm{vo}, 2 s$. 
Julien (F.) Conversational French Reader. $x 6 \mathrm{mo}$, eloth, $25.6 d$ Petites Legeons de Conversation et de Grommaire. 3s. Phrases of Daily Use. Limp cloth, 6d Petites Leçons and Phrases. $35.6 d$.

$K^{E M P I S}$ (Thomas à) Daily Text-Book Square r6mo, 2s. 6d.; interleaved as a Birthday Book, 3s. a.d.

Kent's Conmentaries : an Abridgment for Siulents of American Law. By EDEN F. Thompson. Ios. $6 d$.

Kerr (W.M.) Far Interior: Cape of God Hope, across the Zambesi, to the Lake Regions. Illustrated Irom Sketches, 2 vols. $8 v 0,32 s$.

Kershaze (S. W. ) Protestants from France in their English Home. Crown 8va, 6s.

Kielland. Skipper Worsé. By the Earl of Ducie. Cr. 8vo, ros.6d. Kingston (W. H. G.) Works. Illustrajed, $16 \mathrm{mo}$, gilt edges, 7s. $6 d$.; plainer binding, plain edges, ${ }_{5} s$, eaci.

Heir of Kilfinnan.

Dick Cheveley.

Snow-Shoes and Canoes.

Kingsley (Rose) Children of Westminster Abbey: Studies in English History. 5 s.

Knight (E. F.) Albania and Montenegro. Illust. 8vo, 12s. $6 d$. Knight (E. J.) Cruise of the "Falcon." A Voyage to South America in a 30-Ton Yacht. Illust. New El. 2 vols., cr. 8vo, 24 s. Kunhardt. Small Yachts: Design and Cinstruction. 35 s.

LAMB (Charles) Essays of Elia. With over roo designs by C. O. MuRRAY. 6s.

Lanier's Works. Illustrated, crown $8 \mathrm{vo}$, gilt edges, $75.6 d$. each.

Boy's King Arthur.

Boy's Froissart.

Boy's Mabinogion; Original Welsh

Legends of King Arthur.

Boy's Percy: Ballads of Love and Adventure, selected from the "Reliques."

Lansdell (H.) Through Siberia. 2 vols., 8vo, 30s. I vol., ros. $6 d$. Russia in Central Asia. Illustrated. 2 vols, $42 s$.

Laxden $(W$.$) School Course on Heat. Second Edition, Illust. 5$ s. 
Leonardo da Vinci's Literary Works. Edited by Dr. JEAN PaUl Richter. Containing his Writings on Painting, Sculpture, and Architecture, his Philosophical Maxims, Humorous Writings, and Miscellaneous Notes on Personal Events, on his Contemporaries, on Literature, \&c. ; published from Manuscripts. 2 vols., imperial 8vo, containing about 200 Drawings in Autotype Reproductions, and numerous other Illustrations. Twelve Guineas.

Le Plongeon. Sacred Mysteries among the Mayas and the Quiches. 12s. 6u.

Library of Religious Poetry. Best Poems of all Ages. Edited by SCHAFF and Gilman. Royal 8vo, 2Is; ; cheaper binding, Ios. $6 d$.

Lindsay (W. S.) History of Merchant Shipping. Over 150 Illustrations, Maps, and Charts. In 4 vols., demy 8vo, cloth extra. Vols. I and 2 , IIs. each; vols. 3 and 4, I4s. each. 4 vols., 50 s.

Little Britain, The Spectre Bridegroom, and Legend of Sleeepy Hollow. By Washington Irving. An entirely New Edition de luxe. Illustrated by $\mathrm{I} 20$ very fine Engravings on Wood, by Mr. J. D. Cooper. Designed by Mr. Charles O. Murray. Re-issue, square crown $8 \mathrm{vo}$, cloth, $6 s$.

Low's Standard Library of Travel and Adventure. Crown 8vo, uniform in cloth extra, $7 s .6 d$., except where price is given.

I. The Great Ione Land. By Major W. F. ButLER, C.B.

2. The Wild North Land. By Major W. F. Butler, C.B.

3. How I found Livingatone. By H. M. STANLEY.

4. Through the Dark Continent. By H. M. Stanley. I2s. $6 d$.

5. The Threshold of the Unknown Region. By C. R. MARKHAM. (4th Edition, with Additional Chapters, IOs, 6t.)

6. Cruise of the Challenger. By W. J. J. SPRY, R.N.

7. Burnaby's On Horseback through Asia Minor. IOs. $6 d$.

8. Schweinfurth's Heart of Africa. 2 vols., $15 s$.

9. Marshall's Through America.

10. Lansdell's Through Siberia. Illustrated and unabridged, Ios, $6 d$.

Low's Standard Novels. Small post 8vo, cloth extra, 6s, each, unless otherwise stated.

A Daughter of Heth. By W. BLACK,

In Silk Attire. By W. BLACK.

Kilmeny. A Novel. By W. BLAck.

Lady Silverdale's Sweetheart. By W. BLACK.

Sunrise. By W. BLACK.

Three Feathers. By William Black.

Alice Iorraine. By R. D. BLACKMORE.

Christowell, a Dartmoor Tale. By R. D. BlACKMorE.

Clara Vaughan. By R. D. BLACKMORE. 


\section{Low's Standard Novels-continued.}

Cradock Nowell. By R. D. Blackmore.

Oripps the Carrier. By R. D. Blackmore.

Erema; or, My Father's Sin. By R. D. Blıckmore.

Lorna Doone. By R. D. Blackmore. 25 h Edition.

Mary Anerley. By R. D. BLACKMORE.

Tommy Upmore. By R. D. BLACKMORE.

An English Squire. By Miss Coreridge.

Some One झlse. By Mrs. B. M. Croker.

A Story of the Dragonnades. By Rev. E. Gilliat, M.A.

A Laodicean. By Thomas Hardy.

Far from the Madding Crowd. By Thomas Hardy.

Pair of Blue Eyes. By Thomas Hardy.

Return of the Native. By Thomas HARDY.

The Hand of Ethelberta. By Thomas HaRdy.

The Trumpet Major. By THOMas Hardy.

Two on a Tower. By ThOMAS Hardy.

Three Recruits. By Joseph HatToN.

A Golden Sorrow. By Mrs. Cashel Hocy. New Edition.

Out of Court. By Mrs. Cashel Hoey.

Don John. By JEAN Ingelow.

John Jerome. By Jean Ingelow. 5s.

Sarah de Berenger. By Jean Ingelow.

Adela Cathcart. By George Mac Donald.

Guild Court. By Grorge Mac Donald.

Mary Marston. By George Mac Donald.

Stephen Archer. New Ed, of "Gifts." By George Mac Donald.

The Vicar's Daughter. By George MaC Donald.

Weighed and Wanting. By GEORGe MAC DONALD.

Diane. By Mrs. MAcquond.

Elinor Dryden. By Mrs, Macquoid.

My Lady Greensleeves. By HeLen Mathers.

Alaric Spenceley. By Mrs. J. H. RiddeLL.

Daisies and Buttercups. By Mrs. J. H. Riddell.

The Senior Partner. By Mrs. J. H. RiddelL.

A Struggle for Fame. By Mrs. J. H. RiddelL.

Jack's Courtship. By W. ClARK Russell.

John Holdsworth. By W. Clark Russel.

A Sailor's Sweetheart. By W. ClarK Russell.

Sea queen. By W. CI.ARK Russell.

Watch Below. By W. Clark Russeld.

Strange Voyage. By W. Clark Russeld.

Wreck of the Grosvenor. By W. Clark Russeli.

The Lady Maud. By W. Clark Russell.

Iittle Loo. By W, ClaRK RuSSELI.

The Late Mrs. Irull. By Frank R. StockTon.

My Wife and I. By Mrs, Beecher Stowe.

Poganuc People, their Loves and Lives. By Mrs. B. STowe. 
Low's Standard Novels-continued.

Ben Hur: a Tale of the Christ. By Lew. Wallace.

Anne. By Constance Fentmore Woolson.

East Angels. By Constance Fenimore Woolson.

- For the Major. By Constance Fenimore Woolson. ${ }^{s}$.

French Feiress in her own Chateau.

Low's Handbook to the Charities of London. Edited and revised to date. Yearly, cloth, Is. 6d.; paper, Is. $M$ CCORMICK $(R$.$) . Voyages of Disconery in the Arctic and$ Sir John Franklin, \&c. With Maps and Lithos. 2 vols., royal 8vo, $52 s .6 d$.

MacDonald (G.) Orts. Small post 8vo, 6s. See also "Low's Standard Novels."

Mackay (Charles) Newe Glossary of Obscure Words in Shakespeare. $21 s$.

Matgregor (John) "Rob Roy" on the Baltic. 3rd Edition, small post $8 \mathrm{vo}, 2 s .6 d$; ; cloth, gilt edges, $3 s .6 d$.

A Thousand Miles in the "Rob Roy" Canoe. IIth Edition, small post $8 \mathrm{vo}, 2 s .6 d$.; cloth, gilt edges, $3 s .6 d$.

- Voyage Alone in the Yaul "Rob Roy." New Edition with additions, small post $8 \mathrm{vo}, 5 s . ; 3 s .6 d$. and $2 s .6 d$.

McLellan's Own Story: The War for the Union. Illustrations and maps. $18 s$.

Macquoid (Mrs.). See Low's STandard Novels.

Magazine. See Decoration, English Etchings, Harper.

Maginn (W.) Miscellanies: Prose and Verse. With Memoir. 2 vols., crown $8 \mathrm{vo}, 24$ s.

Main (Mrs.; Mrs. Fred Burnaby) High Life and Towers of Silence. Illustrated, square 8vo, ros. $6 d$.

Manitoba. See BRYCE.

Manning (E. F.) Deightful Thanes. Illustrated. $4^{\mathrm{to}}$, fancyboards, 5 s.

Markham (C. R.) The Threshold of the Unknown Region. Crown 8vo, with Four Maps. 4th Edition. Cloth extra, 10s. 6d.

-War between Perre and Chili, I879-188r. Third Ed. Crown 8vo, with Maps, 10s. $6 d$.

Marshall (W. G.) Through America. New Ed., cr. 8vo, 7s. 6d. 
Martin (F. W.) Float Fishing and Spinning in the Nottingham Style. New Edition. Crown 8vo, 2s. 6d.

Maury (Commander) Physical Geography of the Sed, and its Meteorology. New Edition, with Charts and Diagrams, cr. 8vo, 6s.

Men of Mark : a Gallery of Contemporary Portraits of the most Eminent Men of the Day, specially taken from Life. Complete in Seven Vols., 4to, handsomely bound, cloth, gilt edges, 25 s, each.

Mendelssohn Family (The), I729-1847. From Letters and Joumals. Translated. New Edition, 2 vols., 8vo, 30 s.

Mendelssohn. See also "Great Musicians."

Merrifield's Nautical Astronomy. Crown 8vo, 7s. 6d.

Merrylees (J.) Carlsbad and its Environs. 7s. 6d.; roan, $9 s$. Mitchell (D. G.; Ik. Marvel) Works. Uniform Edition, small 8vo, 5s. each.

Bound together.

Doctor Johns.

Dream Life.

Out-of-Town Places.
Reveries of a Baclielor.

Seven Stories, Basement and Attic.

Wet Days at Edgewood.

Mitford (Mary Russell) Our Village. With I 2 full-pape and 157 smaller Cuts. Cr. 4to, cloth, gilt edges, $2 \mathrm{I} s$; ; cheaper binding, $10 s .6 \mathrm{~d}$. Milford (P.) Ned Stafford's Experiences in the United States. 5 s. Mollett $(J . W$.$) Illustrated Dictionary of Words used in Art and$ Archæology. Terms in Architecture, Arms, Bronzes, Christian Art, Colour, Costume, Decoration, Devices, Emblems, Heraldry, Lace, Personal Ornaments, Pottery, Painting, Sculpture, \&c. Small 4to, 15 s. Money (E.) The Truth about America. $5^{\text {s. }}$

Morley (H.) English Literature in the Reign of Victoria. 200oth volume of the Tauchnitz Collection of Authors. $18 \mathrm{mo}, 2 s .6 \mathrm{~d}$. Morse (E. S.) Japanese Homes and their Surroundings. With more than 300 Illustrations. 21s.

Morwood. Our Gipsies in City, Tent, and Van. 8vo, r8s. Moxley. Barbados, West Indian Sanatorium. $3^{s .} 6 d$. Muller (E.) Noble Words and Noble Deeds. 7s. 6d.; plainer binding, $5 s$.

Murray (E.C. Grenville) Memoirs. By his widow, Comtesse DE RETHEL D'ARAGon.

Music. See "Great Musicians."

Mustard Leaves: Glimpses of London Society. By D.T.S. $3^{\text {s. } 6 d .}$ 
NAPOLEON and Marie Louise: Memoirs. By Madame DURAND. $7 s .6 d$.

Nere Zealand. See Bradshaw.

Nere Zealand Rulers and Slatesmen. See Gisborne.

Nicholls (J. H. Kerry) The King Country: Explorations in New Zealand. Many Illustrations and Map. New Edition, 8vo, 21s. Nordhoff (C.) California, for Health, Pleasure, and Residence. New Edition, 8vo, with Maps and Illustrations, $12 s .6 d$.

Northbrook Gallery. Edited by LORD Ronald Gower. 36 Permanent Photographs. Imperial 4to, 63s.; large paper, 105s.

Nott (Major) Wild Animals Photographed and Described. 35 s. Nursery Playmates (Prince of). 217 Coloured Pictures for Children by eminent Artists. Folio, in coloured boards, $6 s$.

O'BRIEN (R. B.) Fifty Years of Concessions to Ireland. With a Portrait of T. Drummond. Vol. I., I6s., II., I6s.

Orient Line Guide Book. By W. J. LofTIE. 5 s.

Orvis (C. F.) Fishing with the Fly. Illustrated. 8vo, r 2s. 6d. Our Little Ones in Heaven. Edited by the Rev. H. Robbins. With Frontispiece after Sir JoshUA Reynolds. New Edition, $5 \mathrm{~s}$.

Outing : Magazine of Outdoor Sports. Is. Monthly.

Owen (Douglas) Marine Insurance Notes and Clauses. New Edition, 145 .

PALLISER (Mrs.) A History of Lace. New Edition, with additional cuts and text. $8 \mathrm{vo}$, $21 s$.

The China Collector's Pocket Companion. With upwards of rooo Illustrations of Marks and Monograms. Small 8vo, 5 . Pascoe (C. E.) London of To-Day. Illust., crown 8vo, $3^{s .6} 6$. Payne (T. O.) Solomon's Temple and Capitol, Ark of the Flood and Tabernacle (four sections at 24s.), extra binding, 105s.

Pennell (H. Cholmondeley) Sporting Fish of Great Britain. 15s. ; large paper, 30 s.

Pharmacopocia of the United States of America. 8vo, 21 s. 
Martin (F. W. .) Float Fishing and Spinning in the Nottinghan Style. New Edition. Crown 8vo, 2s. 6d.

Maury (Commander) Physical Geography of the Sea, and its Meteorology. New Edition, with Charts and Diagrams, cr. 8vo, 6s.

Men of Mark: a Gallery of Contemporary Portraits of the most Eminent Men of the Day, specially taken from Life. Complete in Seven Vols., 4to, handsomely bound, cloth, gilt edges, 25. each.

Mendelssohn Family (The), I729-1847. From Letters and Journals. Translated. New Edition, 2 vols., 8vo, $30 s$.

Mendelssohn. See also "Great Musicians."

Merrifield's Nautical Astronomy. Crown 8vo, 7s. 6d.

Merrylees (J.) Carlsbad and its Environs. 7s. 6d.; roan, 9s.

Mitchell (D. G.; Ik. Marvel) Works. Uniform Edition, small $8 \mathrm{vo}, 5$ s. each.

Bound together.

Doctor Johns.

Dream Life.

Out-of-Town Places.

Reveries of a Bachelor.

Seven Stories, Basement and Attic.

Wet Days at Edgewood.

Mitford (Mary Russell) Our Village. With 12 full-pape and 157 smaller Cuts. Cr. 4to, cloth, gilt edges, $21 s$.; cheaper binding, 10s. $6 d$. Milford $(P$.$) Ned Stafford's Experiences in the United States. 5$ s. Mollett (J.W.) Illustrated Dictionary of Words used in Art and Archæoology. Terms in Architecture, Arms, Bronzes, Christian Art, Colour, Costume, Decoration, Devices, Emblems, Heraldry, Lace, Personal Ornaments, Pottery, Painting, Sculpture, \&cc. Small 4to, 15s. Money (E.) The Truth about America. $5^{\text {s. }}$

Morley (H.) English Literature in the Reign of Victoria. 2000th volume of the Tauchnitz Collection of Authors. $18 \mathrm{mo}, 2 s .6 \mathrm{~d}$. Morse (E. S.) Japanese Homes and their Surroundings. With more than 300 Illustrations. 21 s.

Morwood. Our Gipsies in City, Tent, and Van. 8vo, 18s. Moxley. Barbados, West Indian Sanatorium. 3s. $6 d$. Muller(E.) Noble Words and Noble Deeds. 7s.6d.; plainer binding, 5 s.

Murray (E. C. Grenville) Memoirs. By his widow, Comtesse de Rethel D'Aragon.

Music. See "Great Musicians."

Mustard Leaves: Glimpses of London Society. By D.T.S. 35.6d. 
NAPOLEON and Marie Louise: Memoirs. By Madame DURAND. 7s. $6 d$.

Nere Zealand. See Bradshaw.

Nero Zealand Rulers and Statesmen. See Gisborne.

Nicholls (J. H. Kerry) The King Country: Explorations in New Zealand. Many Illustrations and Map. New Edition, 8vo, 2Is. Nordhoff (C.) California, for Health, Pleasure, and Residence. New Edition, 8vo, with Maps and Illustrations, I2s. $6 d$.

Northbrook Gallery. Edited by LoRd Ronald Gower. 36 Permanent Photographs. Imperial 4to, 63s.; large paper, 105s.

Nott (Major) Wild Animals Photographed and Described. 35 s. Nursery Playmates (Prince of). 217 Coloured Pictures for Children by eminent Artists. Folio, in coloured boards, 6s.

$O^{\prime} B R I E N(R . B$.$) Fifty Years of Concesstons to Ireland.$ With a Portrait of T. Drummond. Vol. I., I6s., II., $16 s$.

Orient Line Guide Book. By W. J. LofTIE. 5 s.

Orvis (C. F.) Fishing with the Fly. Illustrated. 8vo, r2s. 6d. Our Little Ones in Heaven. Edited by the Rev. H. Robeins. With Frontispiece after Sir JoshuA Reynolds. New Edition, 5 s.

Outing: Magazine of Outdoor Sports. Is. Monthly.

Owen (Douglas) Marine Insurance Notes and Clauses. New Edition, 14 s.

PALLISER (Mrs.) A History of Lace. New Edition, with additional cuts and text. $8 \mathrm{vo}, 2 \mathrm{r} s$.

The China Collector's Pocket Companion. With upwards of 1000 Illustrations of Marks and Monograms. Small 8vo, 5 s. Pascoe (C. E.) London of To-Day. Illust., crown 8vo, $3 s .6 d$. Payne (T. O.) Solomon's Temple and Capitol, Ark of the Flood and Tabernacle (four sections at 24s.), extra binding, ro5s.

Pennell (H. Cholmondeley) Sporting Fish of Great Britain. 15 s. ; large paper, 30s.

Pharmacopceia of the United States of America. 8vo, $2 \mathrm{Is}$. 
Rose Library (The)-continued.

My Study Windows. By J. R. LOwELL.

The Guardian Angel. By Oliver Wendell Holmes.

My Summer in a Garden. By C. D. Warner.

Dred. By Mrs. Beecher Stowe. 2s.; cloth gilt, 3s. $6 d$.

Farm Ballads. By Will Carleton.

Farm Festivals. By Will Carleton.

Farm Legends. By Will. Carleton.

Farm Ballads : Festivals and Legends, One vol, cloth, 3s. 6d,

The Clients of Dr. Bernagius. 3s. 6d.; 2 parts, Is. each.

The Undiscovered Country. By W. D. Howells. 3 s. $6 d$, and Is.

Baby Rue. By C. M. Clay. 3s. 6d. and Is.

The Rose in Bloom. By L. M. AIcotT. 2s. ; cloth gilt, $3 s .6 d$.

Eight Cousins. By L. M. AlCotr. 2s. ; cloth gilt, 3s. $6 \mathrm{~d}$.

Onder the Lilacs. By L. M. AlcotT, 2s.; also 3s. 6al.

Silver Pitchers. By Louisa M. Alcott. Cloth, 3s. $6 d$.

Jemmy's Cruise in the "Pinafore," and other Tales. By Lovisa M. A LCOTT. 2s.; cloth gilt, $3 s .6 d$.

Jack and Jill. By LouisA M. AlcotT. 2s.; Illustrated, 5 s,

Hitherto. By the Author of the "Gayworthys." 2 vols., Is. each; I vol., cloth gilt, 3 s. $6 d$.

A Gentleman of Leisure. A Novel. By Edgar Fawcett. is. The Story of Helen Troy. Is.

Ross (Mars) and Stonehezerer Cooper. Highlands of Cantabria; or, Three Days from England. Illustrations and Map, 8vo, $21 s$.

Round the Yule Log: Norwegian Folk and Fairy Tales. Translated from the Norwegian of P. CHR. AsBjörnsen. With 100 Illustrations after drawings by Norwegian Artists, and an Introduction by $\mathrm{E}$. W. Gosse. Impl. $16 \mathrm{mo}$, cloth extra, gilt edges, $7 s .6 d$. and $5 s$.

Rousselet (Louis) Son of the Constable of France. Small post $8 \mathrm{vo}$, numerous Illustrations, 5 s.

King of the Tigers : a Story of Central India. Illustrated. Small post $8 \mathrm{vo}$, gilt, 6s.; plainer, 5 s.

Drummer Boy. Illustrated. Small post 8vo, $5 s$.

Rowubotham (F.) Trip to Prairie Land. The Shady Side of Emigration. 5s. 
Russell (W. Clark) Jack's Courtship. 3 vols., $3^{\text {Is. }} 6$ 6 .; 1 vol., $6 s$.

The Lady Maud. 3 vols., 31s. 6d.; I vol., 6s.:

- Sea Queen. 3 vols., 31 s. 6d.; I vol., 6s.

Strange Voyage. 3Is. $6 d$.

- Little Loo. 6 s.

- My Watch Below. 6s.

English Channel Ports and the Estate of the East and West India Dock Company. Crown 8vo, is.

- Sailor's Language. Illustrated. Crown 8vo, 3s. 6d.

sewed, $6 d$. Wreck of the Grosvenor. Small post 8vo, 6s.; 4 to, See also Low's Standard Novels.

SAINTS and their Symbols: A Companion in the Churches and Piclure Galleries of Europe. Illustrated. Royal $16 \mathrm{mo}, 3 s .6 d$.

Salisbury (Lord) Life and Speeches. By F. S. Pulling, M.A. With Photogravure Portrait of Lord Salisbury. 2 vols., cr. 8vo, 2Is. Sandilands ( . P.) How to Develop Vocal Power. Is.

Saunders (A.) Our Donestic Birds: Poultry in England and New Zealand. Crown 8vo, $6 s$.

- Our Horses: the Best Muscies controlled by the Best Brains. $6 s$.

Scherr (Prof. F.) History of English Literature. Cr. 8vo, 8s. 6d. Schley. Rescue of Greely. Maps and Illustrations, 8vo, I 2s. $6 d$. Schuyler (Eugène) American Diplomacy and the Furtherance of Commerce. 12s. $6 d$.

- The Life of Peter the Great. 2 vols., 8vo, $32 s$. 
Schweinfurth (Georg) Heart of Africa. Three Years' Travels and Adventures in Unexplored Regions. 2 vols., crown 8vo, 155.

Scott (Leader) Renaissance of Art in Italy. 4to, $3^{\mathrm{rs} .} 6 d$.

- Sculpture, Renaissance and Modern. 5 s.

Senior (W.) Waterside Sketches. Imp. $3^{2 \mathrm{mo}}$, $1 s .6 d$., boards, rs.

Shadbolt (S. H.) Afghan Campaigns of 1878-1880. By SYDNEY SHADBOLT. 2 vols., royal quarto, cloth extra, $3 l$.

Shakespeare. Edited by R. GRANT WHITE. 3 vols., crown $8 \mathrm{vo}$, gilt top, $36 \mathrm{~s}$.; édition de luxe, 6 vols., $8 \mathrm{vo}$, cloth extra, 63 s.

Shakespeare. See also WhiTe (R. Grant).

Sidney (Sir Philip) Arcadia. New Edition, $6 s$.

Siegfried: The Story of. Illustrated, crown 8vo, cloth, $6 s$.

Simson (A.) Wilds of Ecuador and the Putumayor River. Crown 8vo.

Sinclair (Mrs.) Indigenous Flowers of the Hawaiian Yslands. 44 Plates in Colour. Imp. folio, extra binding, gilt edges, $31 s, 6 d$.

Sir Roger de Coverley. Re-imprinted from the "Spectator." With I25 Woodcuts and special steel Frontispiece. Small fcap. 4to, 6s.

Smith (G.) Assyrian Explorations and Discoveries. Illustrated by Photographs and Woodcuts, New Edition, demy 8vo, 18 s.

The Chaldean Account of Genesis. With many Illustrations. 16s. New Ed. By Professor Sayce. 8vo, I8s.

Smith (J. Moyr) Ancient Greek Female Costume. I $_{2}$ fullpage Plates and other Illustrations. Crown 8vo, 7s. 6d.

Hades of Ardenne: The Caves of Han. Crown 8vo, Illust., 5 s.

Legendary Studies, and other Sketches for Decorative. Figure Panels. 7s. $6 d$.

Wooing of AEthra. Illustrated. $32 \mathrm{mo}$, Is.

Smith (Sydney) Life and Times. By StuART J. Reid. Illustrated. 8vo, 21s. 
Smith ( $T$. Roger) Architecture, Gothic and Renaissance. Illustruted, crown 8vo, 5 s.

Classic and Early Christian. 5 s.

Smith (W. R.) Lazes concerning Public Health. 8vo, 3Is. 6d.

Spiers' French Dictionary. 29th Edition, remodelled. 2 vols., 8vo, 18 s.; half bound, $21 s$.

Spry (W.J.J., R.N.) Cruise of H.M.S. "Challenger." With with Illustrations. 8vo, 18s. Cheap Edit., crown 8vo, 7s. $6 d$.

Spyri (Foh.) Heidi's Early Experiences : a Story for Children and those who love Children. Illustrated, small post 8vo, $4 s .6 d$.

- Heidi's Further Experiences. Illust., sm. post $8 \mathrm{vo}, 4 s .6 d$. Start (J.W.K.) Junior Mensuration Exercises. 8d.

Stanley (H.M.) Congo, and Founding its Free State. Illustrated, 2 vols., $8 \mathrm{vo}, 42 s$; ; re-issue, 2 vols. $8 \mathrm{ro}, 21 s$.

How I Found Livingstone. 8vo, Ios. $6 d$; ; $\mathrm{cr} .8 \mathrm{vo}, 7 s .6 d$. Through the Dark Continent. Crown 8vo, i2s. $6 d$.

Stenhouse (Mrs.) An Englishwoman in Utah. Crown 8vo, 2s.6d. Sterry (J.Ashby) Cucumber Chronicles. 5 s.

Stevens (E. W.) Fly-Fishing in Maine Lakes. 8s. 6d.

Stewart's Year Book of New Zealand, 18,86-87. 7s. 6d.

Stockton (Frank R.) The Story of Viteau. Illust. Cr. 8vo, $5^{s}$. The Late Mrs. Null. Crown 8vo, 6s.

Stoker (Bram) Under the Sunset. Crown 8vo, 6s.

Stozere (Mrs. Beecher) Dred. Cloth, gilt edges, $3 s .6 d$; boards, $2 s$.

Little Foxes. Cheap Ed., xs.; Library Edition, 4s. 6d. My Wife and $I$. 6s.

- Old Town Folk. 6s.; also 3 s.

Old Town Fireside Stories. Cloth extra, 3s. 6d.

-We and our Neighbours. 6s. 
Stowe (Mrs. Beecher) Poganuc People, 6s. Chimney Corner. Is.; cloth, is. 6 d.

See also Rose I.ibrary.

Stuttfield (Hugh E. M.) El Maghreb : 1200 Miles' Ride through Marocco. 8s. 6d.

Sullivan $(A . M$.) Nutshell History of Ireland. Paper boards, 6d. Sutton (A. K.) A B C Digest of the Bankruptcy Law. 8vo, $3 s$. and $2 s .6 d$.

TAINE (H. A.) "Les Origines de la France Contemporaine."
Translated by John Durand.

I. The Ancient Regime. Demy 8vo, cloth, I6s.

II. The French Revolution. Vol. I. do.

III. Do. do. Vol. 2. do.

IV. Do. do. Vol. 3. do.

Talbot (Hon. E.) A Letter on Emigration. is.

Tauchnitz's English Editions of German Authors. Each volume, cloth flexible, $2 s$. ; or sewed, $1 s_{.} 6 d$. (Catalogues post free.) Tauchnitz(B.) German Dictionary. 2s. ; paper, is. 6d.; roan, 2s. $6 d$.

French Dictionary. 2s.; paper, is. $6 d$. ; roan, $2 s .6 d$.

- Italian Dictionary. 2s.; paper, is. $6 \mathrm{~d}$. ; roan, $2 s .6 \mathrm{~d}$. - Latin Dictionary. 2s. ; paper, is. $6 d$.; roan, $2 s .6 d$. Spanish and English. 2s.; paper, 1s. $6 d$. ; roan, 2s. $6 d$. - Spanish and French. 2s.; paper, 1s. 6d.; roan, 2s. $6 d$. Taylor (R. L.) Chemical Analysis Tables. Is. Taylor (W. M.) Joseph the Prime Minister. 6s. - Paul the Missionary. Crown 8vo, 7s. 6d. Techno-Chemical Receipt Book. With additions by BrannT and WAHL. 10 s. $6 d$.

Thausing (Prof.) Malt and the Fabrication of Beer. 8vo, 45 s. Theakston (M.) British Angling Flies. Illustrated. Cr. 8vo, 5 s. Thomson (Jos.) Through Masai Land. Illust. and Maps. 21 s. 
Thomson (W.) Algebra for Colleges and Schools. With Answers, 5s.; without, $4 s$. $6 d$. ; Answers separate, is. $6 d$.

Thoreau. American Men of Letters. Crown 8vo, 2s. $6 d$.

Tissandier, Photography. Edited by J. Thомson, with Appendix by H. Fox Talbot. Illustrated. $6 s$.

Tolhausen. Supplément du Dictionnaire Technologique. $3^{\text {s. } 6 d .}$

Tristram (Rev. Canon) Pathways of Palestine. Series I., with

Permanent Photographs, 2 vols.,folio, cloth, gilt edges, $3 i s$. 6d. each.

Trollope (Anthony) Thompson Hall. $\mathrm{r}$.

Tromholt (S.) Under the Rays of the Aurora Borealis. By

C. Stewers. Photographs and Portraits. 2 vols., 8vo, $30 s$.

Tucker (W.J.) Life and Society in Eastern Europe. $15^{\text {s. }}$ Tupper (Martin Farquhar) My Life as an Author. I4s.

Turner (Edward') Studies in Russian Literature. Cr. 8vo, 8s. $6 d$.

UNION Jack (The). Every Boy's Paper. Edited by G. A. HENTY. Profusely Illustrated with Coloured and other Plates. Vol. I., 6s. Vols. II., III., IV., 7s. $6 d$. each.

$V^{A L L A N C E}$ (Lucy) Paul's Birthday. 3s. 6d.

Van Kampen (S: R.) Nicholas Godfried Van Kampen: a Biographical Sketch By Samuer R. VAN CAMpen. I4s.

Vasili (Count) Berlin Society. Translated. Cr $8 \mathrm{vo} 6 \mathrm{~s}$. World of London (La Société de Lonidres). Cr. 8vo, 6s.

Victoria (Queen) Life of. By Grace Greenwood. Illust. 6 s. Vincent (Mrs. Howard) Forty Thousand Miles over Land and Water. With Illustrations. New Edti., 3s. $6 d_{\text {. }}$

Viollet-le-Duc (E.) Lectures on Architecture. Translated by Benjamin Bucknali, Architect. With 33 Steel Plates and 200 Wood Engravings. Super-royal 8 vo, leather back, gilt top, 2 vols., $3 l .3$ s. 


\section{BOOKS BY JULES VERNE.}

\begin{tabular}{|c|c|c|c|c|}
\hline LArat Crows 8vo. & $\left\{\begin{array}{c}\text { Containin } \\
\text { and fro } \\
\text { full-page }\end{array}\right.$ & $\begin{array}{l}0600 \mathrm{pp} . \\
0100 \\
\text { rations. }\end{array}$ & Containin & ho \\
\hline WORKS. & $\begin{array}{c}\text { In very } \\
\text { bandsome } \\
\text { cloth bind- } \\
\text { ing, gilt } \\
\text { edges. }\end{array}$ & $\begin{array}{l}\text { In } \\
\text { plainer } \\
\text { binding, } \\
\text { plain } \\
\text { edges. }\end{array}$ & $\begin{array}{c}\text { In cloth } \\
\text { binding, gilt } \\
\text { edges, } \\
\text { smaller } \\
\text { type. }\end{array}$ & Coloured boards. \\
\hline 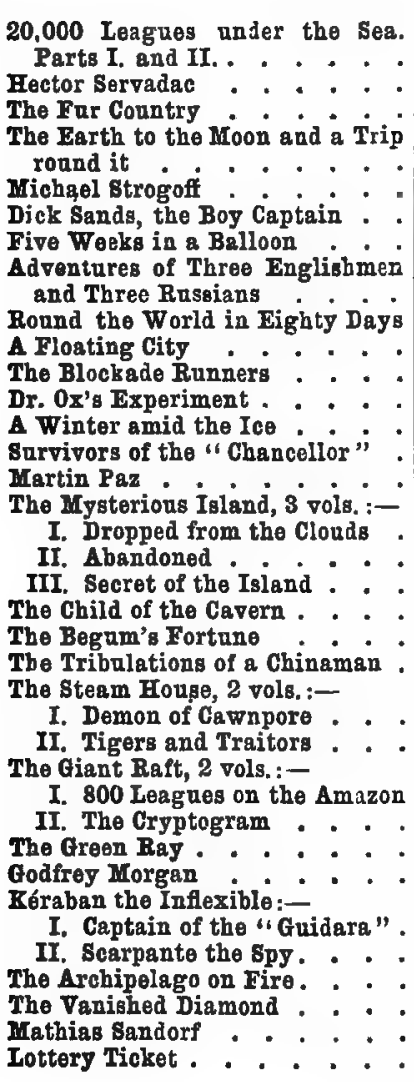 & 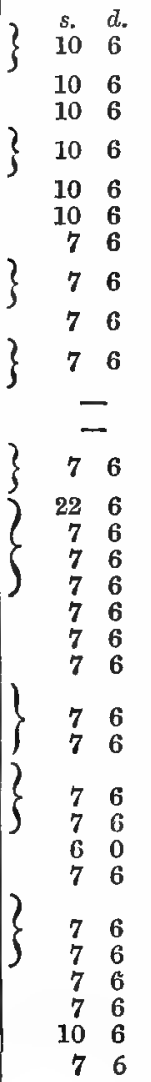 & $\begin{array}{rl}s . & d . \\
5 & 0 \\
5 & 0 \\
5 & 0 \\
5 & 0 \\
5 & 0 \\
5 & 0 \\
3 & 6 \\
3 & 6 \\
3 & 6 \\
3 & 6 \\
& - \\
& \\
3 & 6 \\
10 & 6 \\
3 & 6 \\
3 & 6 \\
3 & 6 \\
3 & 6 \\
3 & 6 \\
3 & 6 \\
3 & 6 \\
3 & 6 \\
3 & 6 \\
3 & 6 \\
5 & 0 \\
3 & 6 \\
3 & 6 \\
3 & 6\end{array}$ & $\begin{array}{cc}s . & d . \\
3 & 6 \\
3 & 6 \\
3 & 6 \\
2 & \text { vols., } \\
2 s . & \text { ea. } \\
3 & 6 \\
3 & 6 \\
2 & 0 \\
2 & 0 \\
2 & 0 \\
2 & 0 \\
2 & 0 \\
2 & 0 \\
2 & 0 \\
3 & 0 \\
2 & 0 \\
6 & 0 \\
2 & 0 \\
2 & 0 \\
2 & 0 \\
2 & 0 \\
2 & 0 \\
2 & 0 \\
2 & 0 \\
2 & 0 \\
2 & 0 \\
2 & 0 \\
2 & 0 \\
2 & 0\end{array}$ & 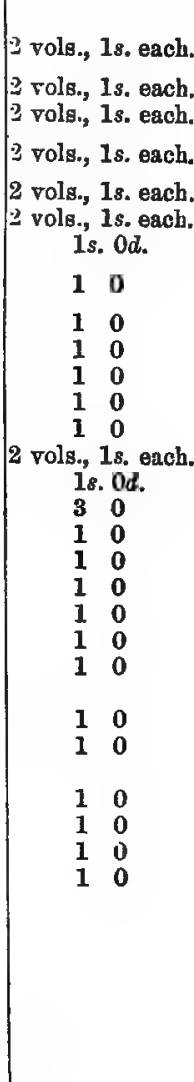 \\
\hline
\end{tabular}

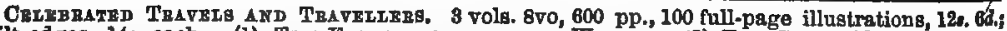

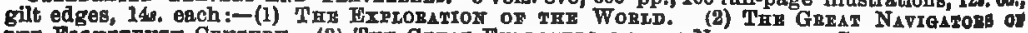

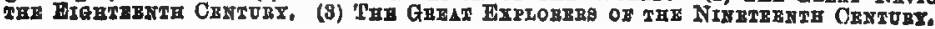


Sampson Low, Marston, \& Co.'s List of Publications.

$W^{A} A H L(W . H$.$) Galvanoplastic Manipulation for the$ Electro-Plater. $8 \mathrm{vo}, 35 \mathrm{~s}$.

Wakefield. Aix-les-Bains: Bathing and Attractions. 2s. $6 d$.

Wallace (L.) Ben Hur: A Tale of the Christ. Crown 8vo, 6 s. Waller (Rev. C. H.) The Names on the Gates of Pearl, and other Studies. New Edition. Crown 8vo, cloth extra, 3s. 6 .

- A Grammar and Analytical Vocabulary of the Words in the Greek Testament. Compiled from Brüder's Concordance. Part I. Grammar. Small post 8 vo, cloth, 2s, 6d. Part II. Vocabulary, $2 s .6 d$. - Adoption and the Covenant. On Confirmation. 2s. 6d. Silver Sockets; and other Shadozus of Redemption.

Sermons at Christ Church, Hampstead. Small post $8 \mathrm{vo}$, 6s.

Walton (Iz.) Wallet Book, CIDI LXXXV. 2 Is.; 1. p. $42 s$. (T. H.) Coal Mining. With Illustrations. 4to, 25 s.

Warner (C. D.) My Summer in a Garden. Boards, Is.; leathereite, is. $6 d$. ; cloth, $2 s$.

Warren (W. F.) Paradise Found; the North Pole the Cradle of the Human Race. Illustrated. Crown 8vo, I2s. 6d.

Washington Irving's Little Britain. Square crown 8vo, 6s.

Watson (P. B.) Marcus Aurelius Antoninus. 8vo, I5s.

Webster. ("American Men of Letters.") I8mo, 2s. $6 d$.

Weir (Harrison) Animal Stories, Old and New, told in Pic-

tures and Prose. Coloured, \&c., Illustrations. 56 pp., 4 to, $5 s$.

Wells (H. P.) American Salmon Fisherman. 6s.

Fly Rod's and Fly Tackle. Illustrated. Ios. $6 d$.

(J. W.) Three Thousand Miles through Brazil. Illus-

trated from Original Sketches. 2 vols. 8vo, $32 s$.

Wheatley (H. B.) and Delamotte (P. H.) Art Work in Porce-

lain. Large 8vo, 2s. $6 d$.

Art Work in Gold and Silver. Modern. 2s. $6 d$. Handbook of Decorative Art. Tos. 6d.

Whisperings. Poems. Small post $8 \mathrm{vo}$, gilt edges, 3 s. $6 d$. White (R. Grant) England Without and Within. Crown 8vo, ros. $6 d$. Every-day English. Ios. 6d. Words, \&c. Fate of Mansfield Humphreys, the Episode of Mr. Washington Adams in England, an Apology, \&c. Crown 8vo, $6 s$. Studies in Shakespeare. 1os. $6 d$. Words and their Uses. New Edit., crown 8vo, 5 s.

Whittier ( $J . G$.$) The King's Missive, and later Poems. I8mo,$ choice parchment cover, 3 s. $6 d$. 
Whittier (J. G.) The Whittier Birthday Book. Uniform with the "Emerson Birthday Book." Square 16mo, very choice binding, 3 s. $6 d$.

- Life of. By R. A. UNDERwood. Cr. 8vo, cloth, ros.6d. - - St. Gregory's Guest, Śc. Recent Poems. 5 s. Williams (C.F.) Tariff Lazes of the United States. 8vo, Ios. 6d. (H. $W$.) Diseases of the Eye. 8vo, $2 \mathrm{I} s$.

Wills, A Fere Hints on Proving, without Professional Assistance. By a Probate Court Official, 8th Edition, revised, with Forms of Wills, Residuary Accounts, \&c. Fcap. 8vo, cloth limp, Is.

Wills (Dr. C. J.) Persia as it is. Crown 8vo.

Willis-Bund $(J$.$) Salmon Problems. 3$ s. $6 d$.; boards, 2s. $6 d$. Wilson (Dr. Andrew) Health for the People.

Wimbledon (Viscount) Life and Times, 1628-38. By C. DalToN. 2 vols., 8vo, 3os.

Winsor (Justin) Narrative and Critical History of America. 8 vols., 30 s. each ; large paper, per vol., 63 s.

Witthaus (R. A.) Medical Student's Chemistry. 8vo, I6s. Woodbury, History of Wood Engraving. Illustrated. 8vo, 18s. Woolsey. Introduction to International Law. 5 th Ed., I8s. Woolson (Constance F.) See "Low's Standard Novels." Wright (H.) Friendship of God. Portrait, \&c. Crown 8vo, 6s. Wright (T.) Town of Cowper, Olney, \&oc. $6 s$.

Written to Order; the Journeyings of an Irresponsible Egotist. By the Author of "A Day of my Life at Eton." Crown 8vo, $6 s$.

YRTARTE (Charles) Florence: its History. Translated by C. B. PItMan. Illustrated with 500 Engravings. Large imperial 4to, extra binding, gilt edges, 63 s. ; or 12 Parts, $5^{s}$, each.

History ; the Medici ; the Hunranists ; letters ; arts ; the Renaissance ; illustrious Florentines; Etruscan art ; monuments; sculpture; painting.

\section{Yondon:}

SAMPSON LOW, MARSTON, SEARLE, \& RIVINGTON, CROWN BUILDINGS, I88, FLEET STREET, E.C. 



